\title{
The character of the New Zealand land snail fauna and communities: some evolutionary and ecological perspectives
}

\author{
Gary M. Barker \\ Landcare Research, Private Bag 3127 Hamilton, New Zealand
}

\begin{abstract}
Alan Solem highlighted the high alpha diversity of land snails that occur in forests of mid-western North Island New Zealand. This paper examines patterns of diversity in land snails across the entire New Zealand archipelago, with a review of the biogeography and composition of taxon groups and with analyses of faunal composition and ecological diversity at national, island and bioregion scales based primarily on collation of museum records. Community composition and structure are also analysed using two extensive series of plot-based assessments. The fauna is primarily Gondwanan in origin, with apparently little influence from establishment of new taxa by chance dispersal since the late Paleocene. It has undergone extensive in situ cladogenesis and speciation that, combined with island biogeographic processes of dispersal and extinction, have resulted in marked intraarchipelago differences in the character of regional species pools. Species richness of communities $\left(0-74\right.$ for $400 \mathrm{~m}^{2}$ plots) was shown to vary substantially within and between bioregions, in part related to patterns of niche availability driven by temporal and spatial heterogeneity in environmental conditions and floristic diversity. It is concluded that in general the New Zealand land snail communities are not in a state of equilibrium, and that the highly dynamic nature of the environment prevents this. Only where regional conditions have favoured persistence of a diversity of forest habitat over several million years is high mean species richness evident at the plot scale. The New Zealand fauna exhibits a strong predominance of minute species with low shell height:diameter ratios. The essentially unimodal dispersion in the shell morphospace contrasts markedly with the bimodal pattern exhibited in many other faunas. If shell shapes define the repertoire of available niches then there is something different about New Zealand in respect to the niches occupied by land snails. However, the shell morphology in the New Zealand representatives of snail families conforms rather closely to that expected within the respective families worldwide, suggesting the morphospace pattern seen in the New Zealand fauna is largely a product of phylogenetic constraint, and has little to do with ecology. The high levels of cladogenesis evident in the New Zealand fauna suggest innovations in ecological niches that are not evident in examination of the shell height:diameter morphospace.
\end{abstract}

Key words: New Zealand, land snails, faunal evolution, spatial diversity

\section{INTRODUCTION}

With the opportunity to work on land snails in various parts of the world, Alan Solem became interested in the mechanisms by which spatial variations in community composition, and species richness as an emergent property, arise and are maintained. In a paper formulating a world model of land snail diversity, Solem (1984) maintained that "the number of species found living together (sympatric diversity) is highest in the mid-western North Island of New Zealand. Favourable and equitable conditions prevailing since the Miocene have contributed to the evolution of a fauna in which 72 species can be microsympatric in a relict patch of forest. Elsewhere in the world, sympatric diversity usually is only five to ten and rarely exceeds 20 species." Solem observed that rather than high levels of sympatry, it is much more common for species to replace each other geographically, in a phenomenon he termed allopatric diversity. This phenomenon was recognised to apply to communities of island and continental areas alike.

Solem's ideas on the patterns of diversity in New Zealand were formulated on the basis of detailed qualitative assessment of communities in remnant forest areas of the Manukau [= Awhitu] Peninsula in the North Island, and by reference to qualitative estimates of regional and local diversity in other parts of the country (Solem et al., 1981; Solem and Climo, 1985). Solem et al. (1981) and Solem (1984, 1990) suggested that the great alpha diversity of 
land snails in the Manukau Peninsula communities owed much to the relative stability of the area and the accumulation in this refugium of species over many millennia, drawn from the surrounding regions. The absence of species endemic to the contemporary Manukau Peninsula suggests that the Peninsula has not been a centre of speciation, though it is possible that such evolutionary events have been masked by dispersal. Solem et al. (1981) hypothesised that accumulation of taxa was favoured by an equable moisture regime and the high quality of the litter space.

Solem's (1984) perspective that land snail communities of forest systems in various parts of the world do approach the richness observed in the Manukau Peninsula communities, motivated a suite of studies in forest systems in various parts of the world. Indeed, despite some variation in sampling methods, the picture emerging is that land snail communities in the Manukau Peninsula may not be unique, with high alpha diversity known from an increasing number of forest systems (e.g., Tattersfield, 1996, and papers in this volume). As acknowledged by Solem (1984), some areas within New Zealand support rather modest land snail diversity and thus in terms of species richness approach conditions more typical of communities worldwide. Clearly, the character of land snail communites varies greatly from region to region, and there remains the need for better understanding of how these variations in community composition arise and are maintained. From a New Zealand perspective, two fundamental questions remain: (i) what are the patterns of diversity across the New Zealand landscape, and (ii) what are the special conditions that allow high alpha diversity at some sites but not at others? An initial exploration of some of the issues as they pertain to New Zealand was presented by Barker and Mayhill (1999), in a regional case study focusing on the Pukeamaru Ecological District. Other recent community-focused studies in New Zealand include Mahlfeld (1990), Brook (1999a-e, 2002) and Brook and Goulstone (1999).

The present paper provides a synopsis of compositional and ecological characteristics of the land snail fauna and communities of New Zealand, based on the understanding that has come from some 170 years of malacological research, and supported by quantitative analyses of data associated with museum collections and extensive series of site studies.

\section{THE CONTEXT: NEW ZEALAND AS AN EVOLUTIONARY ENVIRONMENT}

Because of its relative small land surface area of ca. $270,000 \mathrm{~km}^{2}$, there is a trend for New Zealand to be treated as a single entity in the biogeographic and ecological literature. Myers et al. (2000), for example, recognised New Zealand as one of 25 global biodiversity hotspots for conservation priorities, but this macro-scale perspective fails to acknowledge the considerable variation within the region in terms of both biotic character and conservation status. A consequence of this is that the results of intra-regional studies - such as that of Solem et al. (1981) for land snail communities of the Manukau Peninsula - may be inappropriately generalised to the entire country.

New Zealand is in fact an archipelago that extends over a great latitudinal gradient from ca. $29^{\circ} \mathrm{S}$ to $54^{\circ} \mathrm{S}$ (Figure 1). While the three main islands - North Island, South Island and Stewart Island collectively constitute over $98.5 \%$ of the total area, the archipelago comprises some additional 9,570 smaller islands ranging in size from 94,090 to $<1$ ha. These smaller islands contribute significantly to the environmental and biological diversity of the region.

There is a substantial literature on the geological, evolutionary and ecological history of the New Zealand region. Here I provide a summary, emphasising aspects that are pertinent to our understanding of factors that have shaped the character of the New Zealand land snail fauna and communities.

Palaeomagnetic data and tectonic reconstructions suggest that the main assembly of Gondwana took place around the beginning of the Palaeozoic in near-equatorial latitudes. The supercontinent as a whole drifted into high southern latitudes and was subjected to widespread glaciation by the beginning of the Permian. Break-up of Gondwana started during the Jurassic, ca. 180 million years ago (mya), and continued until the mid Cenozoic. Initial rifting within the supercontinent occurred in the west (between South America and Africa) and in general terms the rifting pattern propagated eastward. By the middle Jurassic-early Cretaceous, a large new landmass had developed that extended far beyond the shorelines of modern New Zealand, northwards at least as far as New Caledonia, westwards to the Lord Howe Rise, eastwards to the Chatham Islands, and southwards to the southern edge of the Campbell Plateau. As rifting had not yet begun on what was to become the site of the Tasman Sea and Southern Ocean, such a landmass was more-or-less continuous with Australia and Antarctica, which at that time were largely emergent. Tectonic spreading began to isolate New Zealand ca. 115 mya. ProtoNew Zealand, comprising a fragment of the eastern Gondwana and accreted terrane(s), broke free. A seaway separated the New Zealand and Australian landmasses by 85 mya, and New Zealand and Antarctica by at least 70 mya, although a substantive more-or-less continuous body of land connected to New Caledonia and further northwest. 


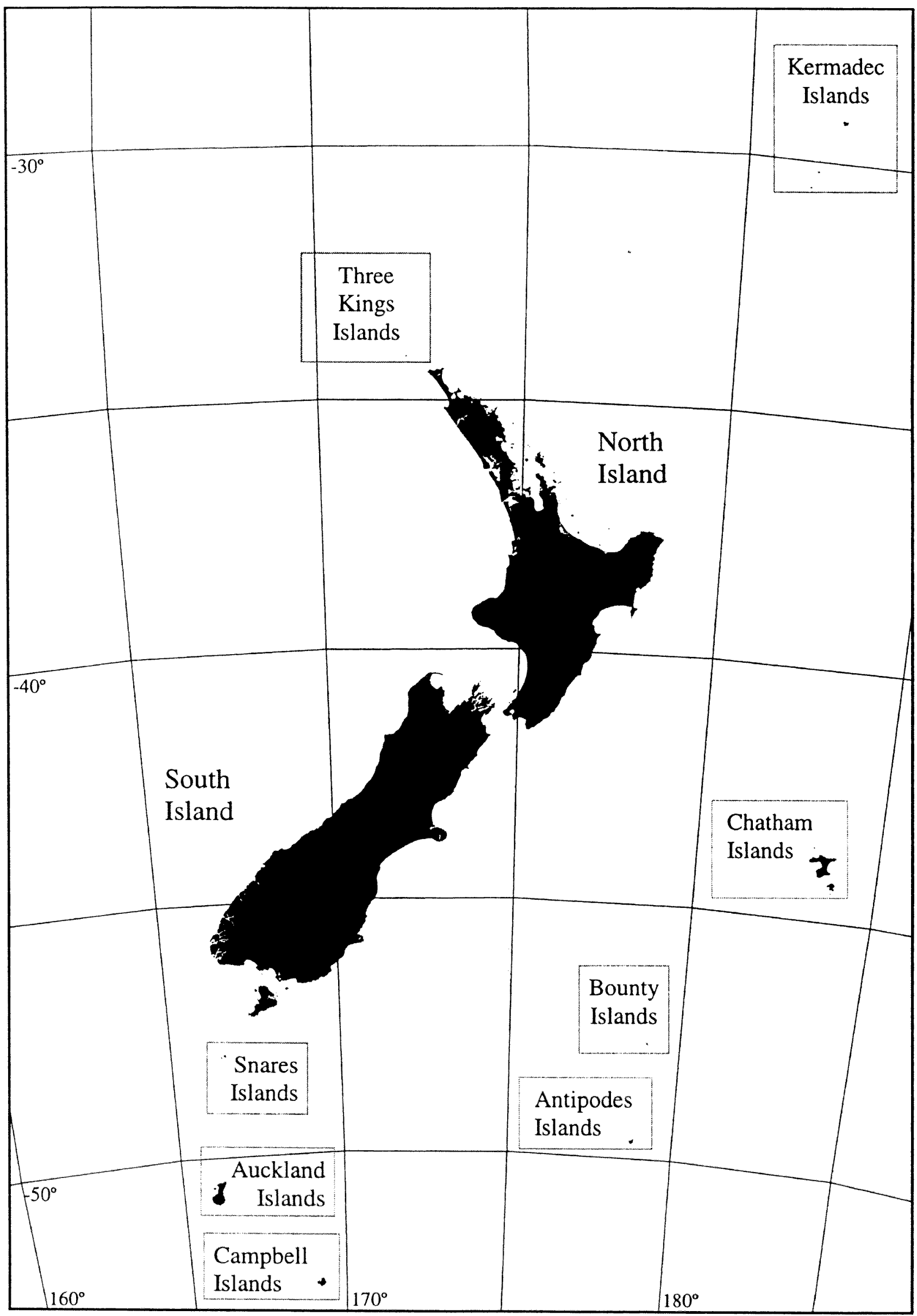

Figure 1 Regional overview map, depicting the main island elements of the New Zealand archipelago. 
During the late Paleocene the Tasman Sea had probably reached its present width $(1,950 \mathrm{~km})$, or slightly more. From this time onwards, oceans became effective barriers to overland routes into or from New Zealand. Throughout the late Cretaceous and early Tertiary steady erosion and marine transgression reduced both the extent and topology of New Zealand's landscape, so that during the late Oligocene-early Miocene only a scattered archipelago of low-lying islands remained. Several authors have highlighted the possible substantive extinction and genetic bottlenecks faced by the flora and fauna resident at that time (Cooper and Cooper, 1995; Cooper, 1998; Hickson et al., 2000), although Lee et al. (2001) point out that the extent of land at the height of the Oligocene transgression was still considerable at around $20,000 \mathrm{~km}^{2}$ and that there is no evidence in angiosperms of significant biotic loss.

Activation of the contemporary Pacific-Australian plate boundary at around 25 mya resulted in the emergence of a latitudinally-elongate landmass during the Miocene, reuniting most or all of the Oligocene islands of the New Zealand region. Tectonic activity intensified throughout the Pliocene (5-2 mya), culminating in the rapid uplift of the axial mountain ranges and at least $480 \mathrm{~km}$ of horizontal displacement on the South Island along the Alpine Fault. Recent molecular phylogeographic studies suggest that many elements of the flora and fauna exhibited elevated cladogenesis and speciation between 5 and 3 mya, coincident with the period of rapid mountain building (e.g. Trewick et al., 2000; Buckley et al., 2001; Trewick, 2001; Trewick and Wallis, 2001; Winkworth et al., 2002; Arensburger et al., 2004). It is likely that for some taxa at least, speciation was mediated by the rapid development of many new habitat types at this time, while for others isolation as a result of mountain barriers may have been important. Earthquakes along the many active faults remain frequent and rates of uplift exceed $4 \mathrm{~mm}$ annually in many parts of the country. New Zealand has been subject to major volcanism, including that in the central North Island throughout the Quaternary to the present. Marine transgressions during the Pliocene reduced and fragmented the land area, with major influence on the evolution of the New Zealand biota (e.g., Cumber, 1962; Climo, 1973, 1975, 1978; Ponder et al., 2003, in respect to land snails).

Within this dynamic tectonic setting, climate has been extremely variable both temporally and spatially. Because of its position in far southern latitudes (ca. $70^{\circ} \mathrm{S}$ ), cool temperature climates predominated in Cretaceous New Zealand (Mildenhall, 1980). Gondwanan floras of the Jurassic and Cretaceous (times immediately preceding and during break-up) were dominated by araucarian and podocarp conifers and a range of enigmatic seed-fern groups. Angiosperms became established in the region as early as Aptian times (before the final break-up) and steadily diversified during the late Cretaceous, apparently at the expense of many seed-fern groups. Consistent with the global pattern, non-flowering plants dominated the New Zealand vegetation during the early Cretaceous. As Antarctica moved southwards, Australia and New Zealand moved northwards. Thus New Zealand's geographic position changed from a centre around $50^{\circ}-45^{\circ} \mathrm{S}$ latitude in the Paleocene to $45^{\circ}-40^{\circ} \mathrm{S}$ in the late Eocene. Extended periods of warming in the Eocene and early Miocene were associated with development of angiosperm-dominated assemblages, including wet sclerophyll forests dominated by now locallyextinct Eucalyptus. These palynofloras were rather uniform in composition. From the Miocene, progressive development of environmental gradients resulted in increasing regional differentiation in the vegetation (Mildenhall, 1980; McGlone, 1985). Cool temperature conditions were widespread by the late Miocene and continued throughout much of the Pliocene, before deteriorating further with the onset of glaciation ca. 2.5 mya. In contrast to the relative stability of early and mid Cenozoic, the ecological conditions prevailing from the mid Miocene through the Pliocene resulted in substantial extinction in the New Zealand flora, with loss of more than 10 percent of the plant families and 30 percent of the plant genera (Lee et al., 2001).

Ice-age New Zealand (2.5 mya to 14,000 years ago) experienced repeated glacial-interglacial cycles that were characterised by dramatic climatic fluctuations and further major changes in the vegetation (McGlone et al., 1993; Newnham et al., 1999). Ecological responses involved readjustments in species ranges in response to extreme climatic conditions of low temperature and aridity (Mildenhall, 1980; Pole, 1994). Local assemblages were in some areas extirpated by the direct action of glaciers. Thus, during glacial maxima, trees were confined mostly to the lower latitudes, although evidence for closed forests is equivocal. Extensive grasslands and shrublands occurred, strongly dominating lands free from ice south of ca. $38^{\circ} \mathrm{S}$. During interstadials and interglacials, woody plant species spread rapidly from refugia, often reestablishing forests even in the southernmost areas (McGlone, 1985; Markgraf et al., 1995). The inferred rapid rate of reforestation of most of New Zealand following the last glacial, and during interstadial periods within it, indicates expansion from widely distributed ecological refugia, rather than migration on a broad front from the northern refugia (McGlone, 1985; Ogden, 1989; Ogden et al., 1992; Newnham et al., 1999). The modern existence of 
alpine-adapted species, despite the short history of this environment in New Zealand, has been attributed either to colonisation of New Zealand by cold adapted taxa from elsewhere, or to radiation and adaptation in situ during the Pleistocene. Recent molecular evidence from plant taxa indicates that both explanations can apply, as in some cases dispersal of progenitors to New Zealand was recent and resulted in rapid radiation of alpine taxa (Wagstaff and Garnock-Jones, 1998; Breitwiesser et al., 1999; Wagstaff and Wardle, 1999). Studies on alpine fauna (Trewick, 2001) generally point to in situ maintenance of at least some of the lineage diversity established prior to Pleistocene glaciation. The geophylogenetic structure of lineages suggests survival in a mosaic of ecological refugia, rather than one or few regional refugia (Trewick, 2001). Late Tertiary and Quaternary glaciation played an important role in formation of many modern landforms, with extensive glacial moraine valley systems and alluvial plains. With lowering of sea-levels, there were considerable, albeit transient, increases in land area and unification of islands as the coastline advanced down the continental shelf.

The final glacial retreat began around 14,000 years ago and was followed by a period of warm, moist conditions. The cooler, drier and more variable contemporary climate conditions were established around 7,000 years ago (McGlone, 1985). The initial re-establishment phase was evidently dominated by coniferous forest, with the angiosperm broadleaf forest only now gaining the ascendancy (Robbins, 1962).

A dominating influence is the axial mountain ranges that, since their establishment in the Pliocene, have intercepted rain-bearing westerly winds which have predominated over the southern hemisphere mid latitudes since the mid Miocene. This interception continues to result in very steep rainfall gradients between the wet western flanks of the axial ranges and the "rain-shadow" areas to the east. Northern and eastern districts have also long been subject to moist northerly airstreams, associated with complex depressions and tropical cyclones, causing high intensity or prolonged rain. The tree line varies with latitude from about 1,500 $m$ in the central North Island to near sea level in the Campbell Islands. The nival zone is rather restricted in the North island, but extensive in the South Island.

At least $75 \%$ of New Zealand's land surface had become forested about 800 years ago, when human occupation of the archipelago was likely established. Non-forested areas were predominantly low- to mid-elevation and alpine tussock grasslands, alpine herbfields, coastal turfs and cliffs, coastal dunelands, and a variety of wetland systems. Associated with climatic- and/or edaphic-induced local depressions of the tree line was a mixed subalpine scrub in which woody Compositae and Epacridaceae predominated. Lowland climax communities in semi-arid regions often comprised shrublands and tussock grasslands, generally dominated by Leptospermum in Myrtaceae and Festuca and Poa in Graminae, respectively. Extensive areas on the mountains, above about 950 $\mathrm{m}$, were occupied by snow tussock grasslands in which Chionochloa grasses to $2 \mathrm{~m}$ tall predominated. The snow tussock grasslands usually gave way at higher altitudes to a dwarfed vegetation of small herbs, short grasses, and semi-woody plants, many of cushion form. Although forest vegetation dominated the pre-human landmass, just $25 \%$ of the flora was woody (Druce, 1993).

The contemporary forests are either hardwood or mixed coniferous-hardwood. The conifers are chiefly Podocarpaceae and, in the northern districts, Araucariaceae. Among the hardwood families, Fagaceae (with four species of Nothofagus) strongly dominate the tree communities over extensive areas, often as monotypic stands. Fagaceae occupy the colder and/or drier areas while the conifers, in association with hardwoods, tend to characterise those less austere. However, there are some anomalies, attributed to incomplete readjustment following restrictions in distribution during the Pleistocene (Wardle, 1963). The New Zealand Nothofagus forests are structurally similar to the temperate deciduous forests of the northern hemisphere. While both evergreen and deciduous strategies are represented in the genus, all New Zealand Nothofagus species are evergreen. However, some of the New Zealand Nothofagus species might well be described as spring deciduous, as it is usually at or not long after the new season's leaves appear that the previous season's leaves are shed (Russel, 1936; McGlone, 2004). The other hardwood forests, and those of mixed conifers and hardwoods, are characterised by: evergreen canopy and emergent tree species; a dense undergrowth of subcanopy shrubs, groundcover and lianes, including often a great abundance of tree ferns; often great profusion of bryophytes and both herbaceous and woody epiphytes; damp and deep humus layer in the soil; and significant mass of rotting woody debris on the forest floor (Oliver, 1930; Dawson and Sneddon, 1969; Dawson, 1986; Wardle, 1991; Stewart and Burrows, 1994). The tree flora comprises about 125 species, but tree richness in hardwood and mixed coniferous-hardwood forests rarely exceeds 10-12 species at individual sites. Nonetheless, the forests often have high fractual diversity, with dense understories and an abundance of lianes and epiphytes. Compared to Nothofagus forests, the litter and humus of mixed coniferous-hardwood forest is shallower (ca. 7-10 cm compared to $15 \mathrm{~cm}$ ) and less 
less acidic ( $\mathrm{pH}$ ca. 5.9 compared to $\mathrm{pH} 4.5-4.7$ ) (Moeed. and Meads, 1985). Annual litterfall estimates in New Zealand forests range from 4,500 to $7,500 \mathrm{~kg} / \mathrm{ha}$, and are thus similar to other temperate forests (Bray and Gorham, 1964).

Most areas of New Zealand forest cannot be older than ca. 10,000 years, as they have re-established on lands affected by glacial ice and harsh climates during the Otiran Glaciation. Even in those areas with more or less continuous forest during the last glacial maxima, there have been substantial changes in forest composition over the last few millennia as climate has fluctuated. The forests have and continue to be subjected to frequent disturbance, with windthrow, mass movements associated with avalanches and rainfall- and earthquake-induced landslides, and lightning-induced fire. The prevalence and predominantly local scale of the disturbances leads to regeneration gaps localised in space and time, the imprint of which is seen in the mosaics of mixed age and species that are a feature of many forest areas (Shaw, 1983; Ogden 1985; Ogden et al., 1991). The character of regeneration succession varies with the nature and severity of the disturbance, with de-vegetated sites often colonised by myrtaceous Leptospermum and Kunzea. Canopy gaps created by tree fall are often colonised by even-aged seedling cohorts of the resident canopy species. In highly unstable systems, the vegetation may be dominated by floralistically-rich scrublands. Studies of recent disturbances - such as volcanism in the central North Island (Clarkson et al., 1986; Rogers and McGlone, 1989) - indicate that forests are able to re-establish within $200-400$ years. Studies of chronosequences show that, in the absence of disturbance, forests undergo a gradual decline as essential nutrients (especially phosphorus) become increasingly sequestered in the woody biomass and thus become unavailable for new vegetative growth (Warde et al., 2004).

While the disharmonic nature of the New Zealand fauna is widely acknowledged, there is presently little understanding of its evolutionary consequences. Cretaceous non-marine environments in New Zealand supported a diverse assemblage of vertebrates, including ornithischian and saurischian dinosaurs, rhynchocephalian, crocodilian and squamatan reptiles, anuran amphibians, and a range of primitive birds. However, the modern biota of New Zealand landbased ecosystems, forested and non-forested alike, has evolved largely in the absence of serpentes and mammals - two groups that have had major impacts on the development of ecosystems in other parts of the world, and include numerous species with malacophagous feeding habits (Allen, 2004; Laporta-Ferreira and Salomão, 2004). Mammals and Serpentes evidently evolved in the Mesozoic and thus pre-date the breakup of Gondwana (Hedges $e t$ al., 1996). There is no evidence for Serpentes ever having been a component of the New Zealand biota. The only mammals indigenous to contemporary New Zealand are three species of bat. Other vertebrate groups that include recognised land snail predators, such as caudatan and gymnophionan amphibians, have also been notably absent from New Zealand. Thus the vertebrate complement of the New Zealand terrestrial biota has been dominated by birds and saurian reptiles, with less diverse components of rhynchocephalian reptiles, anuran amphibians, and bats (Bull and Whittaker, 1975). Among New Zealand invertebrates there is remarkably low diversity of malacophagous predators. Among Coleoptera with potential importance for predation on land snails (Symondson, 2004), only Carabidae are speciose. Drilidae, Lampyridae and Silphidae are entirely absent from the coleopterous fauna. In Diptera, the families Calliphoridae, Phoridae, Sacrophagidae and especially Sciomyzidae include important predators and parasitoids of land snails in many areas of the world (Coupland and Barker, 2004; Barker et al., 2004), yet are poorly represented in New Zealand, as are ants (Formicidae) among Hymenoptera.

\section{MATERIALS AND METHODS}

\section{Study area and intra-archipelago biogeographic provinces}

The study area encompassed the entire New Zealand archipelago (Figure 1). In addition to recognition of islands as geographic units, a classification was adopted to address intraarchipelago variation in biogeographic processes and land snail assemblages. Bioregions (Figure 2) were defined in ArcGIS v8.2 geographic information systems (GIS) software as the spatial intersections of digital representations of geological attributes especially terranes (Adams, 1979; Stevens, 1980; Korsch and Wellman, 1988; Cooper, 1989; Kear, 1993; Mortimer et al., 1999; Sutherland, 1999; King, 2000; Pickard et al., 2000), displacement along the Alpine Fault (Wellman, 1985; Korsch and Wellman, 1988; Smale, 1991; Sutherland, 1999), uplift rates (Wellman, 1979), and Pleistocene to Recent alluvial deposition (Korsch and Wellman, 1988). Regional disturbance histories such as Pliocene to Recent volcanism (Froggatt and Lowe, 1990), Oligocene and Pliocene marine transgressions (Suggate et al., 1978; Cooper and Milner, 1993; Lewis et al., 1994; Cooper and Cooper, 1995; King, 1998), and late Pliocene to Pleistocene glaciation (McGlone, 1985, 1997; McGlone $e t$ al., 1993) and the associated changes in degree of geographic isolation with variations of the coastline on the continental shelf also serve to differentiate bioregions. 


\section{Data sources}

\section{Faunal composition at macro-scales}

Estimates of the composition of the snail fauna at national, island and bioregional scales were based on museum collections - principally Museum of New Zealand Te Papa Tongarewa (NMNZ) and Auckland Institute and Museum (AIM), supplemented by records derived from community sampling at sites (see below). Distributional records of species supported by map coordinates, or with good locality data from which to derive robust map coordinates, were compiled in a relational database. Using GIS software, these records were digitally mapped and variously sorted and summarised according to the geographic units of interest.

A hierarchical classification of the bioregions was implemented from a bioregion $x$ species-presence matrix. The unweighted pair group arithmetic centroid (UPGMC) clustering strategy (Sneath and Sokal, 1973) was applied using the PATN software package (Belbin, 1995) to implement agglomerative hierarchical grouping of bioregions, with the Czekanowski (1913) metric as the measure of compositional distance.

\section{Community Assessment}

\section{Quantitative sampling based on standardised search effort (SSE)}

Assessments of community composition were made for plots across the full geographic breadth of New Zealand in environments ranging from coastal dunes, cliff-face shrublands and forests, through lowland and montane forests and scrublands, to subalpine grasslands and herb-fields. Many of the assessments were made by the present author. However, additional assessments by other malacologists working in New Zealand were included, with data drawn from publications (Gardner, 1977; Mayhill, 1981; Solem et al., 1981; Mayhill and Goulstone, 1986; Goulstone, 1990; Roscoe, 1992; Goulstone et al., 1993; Barker and Mayhill, 1999; Brook, 1999a-e, 2002; Brook and Goulstone, 1999; Mahlfeld, 2000), unpublished reports (Goulstone, 1976, 1977a,b, 1978, 1979a,b, 1980a-c 1981a,b, 1982, 1983, 1984a,b, 1986, 1991; Gardner and Goulstone, 1977; Mayhill and Broomfield, 1982; Broomfield, 1983; Mayhill and Goulstone, 1984; Mayhill, 1985; Mason, 1988; Mahlfeld, 1990; Barker and Mayhill, 1996), and unpublished data made available by P.C. Mayhill, J.F. Goulstone, F.J. Brook, D.J. Roscoe, G.R. Parrish and others. Generally the plots were undefined in that the boundaries were not scribed by a tape measure or string line, but generally each comprised an area ca. $20 \times 20 \mathrm{~m}$ in extent. Similar search effort was applied per plot. Individual live snails or empty shells were gathered from the ground and arboreal leaf and wood surfaces. Snails were, however, primarily sampled by collections of litter and humus from micro-sites favourable for live animals or the accumulation of dead shell assemblages. For forests these micro-sites generally comprised the base of trees or rocks, rock ledges, under and on logs and other coarse woody debris, and crevices amongst talus boulders. For open sites collections of litter and humus were focused in and around the base of tussock grasses, and loose soil and leaf litter accumulations under or adjacent to shrubs, cobbles and boulders. These collections were supplemented by 'spooning' fine particulate humus and associated micro-snails from small crevices on rock faces and ledges, on tree trunks, under bark, in tree boles, etc. Collectively this litter and humus material amounted to 2-4 litres and, on return to the laboratory, was slowly and completely dried in a warm room or oven at $50-70^{\circ} \mathrm{C}$. Dried samples were processed by searching under a stereomicroscope, often with prior partitioning by dry sieving.

The location of each plot was recorded as New Zealand Metric Grid (NZMG) coordinates. Material from these plots is housed in part in the collections of NMNZ (e.g., P.C. Mayhill Collection; D.J. Roscoe Collection) and AIM (e.g., J.F. Goustone Collection) and in various private collections.

Rarefaction analyses were used to identify those plots for which sampling intensity was sufficient to provide reliable estimates of species richness $(S)$. True species richness was estimated as $S=S_{\text {observed }}+$ $L[(N-1) /(N)]$, where $L$ is the number of species that were represented by only one individual, and $N$ is the total number of individuals in the plot sample. A total of 2,485 plots were identified as suitable for quantitative analyses. While Athoracophoridae were often found in plots during assessment of land snail communities, these slugs were excluded from analyses at the plot scale as the sampling methods did not provide robust assessment of presence or abundance.

\section{Quantitative sampling based on frame samples plus standardised search effort (FESSE)}

Over a period spanning 15 years, but especially 1995 to 2003, a total of 931 plots were sampled for land snails to provide more quantitative estimates of the structure of litter-dwelling communities. The location of each $20 \times 20 \mathrm{~m}$ plot was recorded on NZMG coordinates. Documentation of the communities from each plot was accomplished by the combination of two sampling strategies: (i) Defined area sampling by gathering litter and humus from eight circular $0.086 \mathrm{~m}^{2}$ frames randomly placed on the forest floor. On return to the laboratory, the litter was oven dried at $50^{\circ} \mathrm{C}$ and sieved. All litter retained by a $5 \mathrm{~mm}$ mesh sieve was searched by eye for larger shells, and the 
material passing through the $5 \mathrm{~mm}$ mesh was searched under a stereomicroscope; (ii) General collection by hand, as described above for the SSE sampling. The material from these plot studies is housed primarily in the private collection of the author, with some material in NMNZ and AIM.

During the field work the character of the vegetation at each site was recorded by visual assessment: (i) the plant species which constituted $20 \%$ or more-of the-eanopy -i.e. whose crowns were $50 \%$ or more exposed to the sky - were noted; (ii) the height of the canopy tier was estimated on a scale of 1 to 25 (approximating $0.5 \mathrm{~m}$ height intervals); and (iii) an index of floristic diversity (FD) was calculated as

$$
F D=\frac{1}{n} * \sum_{i=1}^{T} \sum_{i=1}^{S}(C i * W t)
$$

where $T$ is the tier class, $S$ is the species of vascular plants within a tier class, $\mathrm{C} i$ is the cover value for species $i, W t$ is the weighting applied to species within the tier class, and $n$ is the number of tiers. The tier classes recognised, and the weights applied a posteriori, were: (a) trees, with stature $>3 \mathrm{~m}$ in height (weighting 600), (b) shrubs $>2 \mathrm{~m}$ in height (weighting 200), (c) shrubs and tall grassland tussocks $0.3-2 \mathrm{~m}$ in height (weighting 50), (d) ground cover and short grassland $<0.3 \mathrm{~m}$ in height (weighting 20), (e) epiphytes (weighting 50), and (f) woody lianes (weighting 100). Weightings were intended to approximate the relative tier contributions to above-ground biomass and litter fall. For purposes of analyses, the floristic diversity index was range standardised between 0 and 10 across the entire plot data set. Litter was collected from five circular $0.086 \mathrm{~m}^{2}$ frames from each plot, pooled and dried $\left(80^{\circ} \mathrm{C}, 24 \mathrm{~h}\right)$ to determine the total mass of litter on an areal basis.

\section{Taxonomy and nomenclature}

Species identifications were made with reference to the New Zealand malacological literature and the collections at NMNZ and AIM. The nomenclature adopted for undescribed taxa follows that of Spencer et al. (2005) where a numeric species tag is supported by the registration number of a voucher at NMNZ or AIM.

\section{Data analyses}

\section{Species-island area relationships}

Species richness $(S)$ - area $(A)$ relationships were examined using the power function model $S=c A^{z}$, with logarithmic transformations to estimate the equation parameters for purposes of computing $c$ and $z$. Island and bioregion areas were determined in GIS coverages. The land snail assemblage and thus species richness of each island or bioregion was determined by overlay in GIS of the species locality records on the digital depiction of the New Zealand region at a spatial resolution of $25 \mathrm{~m}$. To address environmental heterogeneity effects, the power model was fitted by substituting area by numbers of environment types. Similarly, to address solar energy inputs, models included mean annual temperature as a predictor variable. The mean annual temperature for each island and bioregion was. estimated ...as the average of $100 \mathrm{~m}^{2}$ grid cells in a digital surface of estimated temperatures. Climate estimates for grid cells were derived from $100 \mathrm{~m}$ resolution surfaces fitted by thin-plate spline regressions that use information about the climate (30 year period 1950-1980), and location and elevation of meteorological stations (Leathwick and Stephens, 1998; Rutledge and Wilson, 2003). The number of environment types was determined by spatial overlay of the digital depiction of islands and bioregions on a digital depiction of Land Environments of New Zealand (LENZ) (Leathwick et al., 2002a,b, 2003). Briefly, LENZ is a hierarchical classification of grid cells, based on their environmental profile, to define areas of similar environmental character. The classification process by which LENZ was developed involved firstly determining environmental distances between grid cells in a digital representation of the New Zealand landscape, using the Gower (1971) metric. The hierarchical classification was then implemented using the flexible unweighted pair group arithmetic average (UPGMA) strategy for agglomerative clustering (see Leathwick et al., 2002a, 2003 for further explanation of methods). For the present analyses, the Level IV classification was adopted, which enabled identification of 500 environment types within the area extending from Three Kings Islands through North, South and Stewart Islands, and numerous adjacent smaller islands. For the present work, this classification scheme was extended to the Kermadec Islands, Chatham Islands and the Subantarctic Islands by relating the environmental profiles of areas within these island systems - primarily delineated on the basis of soil unit boundaries and elevation contours - to that of the environmental centroids for each of the 500 Level IV LENZ environments. If environmental distances, measured in the Gower metric, exceeded the 0.0775 threshold, the areas were assigned to a new environmental unit. Through this process, a total of 522 environmental types were identified for the New Zealand archipelago.

\section{Niche breadth of species}

Locality data were overlaid on a 25 m-resolution GIS digital elevation model of New Zealand to derive estimates of the geographic range of each species. Geographic range was defined as $\sqrt{ }$ 
[(maximum range in Eastings $)^{2}+$ (maximum range in Northings) ${ }^{2}$ ], where eastings and northings were in NZMG. The locality data were also overlaid on $100 \mathrm{~m}$ resolution GIS grid coverages of climate (Leathwick and Stephens, 1998; Rutledge and Wilson, 2003) and soils data (New Zealand Land Resource Inventory (NZLRI)) to estimate attributes of sites at which species were recorded. Climate niche was then estimated as the range (maximum minus minimum) of values averaged across annual rainfall, annual mean temperature, mean minimum temperature of the coldest month (July), mean annual ratio of monthly rainfall to PET, and annual water deficit as the accumulated monthly differences between rainfall and evaporation. Environmental niche was similarly estimated by combining the above climatic factors with soil acidsoluble phosphorus (5 class categorical scale, based on mean $\mathrm{mg} / 100 \mathrm{~g}$ values for soil units), soil exchangeable calcium (4 class categorical scale, based on mean $\mathrm{mg} / 100 \mathrm{~g}$ values for soil units), soil age (2 class categorical scale, separating Recent or raw soil orders from older, weathered soils orders), soil drainage (5 class categorical scale), and soil particle size (4 class categorical scale, based on mean values in millimeters for soil units) (see Leathwick et al., 2002a for further explanation of climate and soils variables).

\section{Shell morphospace}

Morphospace was defined from shell height $(\mathrm{H})$ and shell diameter (D). The ratio H:D provides the spire index (Cain, 1977). For New Zealand species, measurements were made on voucher specimens, using either an ocular micrometer or manually operated callipers. The measurements of shell morphology for extralimital taxa were derived similarly from specimens in various museum collections or, in the absence of the latter, from illustrations in the malacological literature. These measurements represent the upper limits of shell size in the species, ignoring cases of gigantic individuals. Periostracal outgrowths of the shell were not included in the measurements.

Two analyses were performed at the faunal level. Firstly, the total morphospace potentially available to the New Zealand fauna was defined as the morphospace circumscribed by the global extremes of shell morphologies in the $\mathrm{H}$ and $\mathrm{D}$ dimensions. The morphospace delineated by the New Zealand fauna, was then expressed as a proportion of the total. Secondly, the shell morphospace of New Zealand species was contrasted with that circumscribed collectively by all described members of the same family elsewhere in the world. For the families Charopidae, Punctidae and Rhytididae, where there was sufficient richness ( $>60$ species) for robust model fitting in both the New Zealand and extralimital faunas, the dispersion in $\mathrm{H}: \mathrm{D}$ morphospace was evaluated quantitatively using Ripley's (1976, 1981) K(t)-function, implemented with S-Plus software (Venables and Ripley, 1997). The results are presented as the difference between the observed $K(t)$-function for the New Zealand members and the $K(t)$-function for the extralimital members of the same family. The $95 \%$ confidence envelope around the difference was based on 1,000 Monte Carlo permutations. The null hypothesis is that there is no difference between New Zealand and extralimital faunas in the expected number of species located within each of a series of $t$-distance intervals from an arbitrary point in the morphospace being evaluated.

At the community level, all shells recovered from the F\&SSE samples were measured, thus enabling calculation of abundance-weighted means and coefficients of variation of shell size and $\mathrm{H}: \mathrm{D}$ ratios.

\section{Rank abundance diversity}

Relative abundance-species-rank-order (relativeabundance distributions, RAD) curves (Whittaker, 1965) were constructed for plots subjected to SSE and F\&SSE sampling regimes, by plotting the $\log _{10}$ percentage relative abundance for each species in sequence from the most to the least dominant. These RAD curves were compared qualitatively across spatial scales. Quantitative comparisons of community structure at the plot scale were made using Whittaker's (1972) equitability index $E c=S_{p} /$ $\left(\log C_{1}-\log C_{n}\right)$, where $S_{p}$ is the total species richness at the plot level, and $C_{1}$ and $C_{n}$ the abundances for the most and least numerous species, respectively. $E c$ is a crude measure of slope and refers to the average number of species per logcycle of abundance - steep slopes have few species per log cycle and low values for $E c$.

\section{Rate of site occupancy by species}

Site occupancy within each bioregion was calculated as the mean proportion of plots occupied per species. The variance about the mean number of plots occupied per species was taken as indicative of geographical patterning in species distributions. Actual variances of plots per species were expressed as a proportion of the maximum possible for the observed values of total richness in the set of sampled plots and species per plot (Cameron, 1992, 1995).

\section{Additive partitioning of diversity}

Species diversity estimates from hierarchically nested samples were additively partitioned to break down total diversity $(\gamma)$ into a and $B$ components (within and among samples) (Wagner et al., 2000; Veech et al., 2002; Gering et al., 2003). The total diversity in a collection of samples, $\gamma$, was partitioned into the average diversity within samples $(\alpha)$ and among samples (B) so that $\gamma=\alpha+$ 
$B$, and $B$ diversity calculated from $B=\gamma-\alpha$ (Wagner et al., 2000). This partitioning was extended across multiple scales. Let $\alpha_{i}$ represent the average diversity found within samples at each level $i$. The diversity components were calculated as $\beta_{m}=\gamma-\alpha_{m}$ at the highest sampling level and $\beta_{\mathrm{m}}=\alpha_{i+1}-\alpha_{i}$ for each lower sampling level. Then, the additive partition of diversity was $\gamma=\alpha_{i}+\left(B_{i}+\beta_{i}+\ldots \beta_{m}\right)$. Any measure of diversity can be additively partitioned if $\gamma \geq \alpha$, a condition that ensures that $\beta$ is non-negative (Lande, 1996). For the present analyses, additive partitioning was performed on species richness only.

PARTITION software (Crist et al., 2003) was employed for the analyses. Data from the SSE sampling were used to determine the contributions of diversity due to bioregions, environment types (LENZ Level IV), and plots. The data from F\&SSE sampling were used first to partition diversity into components associated with bioregions, environment types, plots and frames. A variant of the above treatment of the F\&SSE data was also adopted, whereby diversity was partitioned into components associated with bioregions, floristic diversity groups, plots and frames, where frames and plots were hierarchically nested within 10 equal-interval groups based on the floristic diversity index.

I used PARTITION to apply the randomization routines of Crist et al. (2003) for testing null hypothesis that the observed components of $\alpha$ and $\beta$ diversity would be expected by random distribution of individuals among samples. The randomization procedure uses a reshuffling algorithm to place individuals in samples randomly while preserving the original species abundances and sample-size distributions.

\section{Ordination}

Discrimination of plots according to attributes of the land snail communities was examined by semistrong-hybrid (SSH) multidimensional scaling (MDS) ordination (Faith et al., 1987; Belbin, 1991) as implemented in PATN. Data were entered as species presences/absences for the SSE sampling, and as species abundances for F\&SSE sampling, with the latter restricted to snails found in the litter collected from frames. UPGMA clustering was used to implement agglomerative hierarchical grouping (Sneath and Sokal, 1973) of plots, with the Czekanowski (1913) metric as the measure of compositional distance for the SSE data set, and the Bray and Curtis (1957) metric for the F\&SSE data set. The problem of local optima was minimized in the analysis by using 10 random starting configurations and selecting the MDS solution that yielded minimum stress (Faith et al., 1987).

Principal Axis Correlation (PCC) analyses were performed in PATN to examine directionality and correlation of vectors describing gradients in the measured biogeographic and environmental variables. For the SSE data, the PCC analysis relied on environmental and biogeographic parameters derived entirely from overlay of site geographic coordinates on digital spatial data. The parameters used were (i) bioregion; (ii) maximum age (in millions of years) for residency of the common ancestors, taken from information on the geological history of land parcels making up bioregions (also see Cooper, 1998); (iii) climate parameters, including annual rainfall, annual solar radiation, annual mean temperature, mean minimum temperature of the coldest month of winter (July), the ratio of rainfall to PET, and annual water deficit, each estimated from a $100 \mathrm{~m}$ resolution surface (see above); (iv) soil parameters, including acid-soluble phosphorus, exchangeable calcium, age, particle size and drainage and total nitrogen from NZLRI; and (v) attributes of vegetation cover, including tree species richness, and abundances (stems per hectare) of Fagaceae (summed over 4 species in the genus Nothofagus), Myrtaceae (summed over 6 species in Kunzea, Leptospermum, Metrosideros and Syzygium) and Podocarpaceae (summed over 12 species in Dacrycarpus, Dacrydium, Halocarpus, Lepidothamnus, Manoao, Podocarpus and Prumnopitys) estimated from $25 \mathrm{~m}$ resolution spatial predictions using generalised additive regression models (Leathwick, 2001; J. Overton and C. Dischinger, unpubl.). In the PCC analysis for the ordination of the F\&SSE data, the above environmental parameters were complemented with environmental data collected on-site, including the index of floristic diversity, and litter mass, in grams dry weight $/ \mathrm{m}^{2}$.

\section{Enviromental and spatial correlates with alpha diversity}

Partial regression analyses were employed to partition the variation in species richness at the plot scale into four components: (a) the component of the spatial variation in richness that is not shared with the environmental variables; (b) spatial structuring in richness data that is shared with the environmental variable data; (c) the component of the spatial variation in richness that can be explained by the environmental variables independent of any spatial structure; and (d) unexplained (residual) variation (Legendre and Legendre, 1998). The spatial component of richness was modelled using a third-order polynomial of the form

$$
\begin{gathered}
f(x, y)=b_{0}+b_{1} x+b_{2} y+b_{3} x^{2}+b_{4} x y+b_{5} y^{2}+b_{6} x^{3}+ \\
b_{7} x^{2} y+b_{8} x y^{2}+b_{9} y^{3}
\end{gathered}
$$

where $x$ and $y$ represent eastings and northings in NZMG, respectively (Cartesian NZMG coordinates were analysed to preclude biases originating from use of polar-coordinate latitude and longitude projection). This expression is sufficient to extract 
any linear gradients from the data as well as more complex features such as patches or gaps (Legendre, 1990; Borcard et al., 1992). The coefficient of determination $\left(\mathrm{R}^{2}\right)$ for this relationship was used as a measure of the component of the variation in richness that is explained by a combination of the non-environmental spatial component (component a) and the spatially structured environmental component (component $b$ ). The $\mathrm{R}^{2}$ values of the bivariate or multivariate relationships between species richness and environmental variables were used as a measure of the variation explained by a combination of the spatially structured environmental component (component $b$ ) and the non-spatial environmental component (component c). The variation in richness explained by components $a+b+c$ was determined from a model incorporating both the environmental and spatial variables. Tabulated partial regression model results were subject to sequential Bonferroni corrections. By subtraction the amount of variation accounted for by each of the components was estimated separately.

\section{RESULTS}

\section{Character at the faunal level}

\section{Biogeography}

The Indo-Pacific region has been divided into land snail faunal zones by a number of authors (e.g., Fischer, 1880-87; Cook, 1895; Solem, 1959). In his systematic and zoogeographic account of the land and freshwater molluscs of Vanuatu (then New Hebrides), Solem (1959) provided an illustrated synthesis of the earlier schemes, and concluded that there were three main faunal assemblages of land snails in the Indo-Pacific region, namely the Palaeo-Oriental, Pacific Island, and Southern Relict faunas. The Palaeo-Oriental Fauna, extending from Java to the Solomon Islands and including northeast Australia, was characterised by the Camaenidae, Cyclophoridae, Rathousiidae, and larger helicarionids. The Pacific Island Fauna, including the New Zealand territory of the Kermadec Islands, was recognised as endemic, but probably derived from the PalaeoOriental Fauna (Solem, 1959) (also see Pilsbry, 1900; Ladd, 1960; Cowie, 1996, the origins of the Pacific fauna). Southern Australia, New Zealand (exclusive of the Kermadecs), New Caledonia, South Africa and South America that comprise the Southern Relict Fauna were characterised by extensive radiation in the Rhytididae, Charopidae and Punctidae. The high specific and generic endemism shown by these taxa, and the presumptive endemic nature of the cyclophoracean family Liareidae (now tentatively assigned to Pupinidae - see below), has been the basis for recognising New Zealand (exclusive of the Kermadecs) as a distinct faunal zone (Solem, 1959; Climo, 1975).

The characteristic combination of families present in many parts of the Southern Relict zone (Rhytididae, Charopidae, Punctidae, Athoracophoridae, Bulimulidae, various cyclophoracean families), was thought by Solem (1959, p. 320-321) most easily explained as one 'basic' primitive fauna. Superimposed upon these basic elements are widely dispersed minor elements, comprising Achatinellidae, Succineidae, Assimineidae and Hydrocenidae. The 'basic' fauna has been modified by succeeding dispersal waves of land snails into areas such as northern Australia, but New Zealand has entirely escaped such dispersal events.

Some authors have argued for evolution of the New Zealand fauna in complete isolation since the Mesozoic (e.g. Climo, 1975 in respect to land snails). Molecular phylogenetic data for Athoracophoridae (G.M. Barker, unpubl.) support the view of evolution in the New Zealand region independent of sister taxa in the other sectors of the Southern Relict zone. However, in the absence of a more comprehensive molecular phylogeographic analysis of the land snail fauna it is in fact impossible to determine how much the evolution of the fauna has been impacted by chance dispersal. Studies in more mobile taxa, in both the flora and fauna, find support for at least some biotic interchange amongst sectors of the Southern Relict zone, and probably to the extent that eastern Australia and New Zealand functioned as a single biogeographic entity (e.g. Pole, 1993, 1994; McGlone et al., 2001; Winkworth et al., 1999, 2002; Brownsey, 2001). Nonetheless, several studies support strong biogeographic relationships between New Zealand and New Caledonia (e.g., Chambers et al., 2001; Ponder et al., 2003). The uninterrupted fossil record of certain plant taxa (Macphail, 1997), and the occurrence of ancient austral groups at lower elevations in modern New Zealand (Plants: Araucariaceae, Podocarpacaeae, Proteaceae, Winteraceae, Fagaceae - Suh et al., 1993; Manos, 1997; Hoot and Douglas, 1998; Stöckler et al., 2002. Animals: Emeidae, Dinornithidae, Apterygidae, Leiopelmatidae, Sphenodontidae, Rhytididae, Anostostomatidae, Peripatopsidae - Cooper and Millener, 1993; Gleeson, 1996; Cooper et al., 2001; and others) point to continuous lineages rather than long-distance dispersal (but see Pole, 1994; Briggs, 2003; and others for contrary views). The forestfloor invertebrate fauna often has a significant proportion of taxa showing Gondwanan affinities and is for this reason likely to be of great antiquity. Wardle et al. (1983) argued that the complexity of this fauna and its extreme sensitivity to anthropogenic modifications of the vegetation cover suggest that the fauna has 'co-evolved' over an 

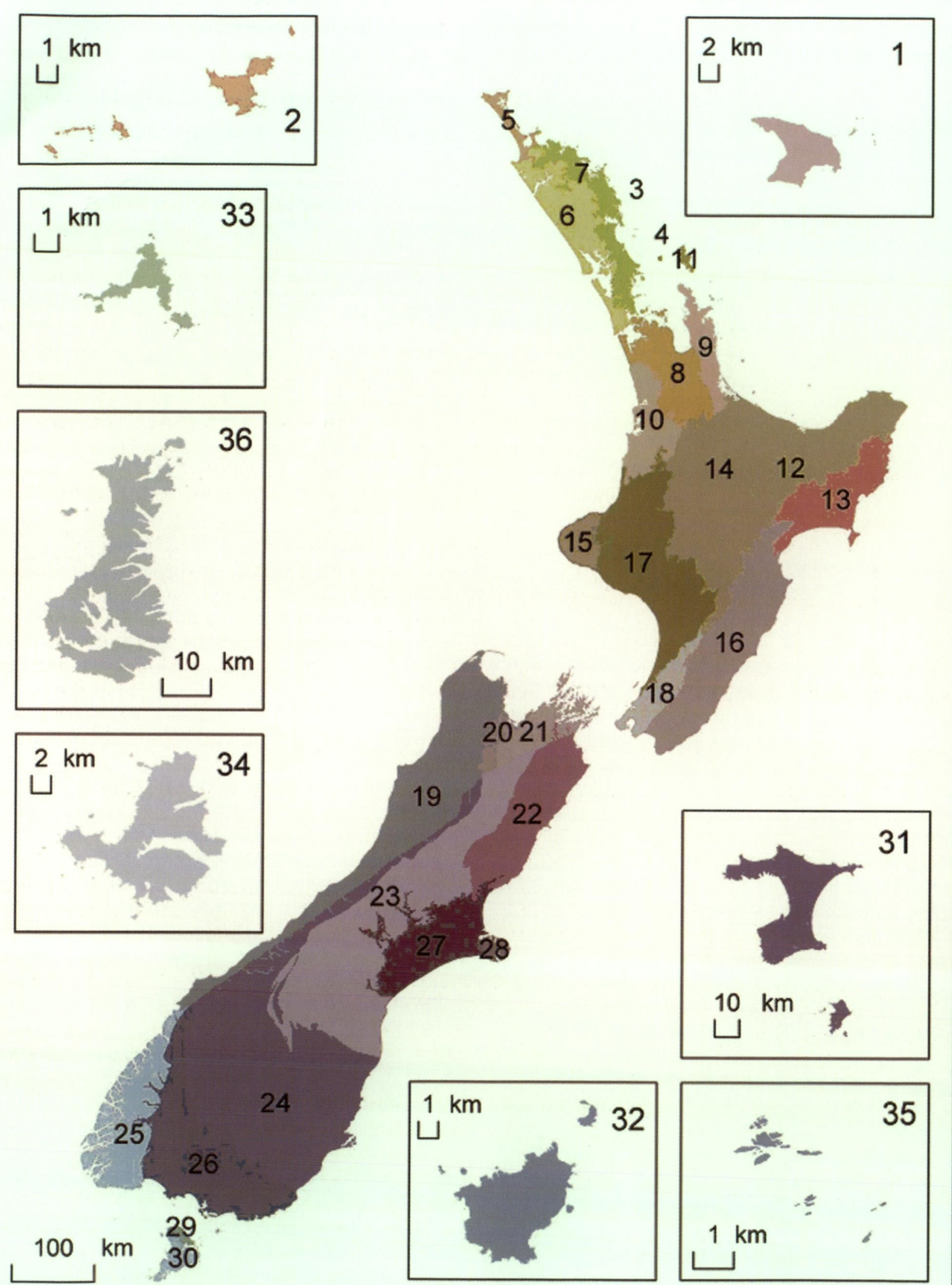

Figure 2 A bioregion classification of the New Zealand archipelago. Map showing geographic location of each of the 36 bioregions. 


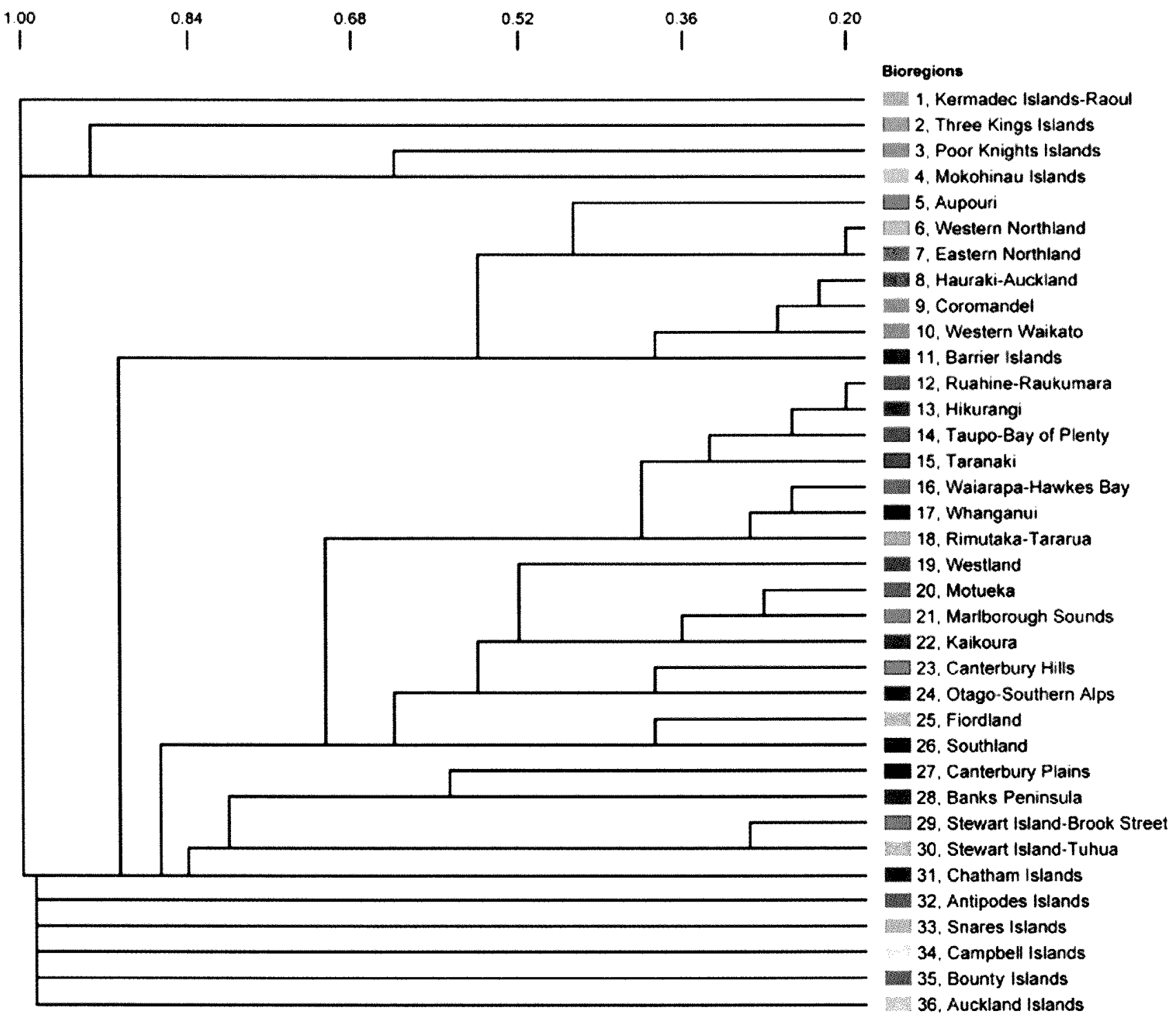

Figure 2B Dendrogram showing biotic relationships among the bioregions based on land snail assemblages.

extremely long time with the New Zealand forest. However, this generalization is not robust in all provenances or for all taxa (McQuillan, 1993). At least five species in the New Zealand land snail fauna (in Punctidae, Charopidae and Achatinellidae) also occur naturally outside the region, indicating relictual distributions and/or dispersal (see below).

Figure 2 illustrates a bioregion classification of New Zealand based on geophysical attributes of land units, adopted here as a spatial framework for considering intra-archipelago biodiversity patterns. The faunal relationships of these bioregions based on the land snail assemblages (exclusive of the Assimineidae, Ellobiidae, Hydrobiidae, and A thoracophoridae) are presented in Figure $2 \mathrm{~B}$. The bioregions of the northern North Island cluster separate from those distributed from the central North Island through to Stewart Island. The Chatham Islands bioregion exhibits the strongest affinities with Banks Peninsula and Stewart Island bioregions. The Kermadec Islands and subantarctic island bioregions were indicated to have highly distinctive assemblages. The Three Kings Islands bioregion formed a cluster with the Poor Knights and Mokohinau Islands bioregions, and distinct from other bioregions. No land snail data was available for the Kermadec Islands-Curtis bioregion.

Excluding Assimineidae, Ellobiidae, Hydrobiidae and Athoracophoridae, the total species richness for the bioregions ranged from 1 (Bounty Islands bioregion) to 347 for the Westland bioregion (Figure 3a). Westland had the highest number of bioregionendemic species (Figure 3B). When bioregionendemic species richness is expressed as a proportion of total bioregion-level species richness, the bioregions fall into four groups: Endemism Group I, >0.50 - Kermadec Islands-Raoul, Three Kings Islands, Snares Islands, Antipodes Islands, Bounty Islands; Endemism Group II, 0.25-0.50- 

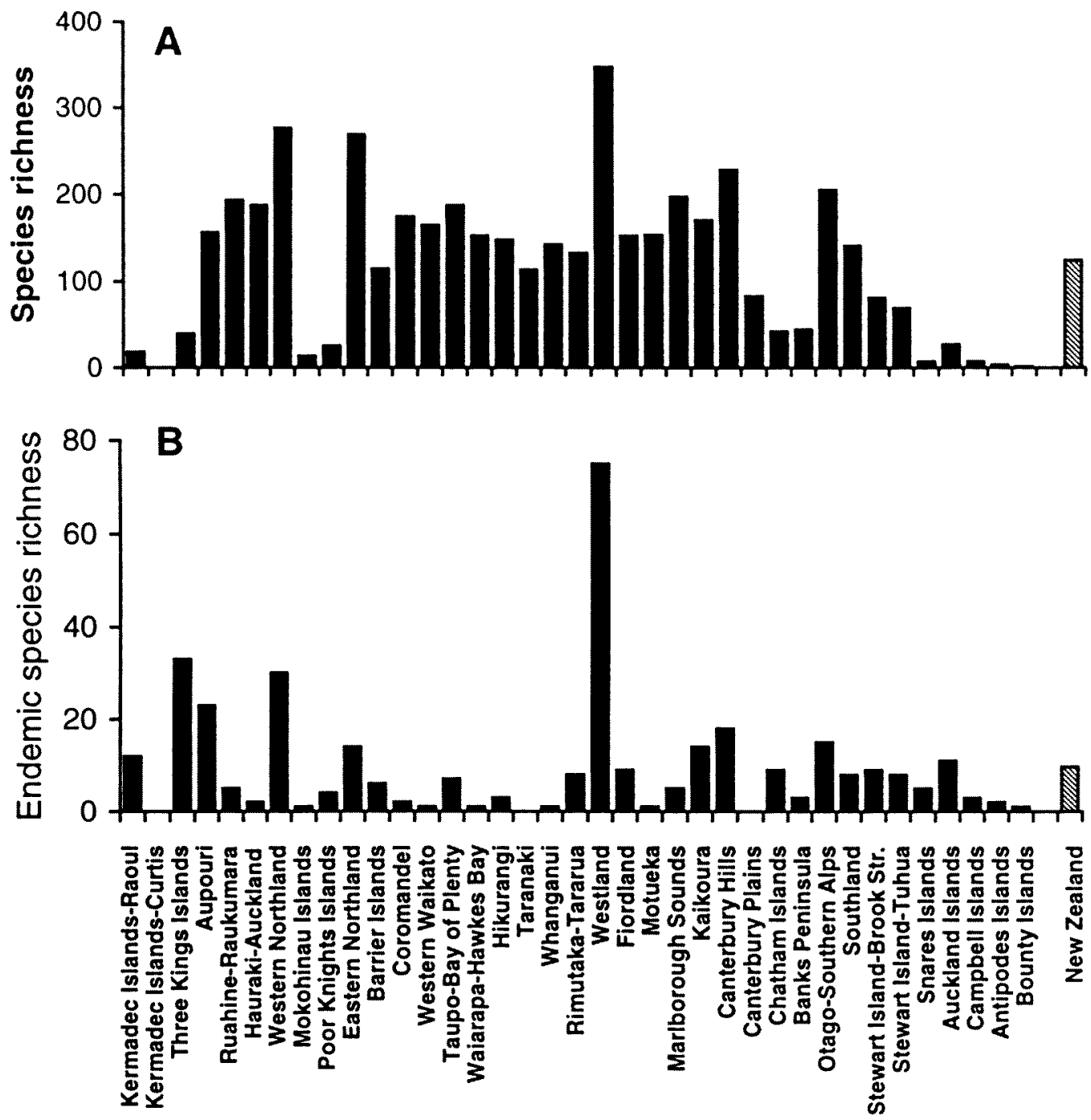

Figure 3 Variation among New Zealand bioregions in land snail species richness. (A) Total number of species recorded for each bioregion. (B) Total number of species endemic to each bioregion. Bioregions are ordered left to right in approximate sequence of increasing latitude south. The bar to the extreme right of each graph, labelled New Zealand, indicates the mean across all bioregions.

Auckland Islands, Campbell Islands; Endemism Group III, 0.05-0.25 - Aupouri, Eastern Northland, Western Northland, Poor Knights Islands, Mokohinau Islands, Barrier Islands, RimutakaTararua, Westland, Kaikoura, Canterbury Hills, Banks Peninsula, Otago-Southern Alps, Fiordland, Southland, Stewart Island-Brook Street, Stewart Island-Tuhua, Chatham Islands; Endemism Group IV,$<0.05$ - Hauraki-Auckland, Coromandel, Western Waikato, Taupo-Bay of Plenty, RuahineRaukumara, Hikurangi, Wairarapa-Hawkes Bay, Taranaki, Whanganui, Motueka, Marlborough Sounds, Canterbury Plains.

\section{Taxa groups}

The Kermadec Islands land snail fauna was last reviewed by Iredale $(1913,1915)$ and Oliver (1915). The composition of the New Zealand land snail fauna, exclusive of the Kermadecs, has been most recently reviewed by Climo (1975). In the last few decades there have been considerable advances in our understanding of the New Zealand fauna, with recognition of substantive undocumented radiation in Athoracophoridae, Pupinidae, Rhytididae, Punctidae and Charopidae. The essential points with respect to composition and likely origins of the fauna are summarised in Table 1 , and are elaborated upon in the following paragraphs.

The Neritopsina are poorly represented in New Zealand, with a single hydrocenid species, viz Georissa purchasi (Pfeiffer, 1862), distributed from the Three Kings to about $46^{\circ} \mathrm{S}$ in the South Island. This litter-dwelling detritivore is often numerically dominant in communities of the forest floor. The generic limits in hydrocenids have not yet been adequately studied so the placement of the New Zealand species in Georissa Blanford, 1864 should be treated as tentative. The low rate of speciation is not peculiar to the New Zealand region as a similar situation exists for hydroceneids in Australia and 
many Pacific Islands. However, hydroceneids have radiated extensively in some parts of their range, notably in Borneo (Thompson and Dance, 1983).

The Architaenioglossa are represented in New Zealand by the cyclophoracean genera Liarea Gray, 1852 and Cytora Kobelt and Moellendorff, 1897. The systematic affinities of these genera have not been fully resolved, reflecting in large part the poor understanding of the evolutionary history and unstable higher systematics of cyclophoraceans globally (Barker, 2001). Suter (1913) recognised affinities of Cytora with Cyclophoridaes. stricto, and Liarea with snails now classified not as cyclophoraceans but rather as omphalotropine Assimineidae. In Cyclophoridae s. lato, Thiele (1929-1935) assigned Cytora to Cyclophorinae, and Liarea to Pupininae. However, Morton (1952) and Climo $(1971,1973)$ have shown that anatomically these genera have more features in common than either has with extralimital taxa. Thus Climo (1975) and Powell (1979) treated these New Zealand genera as belonging to an endemic family. Nonetheless, Ponder and Warén (1988) and Spencer et al. (2005) have assigned Cytora and Liarea to Pupinidae. Both genera are absent from the Kermadecs. Liarea is distributed in the North Island, and most strongly diversified in the northern regions of the island. The genus comprises seven described and several undescribed species (F.J. Brook and G.M. Barker, unpubl.). Cytora occurs from the Three Kings Group to the Auckland Islands, with 19 valid described species, and at least 27 undescribed species (B.A. Marshall, D.J. Roscoe and G.M. Barker, in prep.). Cytora and Liarea are litter-dwelling detritivores that, with the exception of an occasional case of arborealism in some Cytora species, occur on the forest floor.

Among the 17 families of rissoidean caenogastropods recognized by Ponder (1988), only Pomatiopsidae, Truncatellidae, Assimineidae and Hydrobiidae are represented in terrestrial environments in various parts of the world (Barker, 2001). Of these, only Assimineidae and Hydrobiidae are represented in terrestrial situations in New Zealand.

Globally, the extant Assimineidae comprise two subfamilies. Assimineinae are widely distributed and are amphibious in marine and freshwater supralittoral situations, and more rarely in moist lowland terrestrial environments. Most have been referred to the genera Assiminea Fleming, 1828 and Paludinella Pfeiffer, 1841 but, as noted by Barker (2001), in the absence of comparative studies the systematic relationships and distributional limits of the genera cannot be defined. Assiminea vulgaris (Webster, 1905) is the sole described representative of Assimineinae in New Zealand, distributed in the supralittoral zone of marine shores from the Kermadec Group south to about $38^{\circ} \mathrm{S}$. Assiminea is a notable absentee from the Three Kings Islands group. Species of the primarily terrestrial subfamily Omphalotropinae occur in the Indo-West Pacific Islands - including Lord Howe Island - but are absent from Australia. The single described New Zealand representative, Suterilla neozelanica (Murdoch, 1899), occupies a similar supralittoral habitat to that of $A$. vulgaris, but its distribution extends from the Kermadecs to $41^{\circ} 25^{\prime} \mathrm{S}$ at the southern extremity of the North Island and ca $44^{\circ} \mathrm{S}$ in the Chatham Islands. However, present systematic studies (H. Fukuda, W.F. Ponder, B.A. Marshall, pers. comm.) indicate a species complex.

Hydrobiidae are among the most diverse and widespread of the non-marine caenogastropods. The global hydrobiid radiation encompasses some 140 genus-group taxa (Ponder, 1988; Kabat and Hershler, 1993) in brackish water and, more extensively, freshwater. The great diversity of modern hydrobiids is the result of their low vagility, with isolation in confinement to more-orless permanent water bodies leading to genetic differentiation and speciation at small spatial scales (e.g. Ponder et al., 1994, 1995). Some hydrobiids have become amphibious, but only Falniowskia Bernasconi, 1990 and Terrestribythinella Sitnikova, Starobogatov and Anistratenko, 1992 have become terrestrial. In the New Zealand region, hydrobiids are presently not known from the Kermadec Islands, but more than 60 species are now recognized from fresh- and brackish-water habitats extending from the Three Kings Islands group in the north to Auckland Islands in the South (Spencer et al., 2005; M. Haase, pers. comm.). Potamopyrgus antipodarum (Gray, 1843), the most common species of streams, lakes and ponds, is not infrequently found in moist litter on the forest floor, apparently associated with localised and somewhat seasonal seeps of freshwater from underground aquifers. In these situations, $P$. antipodarum is microsympatric with a community of obligate-terrestrial prosobranchs and stylommatophorans. There are occasional records from this type of habitat for the Stewart Island species Potamopyrgus cresswelli Climo, 1974.

Ellobiidae are pulmonate snails that are primarily inhabitants of marine littoral environments. However, a trend to fully terrestrial existence has evolved independently in several clades, albeit largely in lowland coastal situations (Martins, 1992 , 2001; Barker, 2001). The Ellobiidae exhibit an extensive radiation in the Indo-Pacific, with Ellobiinae, Pedipedinae, Melampinae and Pythiinae well represented. Nonetheless, only eight species are known to be indigenous to the New Zealand region, and only four species - Melampus albus Gassies, 1865 and Melampus luteus Quoy and Gaimard, 1832 (Melampinae) of the Kermadec Islands, Microtralia insularis (Powell, 1933) 
Table 1 The indigenous land snail families of the New Zealand region

\begin{tabular}{|c|c|c|c|c|}
\hline \multirow[t]{2}{*}{ Family } & \multicolumn{2}{|l|}{ Global diversity } & \multicolumn{2}{|c|}{ New Zealand region } \\
\hline & $\begin{array}{l}\text { Distribution, Habitat, Fossil record, } \\
\text { and Systematic relationships }\end{array}$ & $\begin{array}{l}\text { Approximate } \\
\text { species richness* }\end{array}$ & Geographic origin of fauna & Species richness \\
\hline \multicolumn{5}{|l|}{ Neritopsina } \\
\hline Hydrocenidae & $\begin{array}{l}\text { Warmer parts of the Old World, Africa, Madagascar, } \\
\text { Japan, India, China, Indonesia, New Guinea, Australia, } \\
\text { New Zealand to Polynesia and Hawaii. Terrestrial. } \\
\text { Closest extant relatives often assumed to be Helicinidae. } \\
\text { However, these families represent ancient, independent } \\
\text { invasions of the terrestrial environment. The hydrocenid } \\
\text { fossil record only extends to the Pleistocene, but much } \\
\text { older origin is probable. }\end{array}$ & 200 & ?Australasian Cenozoic dispersal. & 1 \\
\hline \multicolumn{5}{|c|}{ Architaenioglossa, Cyclophoracea } \\
\hline Pupinidae & $\begin{array}{l}\text { SE Asia through Micronesia and Melanesia to New } \\
\text { Guinea, Australia and New Zealand. Terrestrial. Closest } \\
\text { cyclophoracean relatives presently not known. Earliest } \\
\text { fossils attributed to family occur in European. } \\
\text { Cretaceous deposits. }\end{array}$ & 350 & $\begin{array}{l}\text { Australasian Cretaceous vicariance } \\
\text { In situ cladogenesis and speciation. }\end{array}$ & 56. \\
\hline \multicolumn{5}{|c|}{ Sorbeoconcha, Rissooidea } \\
\hline Assimineidae & $\begin{array}{l}\text { Widely distributed globally, principally in temperate } \\
\text { and tropical lowland regions. Amphibious in marine, } \\
\text { brackish and freshwater littoral-supralittoral zones. } \\
\text { Closest extant relatives probably the aquatic } \\
\text { Pomatiopsidae and the supralittoral to terrestrial } \\
\text { Truncatellidae. Earliest fossils attributed to } \\
\text { Assimineidae occur in European and North American } \\
\text { Miocene deposits, but primarily radiation probably } \\
\text { occurred by the Upper Jurassic. }\end{array}$ & 300 & $\begin{array}{l}\text { Australasian or Melanesian } \\
\text { Cenozoic dispersal. }\end{array}$ & 3 \\
\hline Hydrobiidae & $\begin{array}{l}\text { Worldwide except in the polar regions. Primarily aquatic. } \\
\text { Closest relatives are the aquatic Bithynidae, } \\
\text { Lithoglyphidae and Moitessieriidae. Hydrobiids have a } \\
\text { poor fossil record, but many are known from the } \\
\text { European early Tertiary. }\end{array}$ & $\begin{array}{l}1200 \text { aquatic (ca } 5 \\
\text { semi-terrestrial to } \\
\text { terrestrial) }\end{array}$ & $\begin{array}{l}\text { Gondwanan origins. Australasian } \\
\text { Cretaceous vicariance. In situ } \\
\text { cladogenesis and speciation }\end{array}$ & $\begin{array}{c}62 \text { aquatic }(2 \\
\text { semi terrestrial) }\end{array}$ \\
\hline
\end{tabular}


Pulmonata, Stylommatophora

Achatinellidae Islands of the Pacific Ocean and along the western margin of the Pacific. Terrestrial. Member of the

Pyramidulidae and Vertiginidae.

Athoracophoridae Western Pacific, from New Guinea, Melanesia, Australia and New Zealand. Terrestrial. Closely related to Succineidae. No fossil record.

Bulimulidaes.l. Neotropics, Melanesia, Australia and New Zealand. Terrestrial. Traditionally assumed to be most related to Urocoptidae. Earliest bulimulid fossils from the Eocene of South America.

Charopidae Presently, Australia, New Zealand, Philippines and Indonesia to New Caledonia and Polynesia, Micronesia and Fiji, South Africa, Madagascar, and Seychelles, Americas, St Helena. Terrestrial. Sister taxon to Punctidae. Oldest fossils of Miocene deposits of the Pacific Eniwetok Atoll.

Euconulidae Worldwide except polar regions. Terrestrial. Closely related to Helicarionidae, Ariophantidae and

Trochomorphidae.

Punctidae Worldwide except polar regions - principally Africa, Indian Ocean, Holarctic and Australasia. Terrestrial. Sister taxon to Charopidae. Known from the European Oligocene.

Rhytididae Indonesia to Melanesia (including Fiji and Tonga), Australia, South Africa, Madagascar and Seychelles. Terrestrial. Closely related to Acavidae. Oldest fossils known from the Pliocene of New Zealand.

Succineidae Worldwide except polar regions. Terrestrial, often with amphibious tendencies. Sister taxon to Athoracophoridae.

Earliest known succineid fossils are known from Palaeocene of Europe and the Tertiary of Africa, Europe and North America.

Placostylinae relictual in eastern Gondwanan provinces.

Melanesian Cenozoic dispersal.

Mixed Australasian Cretaceous vicariance and Pacific Cenozoic dispersal. In situ cladogenesis and speciation.

Gondwanan. Australasian Cretaceous vicariance. In situ cladogenesis and speciation.

?Australasian Cenozoic dispersal.

Vertiginidae s. lat. Worldwide except polar regions. Terrestrial. Member of the orthurethran clade, probably related to Achatinellidae and Pyramidulidae. 
(Pedipedinae) of northern North Island, and Leuconopsis obsoleta (Hutton, 1878) (Pedipedinae) distributed widely in the region - exhibit some terrestriality in extending from their primarily upper littoral habitat into the supra-littoral zone.

The great majority of land snails in the New Zealand region comprise Stylommatophora, in the families Achatinellidae, Athoracophoridae, Bulimulidae, Charopidae, Euconulidae, Punctidae, Rhytididae, Succineidae and Vertiginidae (sensu lato).

Recent Achatinellidae are endemic to islands of the Pacific Ocean and along the western margin of the Pacific. For the most part the family comprises narrow-range species. Only a few small arboreal species are widely distributed (Cooke and Kondo, 1960; Kondo, 1962), in part possibly due to prehistoric transportation by man. The occurrence of achatinellids in islands of the Indian Ocean is assumed to be the result of recent human introductions. Thus the present Pacific distribution seems to be relictual of an earlier Pacific Basin radiation. Palaeozoic Anthracopupa Whitfield, 1881 in North America and Europe, and Cretaceous Protornatellina White, 1883 of North America have been attributed to Achatellinidae on conchological grounds (Solem and Yochelson, 1979). However, Tillier (1989) rightly questioned the validity of these assignments. The New Zealand Achatinellidae comprise only five species: Tubuaia raoulensis (Pilsbry and Cooke, 1915) and Tornatellinops iredalei (Pilsbry and Cooke, 1915) are apparently confined to the Kermadec Islands, Tornatellides subperforatus (Suter, 1909) occurs in the Kermadecs and extends to the northern regions of the North Island, Tornatellinops novoseelandica (Pfeiffer, 1853) occurs in the Kermadec and Three Kings island groups and extends south to latitude $41^{\circ} \mathrm{S}$ in the North Island and $44^{\circ} \mathrm{S}$ in the Chatham Islands, and Elasmias apertum (Pease, 1864) is widely distributed in the Pacific and occurs in the Kermadec Islands. These five achatinellids are partially arboreal in coastal forest and shrubland environments.

The vertiginid genus Pronesopupa Iredale, 1913 is widely distributed in the islands of the Pacific. Pronesopupa senex Iredale, 1913 of the Kermadec Islands, the type species, is the sole representative of the family in the New Zealand region. Stanisic (1998) and others place the nesopupine snails in the family Pupillidae, but affinity with vertiginines recognised by Schileyko (1998) is supported by molecular phylogenetic analyses (C.M. Wade and P. Mordan, pers. comm.).

The Euconulidae are represented in New Zealand by three Kermadec Islands species, namely Kieconcha kermadeci (Pfeiffer, 1856), Fanulum expositum (Mousson, 1873) and Kermarion kermadecensis (E.A. Smith, 1873), in monotypic and, therefore, Kermadec Islands-endemic genera. The family units within the helicarionoid snails have been variously treated by different authors. I have followed Schileyko (2002a, b) by including these and other microcystines with the kaliellines and euconulines in the Euconulidae. The speciose Microcystinae are distributed from SE Asia and Indonesia to the islands of the Pacific. As indicated in Table 1, the Kermadec Islands taxa probably arose from ancestral stock established as part of the microcystine dispersal from Asia during the Cenozoic. As is commmon for many euconulids, the Kermadec Islands species rest mostly on the ground, but are active primarily in arboreal sites.

In the family Rhytididae, 41 species-level taxa described from New Zealand are recognised here as valid. In addition, there are at least 22 species awaiting formal description (see Efford, 1998; Walker, 2003: Spencer et al., 2005). Members of Delouagapia Powell, 1952, Amborhytida Climo, 1974 and Rhytidarex Powell, 1948 are confined to the Three Kings Islands and northern North Island, Paryphanta Albers, 1850 to northern North Island, Delos Hutton, 1904 to the Three Kings to northern South Island, Schizoglossa Hedley, 1892 to North Island and adjacent smaller islands, Wainuia Powell, 1930 to southern North Island and northern South Island, Rhytida von Martens, 1860 to North, South and Stewart Islands and some adjacent smaller islands, and Powelliphanta O'Connor, 1945 to southern North Island and extensively in the South Island. Thus rhytidids are notably absent from the Kermadec Islands, Chatham Islands and the Subantarctic Islands. All the above taxa are endemic to New Zealand, although Roscoe (1989) points to several species presently assigned to Delos that may be congeneric with the eastern Australian Prolesophanta Iredale, 1933. These carnivorous snails (see Barker and Efford, 2004) occur in shrubland, forest and subalpine grasslands.

The family Bulimulidae is represented in New Zealand by three species of the placostyline genus Placostylus Beck, $1837 \mathrm{~s}$. lat. The occurrence of these species represents the southern extension of an essentially Melanesian distribution encompassing Lord Howe Island, New Caledonia, Fiji, Vanuatu, Santa Cruz, and the Solomon Islands. As indicated in Table 1, the presence of placostylines in New Zealand is traditionally attributed to Cenozoic dispersal. Within the constraints of limited taxon sampling, a molecular phylogenetic analysis led Ponder et al. (2003) to suggest that the northern North Island sister species Placostylus ambagious Suter, 1906 and $P$. hongii (Lesson, 1830) - with close affinities to the Lord Howe Island taxon $P$. bivaricosus (Gaskoin, 1855) - represent an independent colonisation event from that of the Three Kings Islands P. bollonsii Suter, 1908. However, the Bulimulidae are generally regarded as Gondwanan, despite their absence from Africa 
and India (Solem, 1998), so it is possible that presence of Placostylus in New Zealand is relictual and not primarily the result of dispersal. The contemporary distributional patterns exhibited by the three species in coastal forests and shrublands of northern New Zealand are correlated with Pliocene land distribution (Climo, 1973, 1975), albeit modified by human transportation (Hayward and Brook, 1981; Brook and McArdle, 1999).

The Succineoidea comprise the Succineidae and Athoracophoridae, which Barker (2001) postulated to represent a monophyletic clade with sister relationships to the remaining Stylommatophora. The Succineidae are distributed throughout the world, and despite extensive cladogenesis and speciation in the islands of the Pacific, are represented in New Zealand by a single extant, endemic species. Succinea archeyi Powell, 1933 occurs in coastal dune systems of northem North Island. Athoracophoridae are confined to the SW Pacific, extending from New Guinea through parts of eastern Australia and Melanesia to New Zealand and the Subantarctic Islands. The family has undergone a modest, monophyletic radiation in New Zealand, with about 47 species variously distributed from the Three Kings, throughout the North, South and Stewart Islands (including most smaller adjacent islands), to the Subantarctic and Chatham Islands. Athoracophorids occupy all terrestrial environments from marine supralittoral to alpine.

Collections in NMNZ and AIM presently house at least 450 species-level taxa of the family Charopidae from New Zealand. Only 210 of these species have been formally described. Discocharopa aperta (Moellendorff, 1888) is represented in the New Zealand region only in the Kermadec Islands, and its range extends widely in the Pacific (Solem, 1983). All other New Zealand charopid species are endemic. The majority of genera formally attributed to New Zealand charopids are likewise endemic. However, generic names established for extralimital species have been formally (e.g., Egestula Iredale, 1915; Rotadiscus Pilsbry, 1926; Geminoropa Kershaw, 1955) and informally (e.g., Elsothera Iredale, 1933; Sinployea Solem, 1982) (F.M. Climo, unpublished manuscripts in NMNZ) applied to New Zealand species, indicating faunal links to Australia, the Pacific and even to the Americas. Climo (1989) suggested that Egestula belongs in the Helicodiscidae - an assignment accepted by Spencer et al. (2005). However, Schileyko (2001) correctly pointed out that the reproductive anatomy of Egestula is charopid, not helicodiscid. In excess of 50 generic-level taxa are informally recognised among the New Zealand charopids, reflecting the high level of cladogenesis that characterises the fauna.

The hyperdiversity of New Zealand charopids is closely matched by Punctidae. Ninety punctid species have been described and currently recognised as valid, distinct entities within the New Zealand region. Collections at NMNZ and AIM presently house at least 286 additional undescribed New Zealand species-level taxa. Only three indigenous species are presently known to have ranges extending beyond New Zealand. Pasmaditta jungermanniae (Petterd, 1879) and Punctidae sp. 81 (NMNZ M.68844)' occur widely in New Zealand and in Tasmania, Australia. Paralaoma servilis (Shuttleworth, 1852) (Helix caputspinulae Reeve, 1852 and Paralaoma raoulensis Iredale, 1913 applied to New Zealand material are synonyms) occurs widely in New Zealand, and is known from many other parts of the world for which it is adventive. Additionally, Phrixgnathus hamiltoni (Suter, 1896) occurs in both the New Zealand subantarctic islands and the Australian Macquarie Island. Eight generic group taxa are formally recognised in the New Zealand Punctidae, including Phrixgnathus Hutton, 1883, Paralaoma Iredale, 1913 and Pasmaditta Kershaw and Smith, 1986, which have ranges extending beyond the region. However, this usage underplays the considerable cladogenesis that has occurred in New Zealand and informally as many as 70 generic group names have been applied to the region's Punctidae (F.M. Climo, unpublished manuscripts in NMNZ). Informally, genera established for extralimital species have been recognised as applicable to New Zealand species, including Insullaoma Iredale, 1937, Magilaoma Iredale, 1937, Iotula Iredale, 1941 (all Australia), Punctum Morse, 1864 (Holarctic, southern Africa), and Toltecia Pilsbry, 1926 (Americas) (F.M. Climo, unpublished manuscripts in NMNZ). For both Charopidae and Punctidae, the marked cladogenesis and extraordinary speciation indicate a level of local diversification greatly exceeding that recognised in the malacological literature (e.g., Schileyko, 2001, 2002a) and point to New Zealand as the global centre of diversity for these families. While primarily shrubland and forest-dwelling, charopids and punctids occupy all terrestrial environments in New Zealand from the marine supralittoral to the high alpine.

As summarised above, eleven families are now represented in New Zealand terrestrial environments. This modern fauna of New Zealand reflects a limited range of taxonomic antecedents through differential survivals of vicariant Gondwanan elements, and possibly supplemented by the establishment of chance colonists. This basic fauna has undergone substantial endemic cladogenesis and speciation. Given that at least some families are also well represented in other Gondwanan remnants, the New Zealand fauna may be regarded as naturally rich, secondarily depleted, then again rich. Among terrestrial families well 
represented in the Australasian-Pacific region, notable absences from the New Zealand fauna include Helicinidae (Neritopsina), Cyclophoridae, Cochlostomatidae (Architaenioglossa), Truncatellidae (Sorbeoconcha), Rathouisiidae, Vaginulidae (Rathouisioidea), Clausiliidae, Trochomorphidae, Cystopeltidae, Corillidae, Camaenidae, Bradybaenidae and Endodontidae (Stylommatophora). With the absence of most of the 80 or more families known globally, the fauna might be regarded as disharmonic. However, this low rate of representation at the family level is not unusual for regional faunas, either continental or archipelagic, and simply reflects the largely subglobal distributions of families.

The above analysis shows that the fauna has a skewed distribution of richness, with several families (notably Charopidae and Punctidae) comprising large numbers of species and thus contributing a disproportionately large amount to total diversity. Aggregated across all represented families, the presently recognized richness in obligate terrestrial species is 998 . All but five species $(99.5 \%)$ are endemic to the New Zealand region. Rarefraction analyses (not shown) yield estimates for the fauna of between 1,350 and 1,400 species, suggesting that a substantive number of endemic, species-level taxa await recognition. To this total should be added the nine species with semi-terrestrial, supralittoral tendencies.

\section{Species-area relationships}

The records available in the present study indicate that land snail species are presently unknown from 2,211 of the 9,573 islands in the New Zealand region. For a further 5,375 islands the collection data is sparse, and generally comprise one or two species represented in collections by a small number of specimens. For only 87 islands has the collection effort been sufficient to provide robust estimates of species richness. For this latter data set, the species richness-island area relationship (Figure 4a) took the form

$$
S_{i}=12.368 A_{i}^{0.210}, \mathrm{R}^{2}=0.49 \text {, d.f. }=86, \mathrm{P}<0.001
$$

where $S_{i}$ is species richness at the island scale, and $A_{i}$ is island area in units of $\mathrm{km}^{2}$. Regression analyses indicate that the level of explanation can be improved by inclusion of annual mean temperature (AMT) as a predictor in the model, thus

$$
\begin{gathered}
S_{i}=2.936 A_{i}^{0.236} 1.1225^{A M T}, \mathrm{R}^{2}=0.57, \text { d.f. }=86, \mathrm{P}< \\
0.001
\end{gathered}
$$

The number of environment types was strongly correlated with area $(r=0.80)$ and thus was excluded from the above models. However, environmental diversity can have causal links to richness and thus offers an alternate framework for
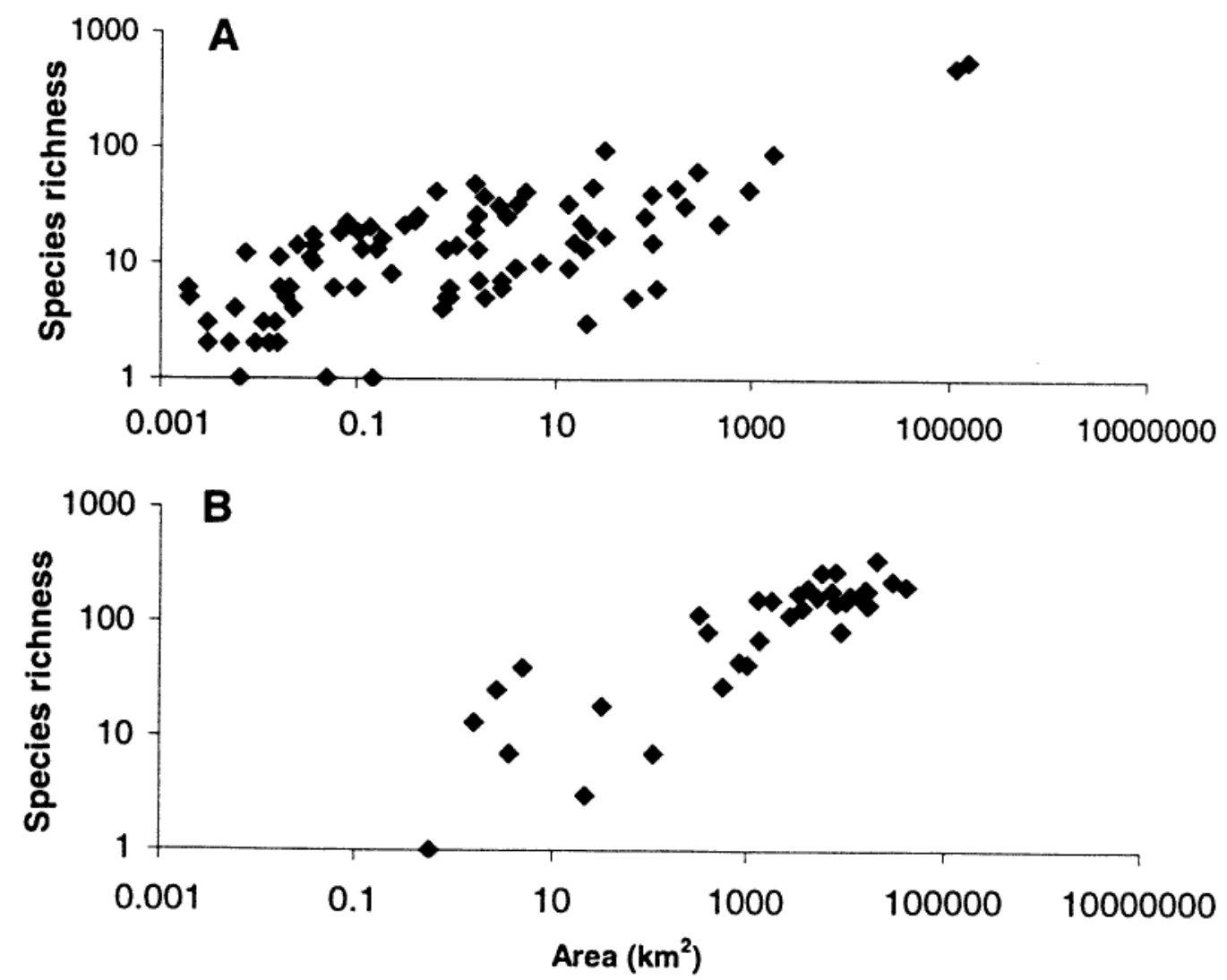

Figure 4 Species richness-area relationships for New Zealand land snails. (A) Land snail assemblages on a sample of 87 islands for which sampling effort has been adequate to determine species richness. (B) Land snail assemblages within bioregions $(n=36)$. 
prediction. Substituting island area by numbers of environments gave

$$
\begin{aligned}
& S_{i}=7.388 E_{i}^{0.596}, \mathrm{R}^{2}=0.41 \text {, d.f. }=86, \mathrm{P}<0.001 \\
& \text { and } \\
& S_{i}=3.505 E_{i}^{0.608} 1.061^{A M T}, \mathrm{R}^{2}=0.43 \text {, d.f. }=86, \mathrm{P}< \\
& 0.001,
\end{aligned}
$$

where $E_{\mathrm{i}}$ is the number of environment types within an island.

The species richness-bioregion area relationship (Figure $4 \mathrm{~b}$ ) took the form

$$
S_{b}=5.089 A_{b}^{0.381}, \mathrm{R}^{2}=0.75, \text { d.f. }=35, \mathrm{P}<0.001
$$

where $S_{b}$ is species richness at the bioregion scale, and $A_{b}$ is bioregion area in $\mathrm{km}^{2}$. Regression analyses indicated that the level of explanation could be improved by inclusion of annual mean temperature $(A M T)$ as a predictor in the model, thus

$$
\begin{gathered}
S_{b}=0.730 A_{b}^{0.423} 1.160^{\text {AMT }}, \mathrm{R}^{2}=0.85 \text {, d.f. }=35, \mathrm{P}< \\
0.001
\end{gathered}
$$

The number of environment types was strongly correlated with bioregion area $(r=0.93)$ and thus was excluded from the above models. Substituting numbers of environments for area, regression analyses yielded the following models and

$$
\begin{gathered}
S_{b}=6.647 E_{b}{ }^{0.759}, \mathrm{R}^{2}=0.79, \text { d.f. }=35, \mathrm{P}<0.001 \\
S_{b}=2.199 E_{b}{ }^{0.787} 1.095{ }^{A M T}, \mathrm{R}^{2}=0.83, \text { d.f. }=35, \mathrm{P}< \\
0.001
\end{gathered}
$$

where $E_{b}$ is the number of environment types within a bioregion.

The value of the slope $(z)$ of the regression of loglog species-area relationships has been subject to much debate, but its biological significance is still not fully understood (see Cowie, 1995; Rosenzweig, 1995, for recent discussion). It seems that $z$ values increase with increasing importance of in situ evolution of species over that of colonisation (Williamson, 1988; Cowie, 1995; Rosenzweig, 1995).
In the present study, the $z$ values in the log-log species-island area relationships are rather modest and thus indicate dominance of dispersal at the archipelago level over persistence of endemism at the individual island level. The higher $z$ values in the species-bioregion area and speciesenvironment area relationships may be interpreted as indicating a greater faunal turnover among the environmental and biogeographic provinces.

\section{Ecological diversity and functional gaps}

A fundamental ecological question is whether the New Zealand land snail fauna is at equilibrium, in terms of biological fitness and distributional ranges, in respect to the current range of environments. Regional faunas, such as that of New Zealand, are unlikely to contain the full complement of the ecological potential available globally, because the early regionalisation due to continental fragmentation and dispersal patterns limit the spectra of phylogenetic diversity. Moreover, island systems characteristically lack entire groups of organisms due to stochastic processes (Simberloff, 1995). While undoubtedly past climates and associated ecosystem factors have acted as selection agents on lineage persistence and speciation, the current fauna may have only limited fitness in contemporary environments due to the conservative nature of ecological niches and the differential pace of evolution relative to environmental change.

\begin{tabular}{|c|c|c|c|c|c|c|c|c|c|c|}
\hline & \multicolumn{3}{|c|}{ Geographic Range (km) ${ }^{1}$} & \multicolumn{3}{|c|}{ Environmental Niche Breadth ${ }^{2}$} & \multicolumn{3}{|c|}{ Climatic Niche Breadth ${ }^{2}$} \\
\hline & & Mean & Range & $\mathrm{SE}$ & Mean & Range & $\mathrm{SE}$ & Mean & Range & SE \\
\hline Achatinellidae & 5 & 634 & (5 to 1579 ) & 385 & 0.39 & $(0.29$ to 0.59$)$ & 0.06 & 0.12 & $(0.05$ to 0.36$)$ & 0.06 \\
\hline Athoracophoric & lae 47 & 248 & $(<1$ to 2068$)$ & 56 & 0.32 & $(<0.01$ to 0.63$)$ & 0.05 & 0.11 & $(<0.01$ to 0.87$)$ & 0.04 \\
\hline Bulimulidae & 3 & 372 & $(14$ to 780$)$ & 223 & 0.20 & $(<0.01$ to 0.30$)$ & 0.10 & 0.03 & $(0.01$ to 0.05$)$ & 0.01 \\
\hline Charopidae & 450 & 430 & $(<1$ to 2766$)$ & 25 & 0.25 & $(<0.01$ to 0.69$)$ & 0.01 & 0.09 & $(<0.01$ to 0.97$)$ & $<0.0$ \\
\hline Euconulidae & 3 & 5 & $(<1$ to 8$)$ & $<1$ & 0.12 & $(<0.01$ to 0.13$)$ & 0.01 & 0.01 & $(<0.01$ to 0.02$)$ & $<0.01$ \\
\hline Hydrocenidae & 1 & 1,854 & & & 0.65 & & & 0.36 & & \\
\hline Punctidae & 361 & 409 & $(<1$ to 2368$)$ & 29 & 0.24 & $(<0.01$ to 0.66$)$ & 0.01 & 0.08 & $(<0.01$ to 0.38$)$ & $<0.01$ \\
\hline Pupinidae & 56 & 517 & (<1 to 2018$)$ & 86 & 0.31 & $(<0.01$ to 0.64$)$ & 0.03 & 0.09 & $(<0.01$ to 0.34$)$ & 0.02 \\
\hline Rhytididae & 67 & 243 & $(<1$ to 1422$)$ & 37 & 0.24 & $(0$ to 0.63$)$ & 0.03 & 0.06 & $(<0.01$ to 0.29$)$ & 0.01 \\
\hline Succineidae & 1 & 964 & & & 0.09 & & & 0.06 & & \\
\hline Vertiginidae & 1 & 5 & & & 0.01 & & & 0.01 & & \\
\hline \multicolumn{2}{|c|}{ Mean (at species level) } & 407 & $(<1$ to 2766$)$ & 47 & 0.25 & $(0$ to 0.68$)$ & 0.01 & 0.08 & $(<0.01$ to 0.97$)$ & $<0.01$ \\
\hline
\end{tabular}

The geographic range over which species occur within the New Zealand archipelago varied from a few meters for species known only from single localities (35 species) to $>2,700 \mathrm{~km}$ for Phenachoropa pseudanguicula (Iredale, 1913) and Huonodon hectori (Suter, 1890). The average geographic range

Table 2 Means of geographic range size and breadths of environmental and climatic niches estimated for land snail species in families represented in New Zealand terrestrial environments.

1. A geographic range size of $2,680 \mathrm{~km}$ indicates a distribution throughout the latitudinal extent of the New Zealand archipelago.

2. Environmental niche breadth based on 5 climate and 5 soil parameters. Climate niche based on 4 climate parameters. See Materials and Methods for full explanation. A niche breadth value of 1.0 indicates occupancy of the full range of environments available within the New Zealand archipelago. 
occupied by a species within New Zealand was 407 $\mathrm{km}( \pm 47 \mathrm{SE}$ ) (Table 2), which equates to about 0.15 of the total latitudinal extent of the New Zealand archipelago. In environmental space, on average, species occupied about $0.246( \pm 0.007 \mathrm{SE})$ of the total available niche (Table 2). Only 81 species or about $8 \%$ of the fauna (including P. pseudanguicula and $H$. hectori), occupied more than 0.60 of the available environmental niche. When only climate is considered, the average niche breadth was a mere $0.082( \pm 0.003 \mathrm{SE})$, and only two species (Cavellia brouni (Suter, 1891) and Charopa bianca (Hutton, 1883)) occupied more than 0.60 of that available.
These analyses point to considerable variation in the degree of niche specialisation among New Zealand land snails, and suggest greater specialisation within the spectra of available climates than in relation to soils. From the fact that many species have a rather wide geographic range and broad environmental niche, it may be concluded that small punctids and charopids evidently have good powers of dispersal, and are catholic in environmental requirements. Unfortunately, in the absence of phylogenies, it is presently not possible to relate geographic and environmental range to species ages.
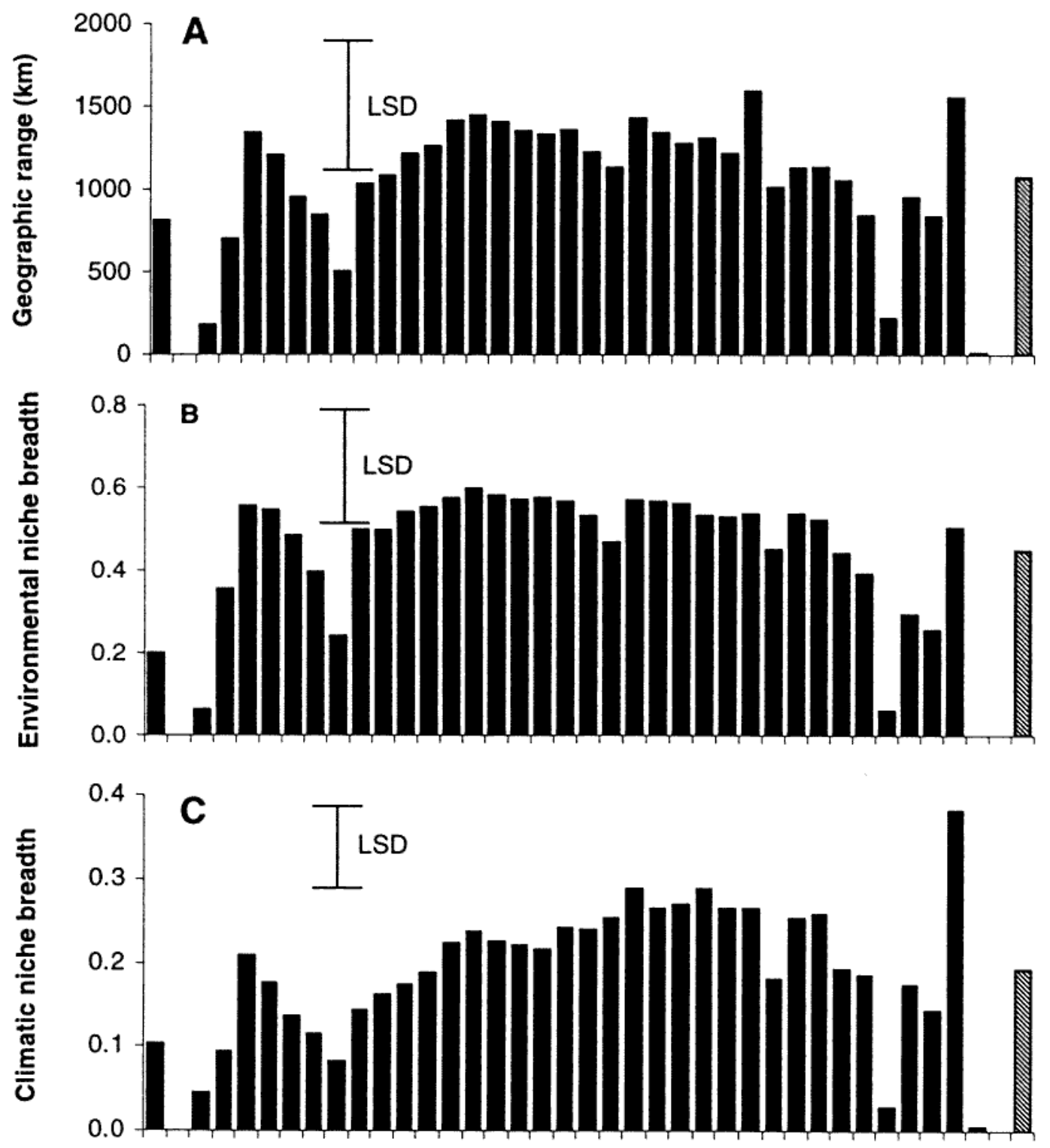

Figure 5 Variation among New Zealand bioregions in geographic range size and niche breadth of species in the land snail assemblage. (A) Mean geographic range. (B) Mean breadth of the environmental niche. (C) Mean breadth of the climatic niche. Note that range and niche are only calculated for the New Zealand region and do not include any extralimital range species may have. Excluded are the Ellobiidae (marine littoral to supralittoral), Hydrobiidae (aquatic, with 2 species occasionally semi-terrestrial), and Assimineidae (marine littoral to supralittoral). Bioregions are ordered left to right in approximate sequence of increasing latitude south, as in Figure 4 . The bar to the extreme right of each graph, indicates the mean across all bioregions. LSD is the least significant difference between mean values. 
Sampled at the scale of bioregions, the mean geographic range of species in assemblages was $1,074 \mathrm{~km}( \pm 94 \mathrm{SE})$, while climate and environmental niche breadth averaged $0.19( \pm 0.007$ $\mathrm{SE})$ and $0.45( \pm 0.14 \mathrm{SE})$, respectively. Ignoring the special case of the Bounty Islands where only a single species is known, all bioregion assemblages exhibited considerable inter-specific variation in range size and niche breadth (Figure 5), reflecting the varying mixes of bioregion-endemic species, non-endemic but niche specialist species, and species with broad ranges and niches. Nonetheless, statistically significant differences between bioregions were indicated, with lower mean geographic range sizes and niche breadths for assemblages of the Kermadec Islands-Raoul, Three Kings Islands, Aupouri and Poor Knights Islands Bioregions - which represent bioregions of small extent and with largely locally-endemic faunas. That island area per se is not universally dominant in effect is evident in the broad geographic ranges and environmental niches of the assemblages of the Mokohinau Islands, Chatham Islands, and Campbell Islands.

Consistent with the predominantly forested landscape, the New Zealand land snails are primarily obligate inhabitants of closed-canopy vegetation communities. The 3-dimensional complexity of forest, with its several tiers or storeys of plants and a wide variety of organic detritus, provides a diversity of microhabitats for land snails. Extensive collecting experience in New Zealand points to the fact that, in general, more species of land snails are found in forest environments than in less complex and more open systems such as grasslands and early successional shrublands. The sheer volume of the forest above-ground biomass can be viewed as providing great capacity for buffering the detritus and associated animals from the vagaries of the climate. Despite their great dependency on moisture, land snails are common inhabitants of xeric habitats in many regions of the world. Snails persist in these dry environments by adopting several moisture conserving strategies commonly they seal the shell aperture with robust, calcified epiphragms, and either attached to the substrate or buried in the soil, they aestivate for all but the brief periods when moisture becomes available through rainfall or heavy dews. These desiccation-tolerant snails generally possess robust shells. Such snails are absent from New Zealand. Most New Zealand land snails appear to be incapable of surviving extended dry periods in aestivation. However, species with small, tightly coiled shells, small apertures, and some limited capability to form thin, non-calcified epiphragms, do occur in dry New Zealand environments. $T$. subperforatus, $T$. novoseelandica, E. apertum, T. iredalei (Achatinellidae) and P. senex (Vertiginidae sensu lato) are the most striking examples of small, desiccation-tolerant species. These occur in dry litter and are to varying degrees arboreal, occurring cryptically on the undersides of the foliage of understorey angiosperms and on the standing twigs of dead shrubs. A number of small punctids also exhibit some tolerance of dry conditions and often occur in abundance in drought-prone coastal forest and shrublands, and semi-xeric shrublands of the eastern districts of the North and South Islands. Typical of this group are $P$. servilis and 'Punctidae sp. 100 (NMNZ M.84972)'.

The New Zealand arboreal fauna is generally rather depauparate, probably reflecting the strong gradient of declining humidity with height above the forest floor and the large diurnal variation in moisture in the canopy in many areas of the country. Nonetheless, there is a suite of charopid and punctid species that are not uncommonly found in the lower arboreal tiers of the forest under high moisture conditions. These include Phrixgnathus celia Hutton, 1883, Ph. cognata (Suter, 1909), Ph. erigone (Gray, 1850), Ph. glabriusculus (Pfeiffer, 1853), Ph. moellendorffi (Suter, 1896), 'Punctidae sp. 40 (NMNZ M.88216)', 'Punctidae sp. 56 (NMNZ M.62133)', Taguahelix subantarctica (Suter, 1909) (Punctidae), and Flammulina perdita (Hutton, 1883) (Charopidae). Some of these are primarily litter-dwelling snails, but they will colonise arboreal sites when moisture is persistent and the risk of desiccation is correspondingly low. The charopids of the genus Serpho Hutton, 1904 at around $10 \mathrm{~mm}$ shell diameter are the largest of the strictly arboreal snails found in New Zealand forests, and have a capacity to form a thin epiphragm. Athoracophoridae and Euconulidae may feed primarily at arboreal sites, but their activity is restricted to nocturnal periods of high humidity and they rest during the day in moist cervices that are primarily on the ground.

Gastropods evolving in very wet habitats often 'sacrifice' the protection offered by possession of a shell for the mobility, fast body movements and ability to occupy very small spaces afforded by the reduction or elimination of the shell. This evolutionary trend in shell reduction, and thus transition from being a snail to a slug in body form, has occurred in many regions of the world, and in many land snail families. Indeed, in many regions slugs make up a significant part of the land snail fauna (Solem, 1974; Barker, 2001). In New Zealand the evolutionary trend towards the slug form is apparent in several genera of Charopidae and Rhytididae as semi-slugs - the shell is reduced to the extent that the animal can no longer withdraw into it, and in Athoracophoridae, full slugs with the vestigial shell internalised and represented by a series of calcareous granules. The charopid and rhytidid semi-slugs exhibit little tolerance to 
desiccation and are restricted to microenvironments of high humidity on the forest floor, although Ranfurlya constanceae Suter, 1903 of the subantarctic Auckland Islands is active on low-growing vegetation. Athoracophoridae have a more robust water-conservation behavioural repertoire and ureter design, and can occur in a range of vegetation types from grasslands to forest, and in all tiers from the litter on the ground to the upper canopy. Animals often aggregate during the daytime in the vicinity of the small pools of water and wet humus trapped in the leaf axils of large monocotyledenous plants such as cabbage trees (Cordyline spp., Agavaceae), perching lily (Collospermum hastatum, Asteliaceae), flax (Phormium tenax, Agavaceae), kiekie (Freycinetia baueriana, Pandanaceae), and the nikau palm (Rhopalostylis sapida, Palmae), in addition to moist litter. They also display huddling behaviour (see Cook, 2001), where a number of animals aggregate in a tight group to create a humid micro-climate, thus making conditions more favourable to their survival when the ambient air is dry.

The majority of New Zealand land snails have life-styles revolving around moist micro-crevices in the litter of the forest floor. The quality of the available spaces amongst the leaves and their decay products seems to be important with many species exhibiting definite preferences for crevice types. Even the rather recalcitrant litters such as that of kauri (Agathis australis, Araucariaceae), rimu (Dacrydium cupressinum; Podocarpaceae), totara (Podocarpus spp.; Podocarpaceae), rewarewa (Knightia excelsa, Proteaceae), and kanuka (Kunzea ericoides, Myrtaceae) can support snails in abundance. While a number of species exhibit great ecological flexibility, with broad microhabitat preferences across a range of textural and moisture conditions of the litter, the majority of New Zealand land snails evidently have specific requirements. As a general rule, in leaf litter the larger snail species, over $5 \mathrm{~mm}$ shell diameter, tend to be surface-rovers and occupy "big" spaces in the loose leaf and twig jumble in the upper litter, while small species, $<3$ mm shell size, tend to occur towards the litter base, amongst the fine, particulate products of decomposition. Most species in these litter dwelling communities are very patchily distributed over a sub-meter scale, reflecting the patchy distribution of litter of the requisite quality. Several species may be rather uncommon or rare over most of their range, but can be abundant, and even dominate communities, in particular situations.

The habitat space for forest floor species, especially those of the upper litter layers, can be substantially increased where a jumble of coarse debris accumulates. The fallen dead fronds of nikau palm are an example, with species such as Allodiscus dimorphus (Pfeiffer, 1853), Fectola mira
(Webster, 1908), Laoma marina (Hutton, 1883), Phrixgnathus poecilosticta (Pfeiffer, 1853), Otoconcha dimidiata (Pfeiffer, 1853), Phenacohelix giveni Cumber, 1961, Ph. ponsonbyi (Suter, 1897), Liarea egea (Gray, 1850), L. hochstetteri carinella (Pfeiffer, 1861), Thalassohelix ziczag (Gould, 1848), and the rhytidid Delos coresia (Gray, 1850), especially favouring this microhabitat in many lowland forest areas of the North Island. Under moist conditions snails shelter where the frond sheath rests close to the ground, or when moisture is excessive, they may crawl up inside the rolled sheaths. During extended dry periods, these nikau sheaths are vacated and the snails retreat to the litter below. The piles of debris created by the fallen fronds of tree ferns (Cyatheaceae) provide rather different conditions, with that of Mamaku tree fern (Cyathea medullaris) favouring species with a liking for wet conditions, including a number of charopids and punctids that utilize the slimy cavities within the decaying stems. The piles of litter from the tree ferns Cyathea dealbata, C. cunninghamii and various Dicksonia species favour land snails with preference for drier conditions. Deep cumulations of debris provide conditions suited to larger species of the predatory Rhytididae. Living trees of kauri and some podocarps (such as rimu) shed a lot of bark and this corticous debris can also harbour a range of snails, especially charopids such as Phenacharopa pseudanguicula, Climocella mayhillae Goulstone, 1996, Aeschrodomus stipulata (Reeve, 1852) and Charopa coma (Gray, 1843).

A range of other microhabitats is available to land snails in forests. Litter and humus suspended above the ground - in epiphytes, in lianes such as kiekie, in the crowns of nikau and tree fern, and in forks of tree branches - supports a range of land snail species. The majority of these species also occur on the ground and thus the suspended litter simply represents a vertical extension of their usual habitat. Only a few species, such as the punctids Kokikora angulata Climo and Goulstone, 1995 and 'Punctidae sp. 59 (NMNZ M.65253)', and the charopids Charopa bianca (Hutton, 1883), Huonodon pseudoleiodon (Suter, 1890) and H. hectori, tend often to be more prevalent in the suspended litter than on the ground. Large carnivores such as species of Paryphanta Albers, 1850, Rhytida von Martens, 1860, and Schizoglossa Hedley, 1892 will occasionally venture into arboreal sites in search of prey. The trunks of trees and shrubs represent a transitional habitat between the ground litter and the arboreal foliage and suspended litter habitats. Accordingly the land snail communities found on trunks tend to have much in common with those in litter. Moeed and Meads (1983) showed that, in the Orongorongo Valley near Wellington, different tree species tend to have rather different faunas associated with their trunks. This reflects the 
differences in the texture of the trunks among tree species. Those with relatively smooth trunks are more suited to the 'creeping over a bed of mucus' style of locomotion in snails. Species such as Athoracophorus bitentaculatus (Quoy and Giamard, 1832) use such trunks as routes for their nocturnal feeding excursions to and from the upper trunk and canopy. The smooth bark also supports a film of bacterial, fungal and algal growth that provides an ideal feeding substrate for snails whose mouth parts are best equipped to grazing on biofilms and particulate matter from smooth surfaces. In contrast, trees with rough trunks are not particularly suited to the locomotor activity of snails, but often provide an abundance of crevices in which small snails can take up residence and from which they can make short nocturnal excursions to graze on fungi, algae and lichens. Species that exhibit some specalisation for the tree trunk niche include Paralaoma miserabilis (Iredale, 1913), Pasmaditta jungermanniae, Phrixgnathus ariel Hutton, 1883, Ph. compressus (Suter, 1909), Ph. viridulus (Suter, 1909), 'Punctidae sp. 173 (NMNZ M.61625)', 'Punctidae sp. 244 (NMNZ M.75477)' (Punctidae), Allodiscus planulatus (Hutton, 1883), Fectola mira, F. unidentata Climo, 1978, Flammulina perdita (Hutton, 1883), and Phenacharopa pseudanguicula (Charopidae).

Coarse woody debris in the form of dead standing trunks, and logs on the ground similarly have faunas which overlap with the litter communities. Nonetheless, the strong association of a number of species with this resource, dominated by members of the family Charopidae, gives the communities of woody debris a distinctive character. Furthermore, this character changes with the stage of decay of the wood. A number of land snails exhibit strong affinities for the cavities that occur under bark Paralaoma sericata (Suter, 1890) and Phrixgnathus brunneus Climo and Goulstone, 1993 among Punctidae, and Cavellia anguicula (Reeve, 1852), C. bianca, C. Coma, Charopa montivaga Suter, 1894, Ch. pilsbryi (Suter, 1894), F. unidentata, H. hectori, Huonodon microundulata (Suter, 1890), Loistholon benhami (Suter, 1909), and P. pseudanguicula among Charopidae. For these bark dwellers, tawa (Beilschmiedia tawn, Lauraceae), taraire (B. tarairi) and rimu logs are their pre-eminent choice for the bark lifts cleanly away from the trunk during the early stages of decay. Huonodon hectori can be particularly abundant - when the log is at the right stage of decomposition this species can be present in hundreds per square metre of log surface. Other typical log habitat species are Allodiscus tessellatus Powell, 1941, Cavellia buccinella (Reeve, 1852), C. sterkiana (Suter, 1891), Cavellioropa huttoni (Suter, 1890), C. moussoni (Suter, 1890), C. subantialba (Suter, 1909), C. coma, Climocella akarana Goulstone, 1996, Fectola infecta (Reeve, 1852), Flammocharopa montana (Suter, 1891), Flammulina zebra (Le Guillou, 1842), H. pseudoleiodon, Mocella eta (Pfeiffer, 1853), Phacussa helmsi (Hutton, 1882), Therasiella celinde (Gray, 1850) and Thermia cressida (Hutton, 1883). Some litter dwelling snails are especially abundant in the friable debris that accumulates under and adjacent to large logs in the advanced stages of decomposition - notably Charopa ochra (Webster, 1904). Some species simply shelter under logs and as such this woody debris simply represents an extension of the coarse material in the upper litter layers.

The majority of New Zealand land snails are detritivores. They feed preferentially on the microorganisms associated with decay, rather than on the dead plant material per se. Arboreal taxa are primarily grazers of phylloplane micro-organisms. A notable feature of the New Zealand fauna, relative to many continental areas, is the absence of herbivores - only juveniles of $P$. hongii exhibit any great tendency to feed primarily on green plant tissues. Nonetheless, detritivory or phyllophagy in New Zealand members of Hydrocenidae, Pupinidae, Achatinellidae, Athoracophoridae, Bulimulidae, Charopidae, Euconulidae, Punctidae, Succineidae and Vertiginidae is entirely consistent with the predominant feeding behaviour of their extralimital relatives and thus suggests that the constraint has a phylogenetic basis. It is interesting to speculate that the absence of herbivorous land snail families, and lack of development of herbivory in the resident families, may be associated with the predominance of ferns and woody perennial plants with well-defended foliage in New Zealand forest systems. Although New Zealand has had a long history of local and regional disturbances associated with factors such as volcanism, tectonic activity, flooding and wind, the indigenous flora has few species that aggressively colonise primary or secondary successional sites (Lee, 1998). There is a general absence of annual herbaceous plants in the flora (Lee, 1998). Often early successional plant communities are dominated by woody shrubs in the Myrtaceae genera Leptospermum and Kunzea. Only under high fertility conditions are early successional communties diverse, but are still dominated by woody perennials. The absence of land snail herbivory on elements of the large flora of herbaceous perennial plants is remarkable, but there is anyway a general spatial incongruence between habitat of these plants and that of most snails. The near absence of indigenous land snail species in areas subject to anthropogenic disturbance (Barker, 2002) asserts to the dependence of the New Zealand fauna on retention of a humus layer buffered from the weather by vegetation cover. Nekola (2003) documented similar sensitivities in North American land snails. Disturbed sites in New Zealand are readily 
colonised by adventive, European land snails. The prevalence of species from diverse phylogenetic parentage with pioneer or 'weedy' characteristics in the European fauna contrasts markedly with the low prevalence of 'weediness' and limited ability to colonise disturbed sites in the New Zealand fauna.

\section{Shell morphospace patterns}

Studies from various parts of the world have shown that variation among species in the shell spire index, defined as the ratio of shell height to shell diameter, is not randomly distributed. In most faunas, the spire index exhibits a bimodal distribution, with most, if not all species falling either into the high-spired mode (possessing a tall shell) or a low-spired mode (subglobular to flat shell) (Cain, 1977, 1980, 1983; Heller, 1987; Cameron and Cook, 1989; Roth, 1991: Cowie, 1995). Further, there is some evidence that different clades tend to occupy different positions in the spire index morphospace when they coexist in a region, but each occupies more of the total morphospace when they do not coexist (Cain, 1981). That is, in the absence of potential competitors, families may then exhibit diversification/radiation to fill a greater portion of the spire index morphospace. Cain (1977, 1983) suggested that shell shape is evolutionarily tied to niche characteristics, and raised the question of how families come together and share out the ecological opportunities.

Cain $(1978,1983)$ suggested that the differences in shell morphospace are related to the preferred angles of inclination on which the snails crawl, and that these angles might be related to the mechanisms of carrying a shell of a certain shape (see also Emberton, 1994). There is some empirical support for this hypothesis from field obervations and laboratory experiments (Cain and Cowie, 1978; Cameron and Cook, 1989; Cowie, 1995). However, there are numerous contradictory examples, such as semi-arboreal and arboreal species that possess shells with a low spire (e.g., Chiba, 2002). Thus, a compelling case for a single ecological dimensionality to the observed dispersion of the spire index has not yet been made. Cameron (1988) and Cameron and Cook (1989) used Cain's analysis of the dichotomy between low and high spired species in faunas to argue for empty functional

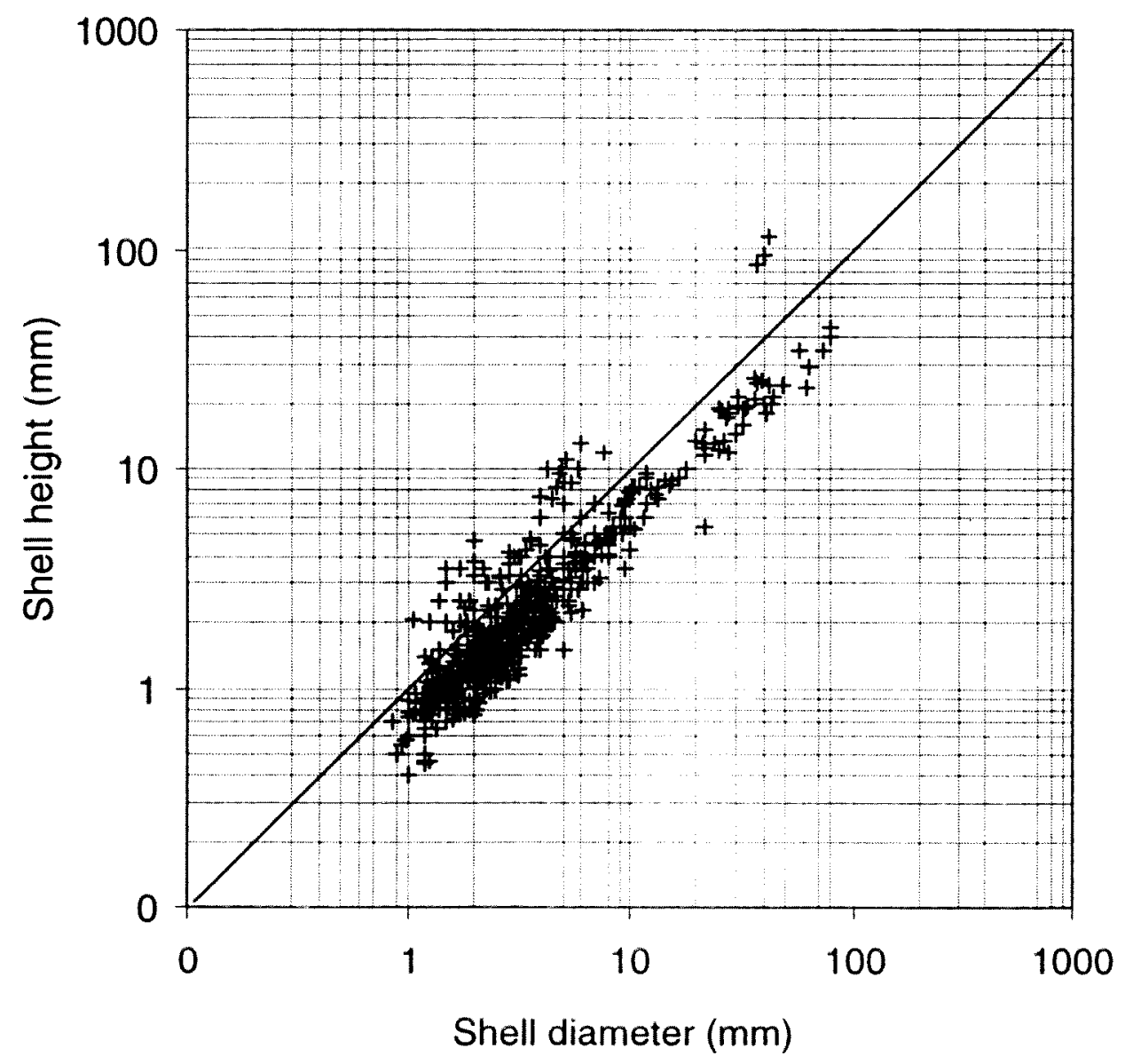

Figure 6 The distribution of the shell spire index for the land snail species of New Zealand, plotted on logarithmic scale as shell diameter $(\mathrm{mm})$ on shell height $(\mathrm{mm})$. Excluded are the Ellobiidae (marine littoral to supralittoral), Hydrobiidae (aquatic, with 2 species occasionally semi-terrestrial), Assimineidae (marine littoral to supralittoral) and Athoracophoridae (terrestrial slugs, with internal, granulated shell). The diagonal line is the line of equidimensionality (shell height $=$ shell diameter). 
niches in regional faunas, and they attempted to account for the vacancies in terms of environmental history.

A number of faunas have been noted for departure from the commonly observed pattern of bimodality in the dispersion of the spire index (e.g., Cowie, 1995), with the implication that there may be vacant niches. Solem and Climo (1985), Emberton (1995) and Barker and Mayhill (1999) have earlier noted the strong dominance in several New Zealand land snail communities by species with low-spired shells, and thus an essentially unimodal dispersion in the spire index. In an analysis of land snail communities of the Pukeamaru Ecological District of the North Island, New Zealand, Barker and Mayhill (1999) suggested that the underdispersion of shell shape has been constrained by limited phylogenetic diversity and/ or by convergence upon successful adaptations.

Figure 6 illustrates the pattern of shell morphospace for the entire New Zealand land snail fauna (excluding athoracophorid slugs). While strongly dominated by low-spired species, the fauna is not without some representation in the tallspired $(\mathrm{H}>\mathrm{D})$ and the globular $(\mathrm{H}=\mathrm{D})$ modes. While shell size ranges from 0.85 and $113 \mathrm{~mm}$, the majority of species possess a shell of between 1 and $10 \mathrm{~mm}$ in size. The mean shell size was estimated to be $5.21 \mathrm{~mm}( \pm 0.31 \mathrm{SE})$ and the mean $\mathrm{H}: \mathrm{D}$ ratio 0.71 $( \pm 0.07 \mathrm{SE})$. Families of land snails within the New Zealand fauna overlapped substantially in shell morphospace.

Assuming a link between shell morphology and animal ecology, the shell morphospace delineated by the global fauna may indicate functional niche opportunities available to regional faunas such as that of New Zealand. Figure 7 illustrates, for prosobranchs and pulmonates separately, the global niche space and the extent to which that space is occupied by New Zealand species. For prosobranchs, the New Zealand fauna occupies only about $1.92 \%$ of the global morphospace. For pulmonates, the corresponding figure is $5.71 \%$. It should be noted, however, that at the global scale, and indeed in most regional faunas, most of the morphospace is sparsely populated by species.

At the family level, the shell morphospace exhibited by New Zealand species broadly conformed to the pattern seen in extralimital species when shell height and shell diameter are the dimensions of interest (Figure 8). In Charopidae, Euconulidae and Punctidae the predominant shell form is low-spired, both in New Zealand and elsewhere. The evolutionary excursion into the high-spired mode is more evident in New Zealand charopid and punctid species than in extralimital species of these families, but not disproportionately to species richness. Ripley's $K(t)$-function values for New Zealand charopids indicated general
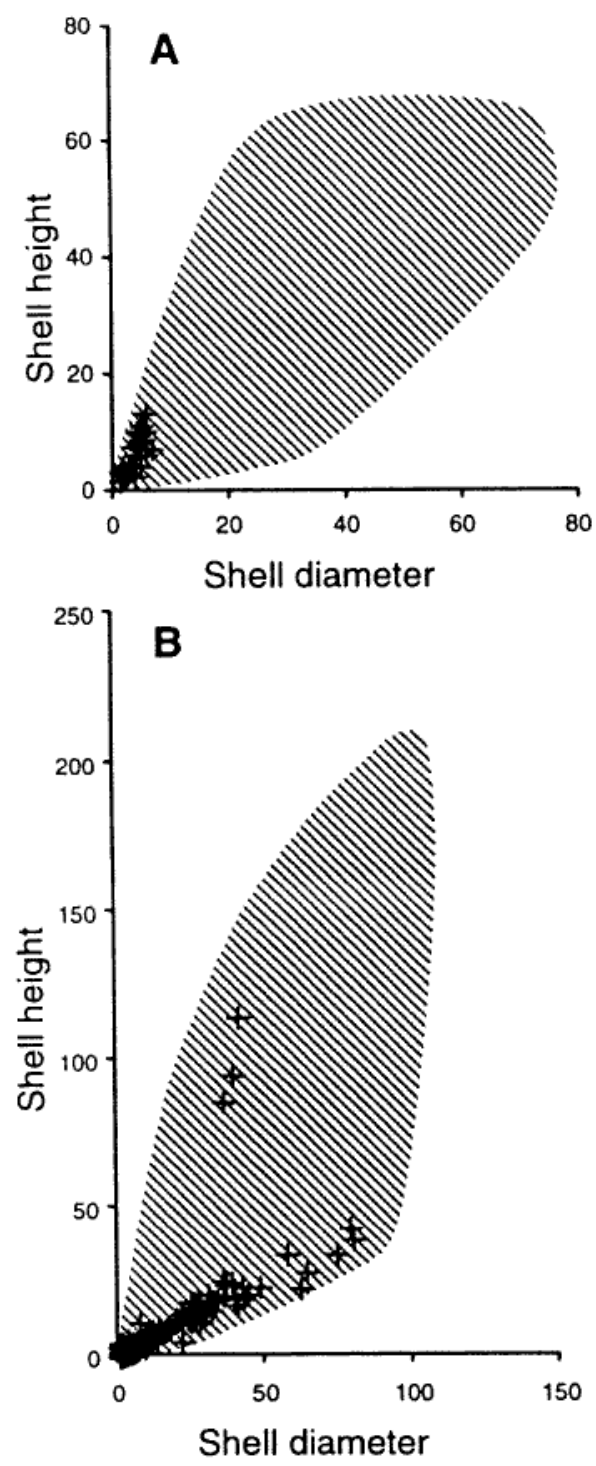

Figure 7 Shell morphospace delineated by the global land snail fauna (shaded eclipse), with pattern of occupancy of this space by species in the New Zealand fauna (+) indicated. (A) Prosobranchs. The global morphospace can be fully circumscribed by species in the following genera: Chondrocyclus (Cyclophoridae) (shell height $1.2 \times$ shell diameter $2.2 \mathrm{~mm}$ ), Cyclophorus (Cyclophoridae) $(65 \times 70)$, Hydrocena (Hydrocenidae) $(2.2 \times 1.6)$, Tropidophora (Pomatiasidae) (51 $\times 75$ and $30 \times 60)$, and Tomocyclus (Megalomastomidae) $(60 \times 23)$. (B) Pulmonates (excluding slugs). The global morphospace fully circumscribed by species in the genera Clavator (Acavidae) (shell height $145 \times$ shell diameter $40 \mathrm{~mm}$ ), Columna (Achatinidae) $(96 \times 19)$, Lissachatina (Achatinidae) $(210 \times 100 \mathrm{~mm})$, Megalobulimus (Acavidae) $(160 \times 95)$, Powelliphanta (Rhytididae) (40, 90), Tenuistomma (Urocoptidae) $(28 \times 4)$, Xenodiscus (Sagdidae) $(0.75 \times 0.75)$. Note the different presentation scales for the two taxonomic groups, and that the entire morphospace of the prosobranchs can be nested within the lower half of the pulmonate shell morphospace. 

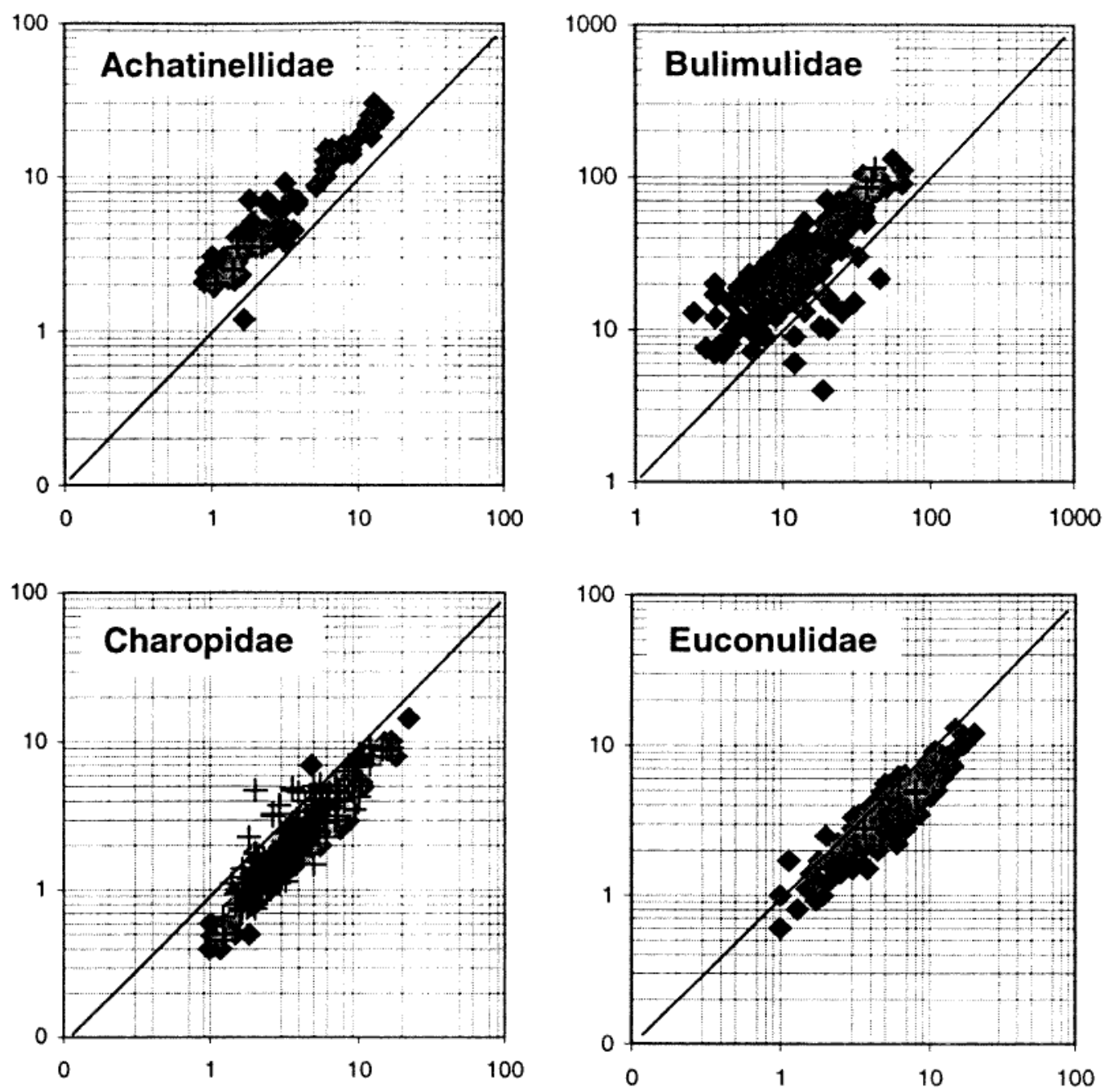

Figure 8 The distribution of the shell spire index among species of land snails in families represented in the terrestrial environments of New Zealand (+), overlaid on the spire index distribution of extralimital species within these families ( ). In each graph the abscissa is shell diameter (mm) (D) and the ordinate shell height (mm) $(\mathrm{H})$, each plotted on a logarithmic scale. Excluded are the Ellobiidae, Hydrobiidae, Assimineidae and Athoracophoridae. The diagonal line is the line of equidimensionality $(\mathrm{H}=\mathrm{D})$.

conformity to the dispersion in morphospace exhibited by extralimital charopids, except for a higher prevalence of shells less that $3.5 \mathrm{~mm}$ (Figure 9A). $K(t)$-function for the New Zealand punctids did not statistically depart from the pattern of dispersion in shell morphospace relative to the patterns seen in extralimital punctids (Figure 9B). In Achatinellidae, Bulimulidae, Pupinidae and Succineidae, where the predominant shell form is tall spired, there are cases globally of species bridging the assumed adaptive trough between $\mathrm{H}>\mathrm{D}$ and $\mathrm{H}<\mathrm{D}$ modes. In Pupinidae, this trend is perhaps more pronounced in the New Zealand fauna than elsewhere, but shell measurement data for the extralimital fauna were not available to test this quantitatively. For New Zealand and extralimital faunas alike, pattern of morphospace for Rhytididae and Vertiginidae is clearly unimodal. However, Ripley's K(t)-function analysis indicated that New Zealand rhytidids are over- dispersed through most of the H:D morphospace, relative to the extralimital members of the family (Figure 9C).

Shells of land snails are unreliable indicators of the nature of the animal. This is well known to systematists, but less well appreciated by ecologists. Not only do shells often vary tremendously within a species, they may exhibit evolutionary patterns of stasis or convergence during great anatomical (Emberton, 1988, 1991) and ecological (e.g., Barker and Efford, 2004) divergences. Thus care is needed in extrapolating information on shell morphospace to prediction of realised ecological niche. Charopids and punctids exhibit relative conservatism in shell morphology, yet there is ample evidence in New Zealand that congeneric species may exhibit considerable ecological and bionomic diversity. Goulstone (2001), for example, provided information on various habitat and niche preferences among members of the charopid 

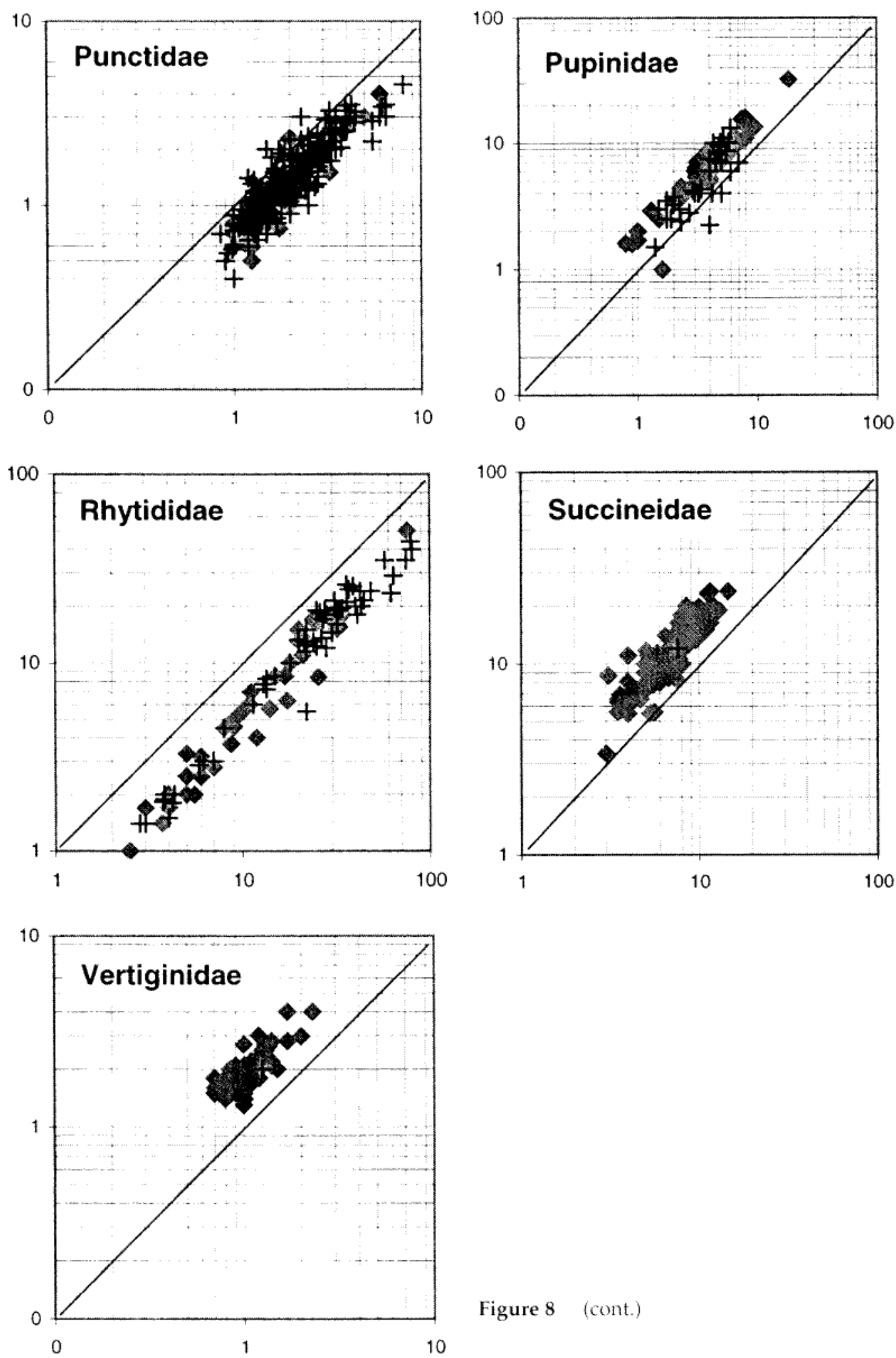

Figure 8 (cont.)

detritivore genus Phenacohelix Suter, 1892. Similarly, information on niche preferences among members of the charopid detritivore genus Climocella is presented in a series of papers by Goulstone (1995, 1996), Goulstone and Mayhill (1998) and Goulstone and Brook (1999), including the development in C. haurakiensis Goulstone, 1995 of a buccal anatomy suggestive of a facultative predatory feeding strategy. In Punctidae, the genus Tagualchix Powell,
1955 exhibits conservatism in conchological features, and the detritivore feeding strategy, yet these forest/shrubland species variously occupy litter and woody debris on the ground, mossy tree trunks, litter suspended in epiphytes and tree boles, and foliage at heights up to $10 \mathrm{~m}$ from the ground (Solem et al., 1981; Climo and Goulstone, 1993; F.M. Climo, unpublished manuscripts in NMNZ; G.M. Barker, unpubl.). 

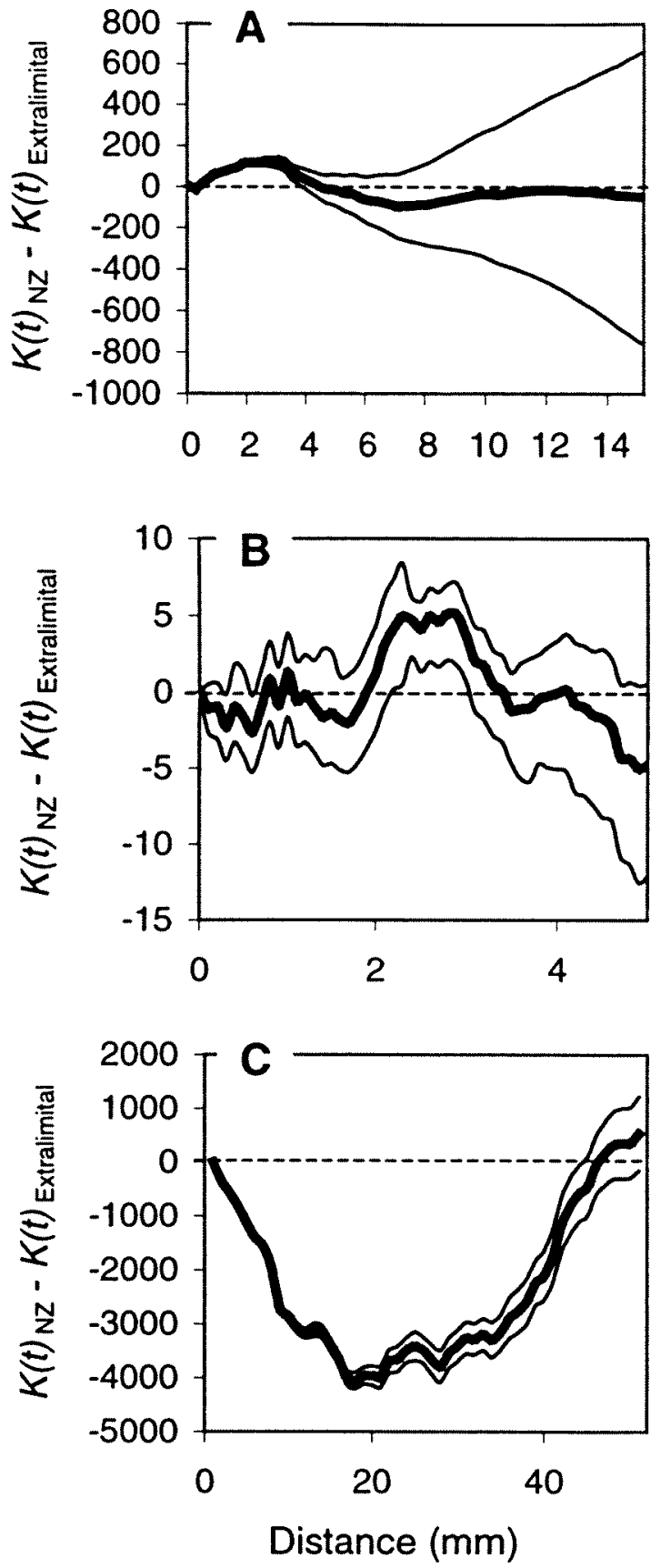

Figure 9 Occurrence pattern of New Zealand and extralimital land snail species in morphospace defined by shell height and shell diameter measurements. (A) Charopidae. (B) Punctidae. (C) Rhytididae. Solid line indicates the mean difference between the observed Ripley's K-function for the New Zealand species and the Ripley's K-function for extralimital species, dotted lines indicate $95 \%$ confidence envelope for this difference, dashed line indicates null hypothesis of no difference.

\section{Character of communities}

\section{Community structure}

The factors controlling relative and absolute abundances have not been explored in detail here because it is uncertain to what degree community structure has been modified by anthropogenic disturbances. The land snail communities were sampled in indigenous ecosystems, but all have been subject to predation by introduced vertebrates that have pervaded New Zealand ecosystems. The decline of several large-shelled snail species has been linked to the activities of these predators (e.g., Meads et al., 1984; Walker, 2003). However, the role of predation in structuring land snail communities has yet to be studied. In addition, introduced ungulate herbivores have significantly impacted on the vegetation over extensive areas of New Zealand. In a comparative study of community- and ecosystem-level conditions of New Zealand forested plots, fenced to exclude introduced browsing mammals, Wardle et al. (2001) found land snail communities in the litter were adversely affected by presence of these browsers.

RAD curves generated for species abundance data at the plot scale generally conformed to the lognormal model (Figure 10), with pronounced upward and downward curvatures at the extremities reflecting contributions from dominant and rare species, respectively. Only in some less species-rich plots (Figure 10A), generally associated with early successional shrublands of low floristic diversity, did the RAD curves approximate the geometric series. Some species-rich communities (Figure 10B) approached McArthur's broken stick model in the form of the RAD curves, with most of the species having similar abundances. Whittaker's $E c$ varied substantially between communities at the plot level, and this variation persisted in multiplot means at larger spatial scales such as environments and bioregions (not shown). However, this variation could not be shown to relate to measured environmental gradients, including floristic diversity.

\section{Alpha diversity}

Solem et al. (1981) highlighted the fact that small areas of forest (ca. $1 \mathrm{ha}$ ) in the Manukau Peninsula and other parts of New Zealand could support 40 60 (possibly as many as 72) land snail species. They indicated that these high levels of richness were maintained in sympatry to sub-meter scales. Barker and Mayhill (1999) showed that similar levels of species richness occurred in ca. $400 \mathrm{~m}^{2}$ plots of forest and shrubland in the Pukeamaru Ecological District of the North Island. In the present study ca. $400 \mathrm{~m}^{2}$ plots were again used as the focal scale of community assessment, but sampling encompassed communities over much greater geographic and environmental range.

Sampling at 931 plots using the F\&SSE regime in the present study yielded an average 17.1 species per plot. Sampling using only the SSE regime at 1,554 plots yielded an average species richness per plot of 20.2. The richness estimates at the plot level 

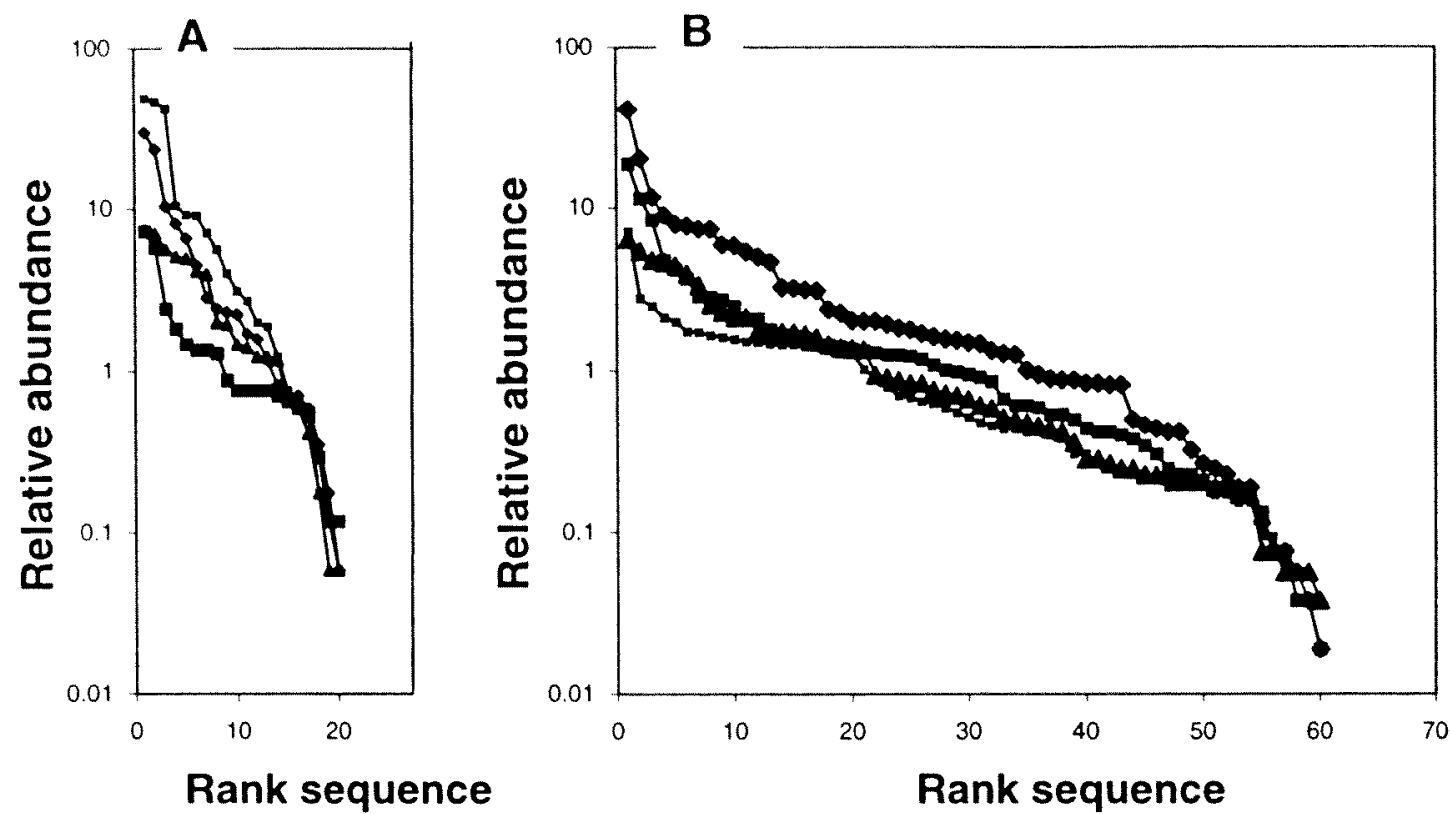

Figure 10 Relative abundance-species-rank-order (RAD) curves for land snail communities at the plot scale, selected arbitarily from data pertaining to four New Zealand bioregions and two levels of species richness (estimated by the F\&SSE sampling regime) to illustrate the predominant pattern. These RAD curves conform to the lognormal model of species abundances. (A) Plots with an estimated richness of 20 species. (B) Plots with an estimated richness of 60 species.

did not differ significantly between the two sampling regimes $(\mathrm{P}>0.05)$, and mean values simply indicate differences in the spatial dispersion of plots within geographic and environmental space. Species richness in the combined data set of 2,485 plots averaged 18.8 per plot (range 0 to 74 ). There was substantial variation within and among bioregions in richness at the plot level (Table 3; Figure 11), with means ranging from 0.2 species per plot in the Bounty Islands bioregion to 46.3 species for Western Waikato bioregion.

\section{Local-regional processes}

The mean proportion of plots occupied per species varied substantially among bioregions (Table 3). The variance of these estimates, as a proportion of the maximum possible variance, suggests that different assembly mechanisms have operated in different parts of New Zealand, or simply that the local communities in the various bioregions are at different states of disequilibrium in respect to the regional species pool. The national perspective provided by the additive partitioning the SSE data set indicated 18,18 and 65 percent contributions to total species richness from plot $(\alpha)$, environment $\left(B_{1}\right)$ and bioregion $\left(B_{2}\right)$ components, respectively (Figure 12). The observed contributions from plot and environment components were lower, and that from the bioregion component was higher than expected from null distributions of individuals among samples. Richness at the plot and enviromment scales was positively and linearly dependent on richness in the respective regional pools (i.e., at environment and bioregion scales) (not shown). The community assemblages were thus evidently derived from proportional sampling of the respective regional pools. The alpha and beta components contributed equally to species richness in the regional pool at the environment scale, while the beta component was dominant in the relationship between local richness at the environment scale and the regional pool at the bioregion scale (Table 4 ). Within bioregions, the additive partition of species richness in the SSE data showed that the contributions from plot $(\alpha)$ and environment $\left(B_{1}\right)$ components varied substantially (Figure 13), suggesting intra-archipelago influences on community structure.

The national perspective gained from additive partition of the F\&SSE data set into frame $(\alpha)$, plot $\left(B_{1}\right)$, environment $\left(B_{2}\right)$ and bioregion $\left(B_{3}\right)$ components is that bioregions were the dominant source of variation in species richness (Figure 14a). Furthermore, the observed contributions from frame, plot and environment components were lower than null expectations, while the contribution from the bioregion component was higher than expected (Figure 14a). Among bioregions, observed partitions of species richness across frame $(\alpha)$, plot $\left(B_{1}\right)$ and environment $\left(B_{2}\right)$ varied substantially (Figure 15A), further supporting the existence of strong intra-archipelago influences on community assemblage. Richness at the local scale of frame, plot and environment was positively and linearly 


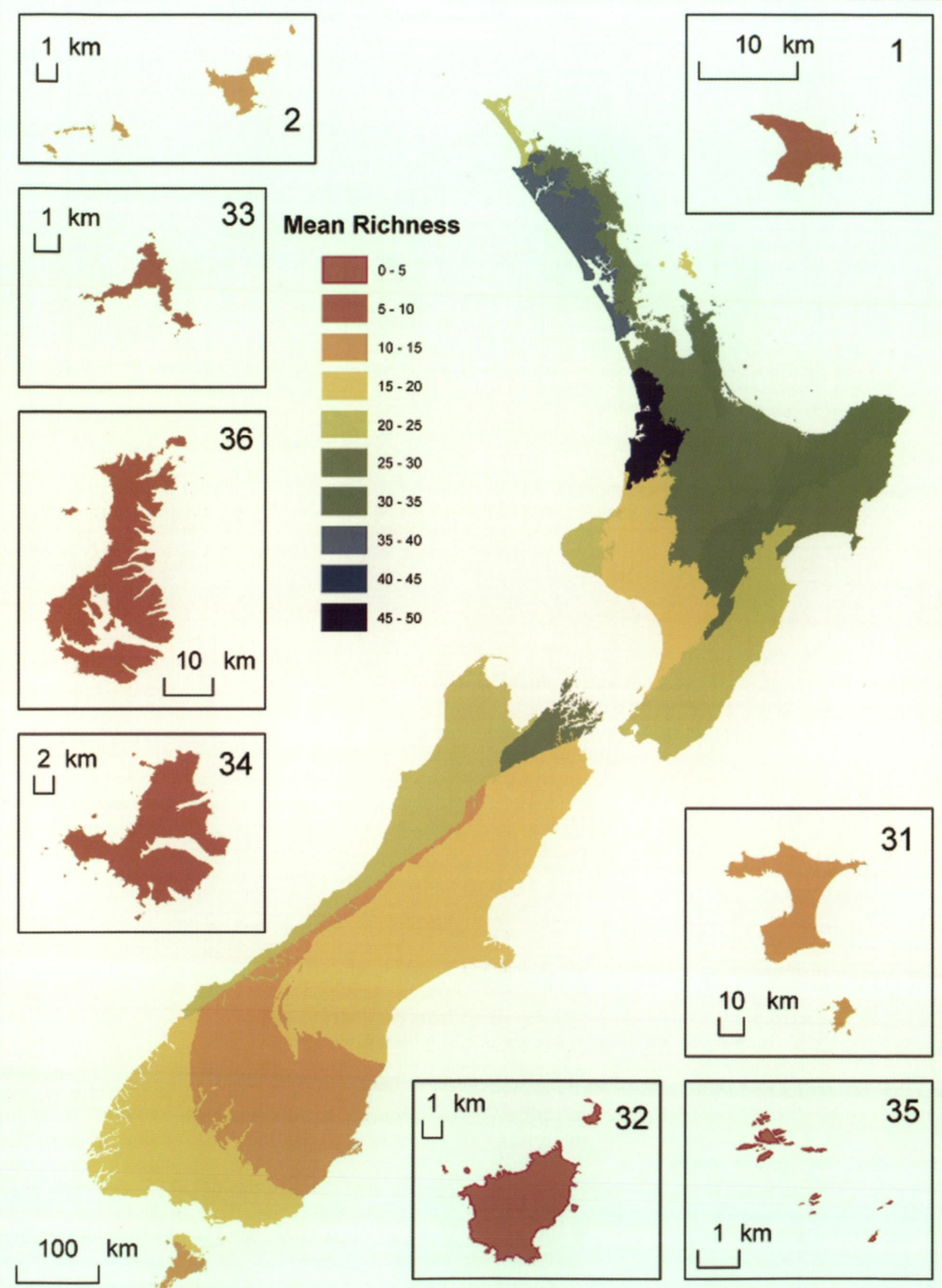

Figure 11 Spatial pattern in mean species richness per plot for land snails within bioregions of New Zealand. Values were derived from 2,485 plots dispersed across 36 bioregions. 
Table 3 Species richness and rate of occupancy by land snail species in 2,485 plots distributed in bioregions of New Zealand. Sampling by SSE and F\&SSE methods.

\begin{tabular}{|c|c|c|c|c|}
\hline \multirow{2}{*}{$\begin{array}{l}\text { Bioregion } \\
\text { Kermadec Islands-Raoul }\end{array}$} & \multirow{2}{*}{$\frac{\text { No. Plots }}{6}$} & $\begin{array}{l}\text { Mean (range) } \\
\text { richness } \\
\text { per plot }\end{array}$ & \multicolumn{2}{|c|}{$\begin{array}{c}\text { Proportion plots occupied per species } \\
\text { Mean } \begin{array}{c}\text { Proportion variance } \\
\text { achieved }^{1}\end{array}\end{array}$} \\
\hline & & $7.8 \quad(3-17)$ & 0.78 & 0.12 \\
\hline Three Kings Islands & 116 & $12.6 \quad(2-18)$ & 0.22 & 0.57 \\
\hline Aupouri & 75 & $22.5 \quad(2-38)$ & 0.12 & 0.22 \\
\hline Ruahine-Raukumara & 123 & $30.3(1-56)$ & 0.12 & 0.15 \\
\hline Hauraki-Auckland & 188 & $28.9(1-74)$ & 0.12 & 0.24 \\
\hline Western Northland & 194 & $37.6(1-54)$ & 0.08 & 0.14 \\
\hline Mokohinau Islands & 3 & $9.5(3-13)$ & 0.23 & 0.14 \\
\hline Poor Knights Islands & 4 & $12.0(3-16)$ & 0.76 & 0.72 \\
\hline Eastern Northland & 199 & $25.9(1-54)$ & 0.07 & 0.11 \\
\hline Barrier Islands & 28 & $18.4 \quad(2-38)$ & 0.13 & 0.13 \\
\hline Coromandel & 66 & $30.8 \quad(2-74)$ & 0.13 & 0.19 \\
\hline Western Waikato & 42 & $46.3 \quad(2-65)$ & 0.21 & 0.35 \\
\hline Taupo-Bay of Plenty & 136 & $27.8 \quad(4-54)$ & 0.13 & 0.21 \\
\hline Wairarapa-Hawkes Bay & 72 & $24.8 \quad(2-42)$ & 0.16 & 0.35 \\
\hline Hikurangi & 34 & $28.4 \quad(7-43)$ & 0.18 & 0.30 \\
\hline Taranaki & 32 & $20.5 \quad(4-38)$ & 0.16 & 0.19 \\
\hline Whanganui & 41 & $19.2(4-28)$ & 0.14 & 0.20 \\
\hline Rimutaka-Tararua & 49 & $21.2(6-34)$ & 0.15 & 0.18 \\
\hline Westland & 329 & $20.6(2-56)$ & 0.05 & 0.07 \\
\hline Fiordland & 76 & $17.8(4-40)$ & 0.11 & 0.10 \\
\hline Motueka & 52 & $22.5 \quad(5-48)$ & 0.14 & 0.20 \\
\hline Marlborough Sounds & 187 & $27.8 \quad(3-64)$ & 0.13 & 0.25 \\
\hline Kaikoura & 72 & $17.3(3-37)$ & 0.10 & 0.16 \\
\hline Canterbury Hills & 88 & $18.2(3-32)$ & 0.07 & 0.09 \\
\hline Canterbury Plains & 10 & $18.1 \quad(5-25)$ & 0.22 & 0.24 \\
\hline Chatham Islands & 19 & $12.6(1-39)$ & 0.31 & 0.22 \\
\hline Banks Peninsula & 8 & $15.6(7-13)$ & 0.32 & 0.61 \\
\hline Otago-Southern Alps & 84 & $14.4(1-23)$ & 0.07 & 0.08 \\
\hline Southland & 52 & $16.1(3-23)$ & 0.10 & 0.14 \\
\hline Stewart Island-Brook Street & 54 & $15.7(3-25)$ & 0.18 & 0.26 \\
\hline Stewart Island-Tuhua & 15 & $13.6(2-19)$ & 0.20 & 0.18 \\
\hline Snares Islands & 3 & $5.5(2-7)$ & 0.72 & 0.24 \\
\hline Auckland Islands & 16 & $9.5(2-11)$ & 0.33 & 0.60 \\
\hline Campbell Islands & 5 & $5.0(3-7)$ & 0.47 & 0.76 \\
\hline Antipodes Islands & 2 & $1.0(0-2)$ & 0.50 & 0.50 \\
\hline Bounty Islands ${ }^{2}$ & 5 & $0.2(0-1)$ & 0.20 & - \\
\hline Mean & & 18.8 & 0.22 & 0.26 \\
\hline
\end{tabular}

1. Variance in numbers of plots occupied per species expressed as proportion of the maximum variance possible given species distributed non-randomly between some occurring ubiquitously, others occurring in only one plot.

2. Only 1 species represented in the plots from the Bounty Islands Bioregion.

dependent on richness in the respective regional species pools (i.e., at plot, environment and bioregion scales) (not shown), and the contribution from the beta component increased with scale (Table 4).

When floristic diversity groups where used as a hierarchical level in the analysis of the F\&SSE data, rather than environment types, similar partition patterns of richness (Figures $14 \mathrm{~B}$ and 15B) were apparent. However, the form of the relationship between richness at the floristic diversity group scale and the regional pool at the bioregion scale was found to be curvilinear, suggesting a saturating phenomenon.
On average, $70 \%$ of the species richness at the plot level $\left(400 \mathrm{~m}^{2}\right)$ in the F\&SSE data was represented within a single frame (i.e. at the scale of $0.086 \mathrm{~m}^{2}$ ) (Figures 14 and 15).

\section{Environmental gradients}

Ordination and PCC analyses were used to provide insights into biogeographic and environmental gradients that may have a role in determining community structure. The ordinations of the SSE and F\&SSE datasets (the latter restricted to litter dwelling component of the communities) yielded quantitatively similar results, so only the latter is presented (Figure 16). Essentially the same 
Dlot aEnvironment $\mathbb{Q}$ Bioregion

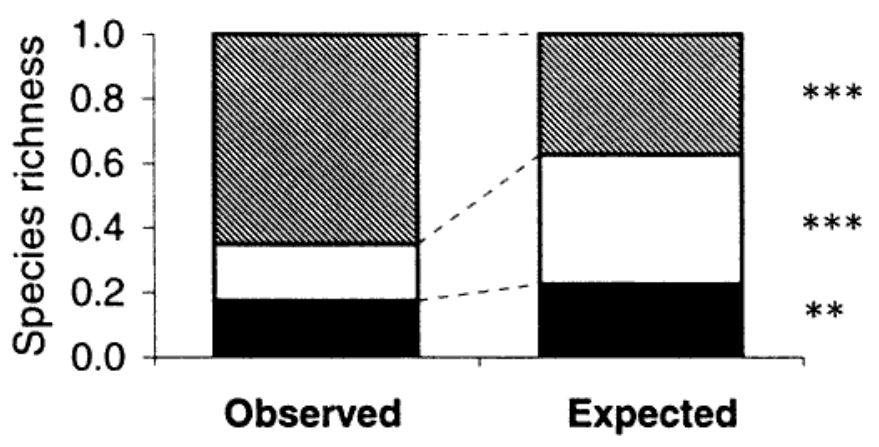

Figure 12 Observed and expected additive partition of species richness in New Zealand land snails, estimated by the SSE sampling regime, into plot $\left(\beta_{1}\right)$, environment $\left(\beta_{2}\right)$ and bioregion $\left(\beta_{3}\right)$ components. Values are expressed as proportion of total diversity of snails contributed by each level in the hierarchy. The expected values were derived from randomization of individuals. ${ }^{* *}$ and ${ }^{* * *}$ indicate significant departures of observed from expected at $\mathrm{P}<0.01$ and $\mathrm{P}<0.001$, respectively.

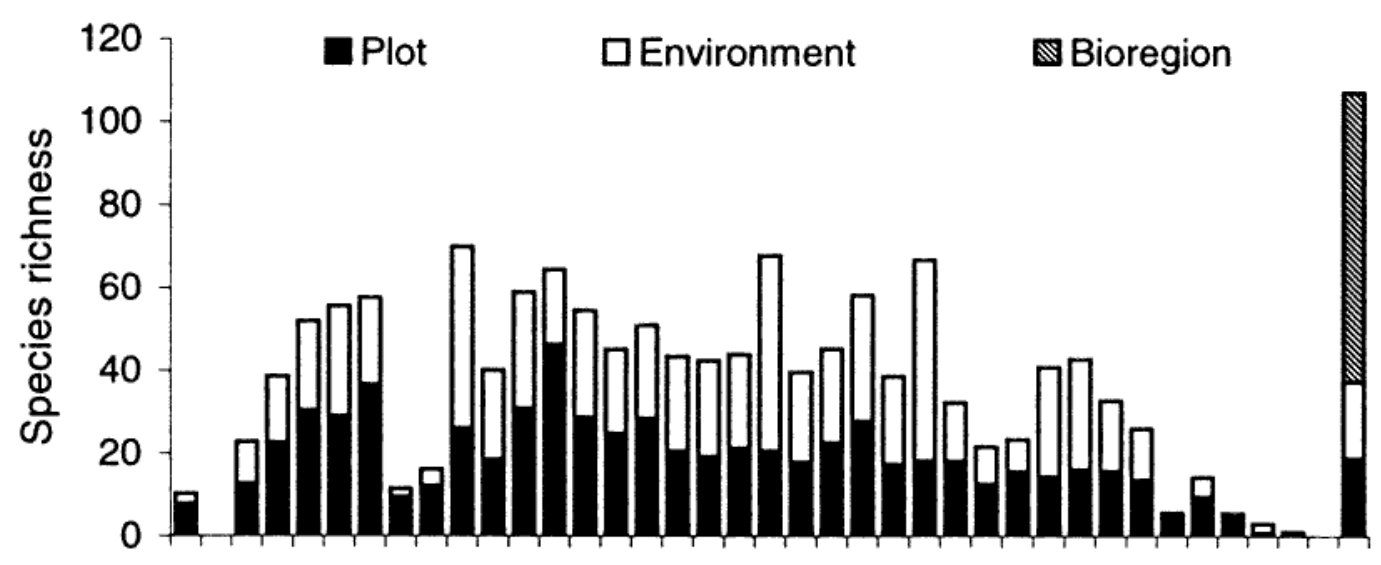

Bioregions

Figure 13 Additive partition of species richness in New Zealand land snails within bioregions, estimated by the SSE sampling regime, into plot $\left(\beta_{1}\right)$ and environment $\left(\beta_{2}\right)$ components. Bioregions are ordered left to right in approximate sequence of increasing latitude south, as in Figure 3. The bar to the extreme right of each graph indicates the additive partition of diversity across all bioregions, and includes the bioregion $\left(\beta_{3}\right)$ component.

set of macro- to meso-scale gradients significantly correlated with the first three axes of community variation in both ordinations - namely maximum age of residency of common ancestors, tree abundances in Fagaceae, Myrtaceae and Podocarpaceae, total tree species richness, mean minimum temperature of the coldest month, annual mean temperature, and annual solar radiation. The bioregion in which plots were located was highly correlated with the ordination. Litter mass and floristic diversity, recorded only for plots subject to the F\&SSE sampling regime, were also strongly correlated with the ordination space defined on the basis of litter-dwelling communities. The gradients associated with the soil environment were indicated to be of secondary importance.
Results from F\&SSE sampling indicated that at the plot scale, species richness (Figure 17A) tended to increase with floristic diversity. Taking spatial autocorrelation and area effects into account, regression analyses provided some support for floristic diversity as a deterministic factor in species richness as an emergent property of land snail communities at the plot scale. These regression models could account for 28 to $38 \%$ of the variation in richness among plots (Table 5). No other environmental variables, among the set documented for plots, could be shown to be significant predictors of richness at this scale, although inclusion in the models of solar radiation and abundances in some groups of trees did marginally increase the amount of variation explained. 
A

aframe $\quad$ Plot $\quad$ Environment $\mathbb{Q}$ Bioregion

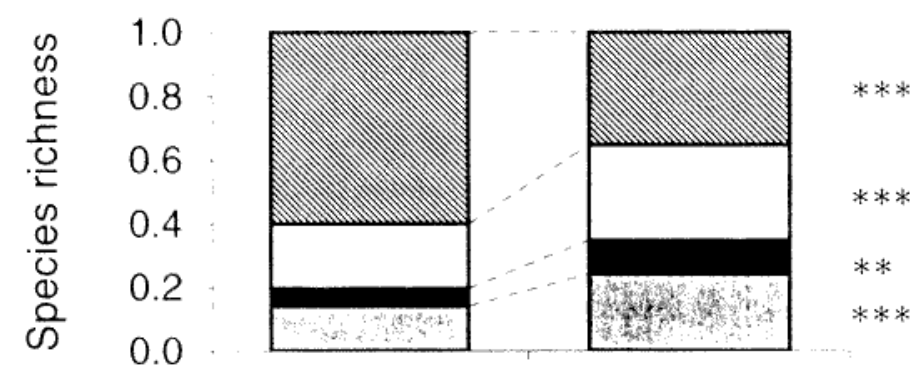

B

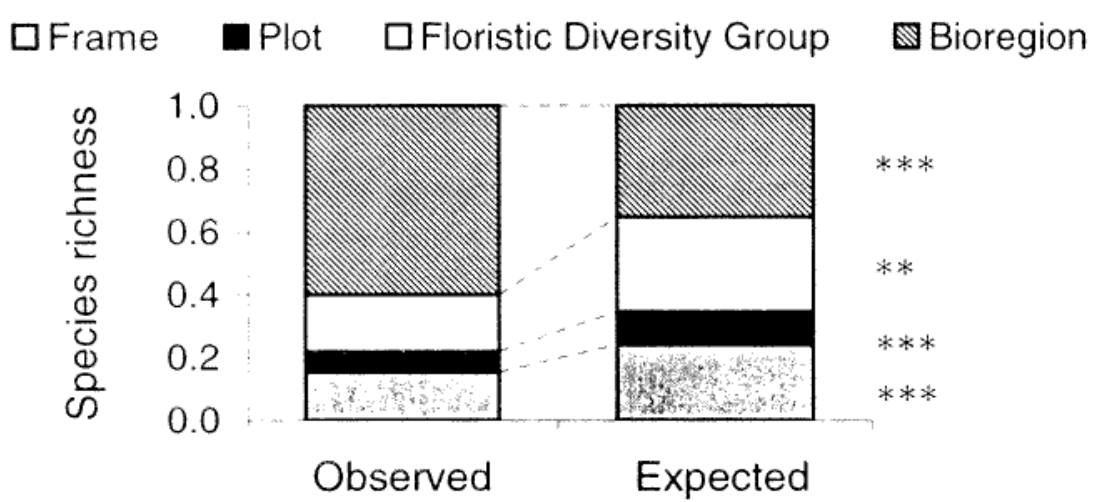

Figure 14 Observed and expected additive partition of species richness in New Zealand land snails, estimated by the F\&SSE sampling regime. (A) Partitioning into frame $(\alpha)$, plot $\left(\beta_{1}\right)$, environment $\left(\beta_{2}\right)$ and bioregion $\left(\beta_{3}\right)$ components. (B) Partitioning into frame $(\alpha)$, plot $\left(\beta_{1}\right)$, floristic diversity group $\left(\beta_{2}\right)$ and bioregion $\left(\beta_{3}\right)$ components. Values are expressed as proportion of total diversity of litter dwelling snails explained by each hierarchial level. The expected values were derived from randomization of individuals. ** and *** indicate significant departures of observed from expected at $\mathrm{P}<0.01$ and $\mathrm{P}<0.001$, respectively.

Table 4 Relationship of local species richness to the regional species pool size, with additive partition into alpha and beta components.

\begin{tabular}{|c|c|c|c|c|}
\hline \multicolumn{2}{|c|}{ Comparison } & \multirow{2}{*}{$\begin{array}{l}\text { Qualitative description of the } \\
\log \text {-log local-regional } \\
\text { relationship }\end{array}$} & \multirow[t]{2}{*}{ Alpha (\%) } & \multirow[t]{2}{*}{ Beta $(\%)$} \\
\hline Local & Regional & & & \\
\hline \multicolumn{5}{|l|}{ SSE sampling regime } \\
\hline Plot & Environment & Linear & 62 & 38 \\
\hline Environment & Bioregion & Linear & 30 & 70 \\
\hline \multicolumn{5}{|l|}{ F\&SSE sampling regime } \\
\hline Frame & Plot & Linear & 70 & 30 \\
\hline Plot & Environment & Linear & 61 & 39 \\
\hline Environment & Bioregion & Linear & 29 & 71 \\
\hline Frame & Plot & Linear & 70 & 30 \\
\hline Plot & Floristic Diversity Group & Linear & 53 & 47 \\
\hline Floristic Diversity Group & Bioregion & Moderately saturating & 33 & 67 \\
\hline
\end{tabular}




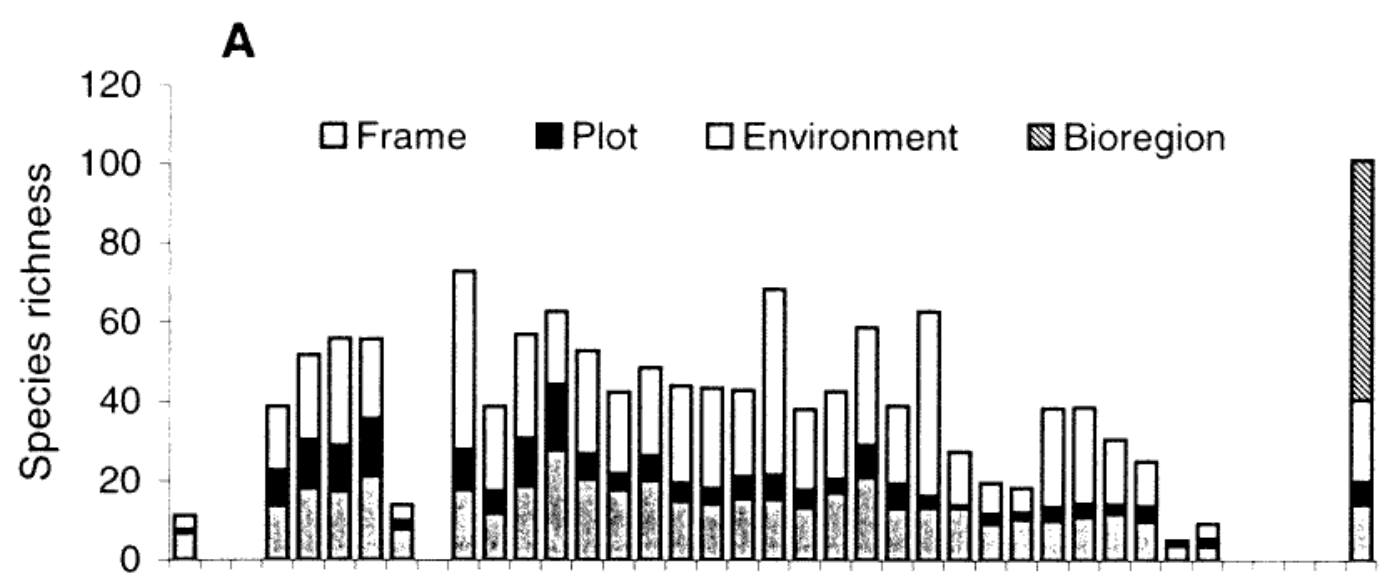

B

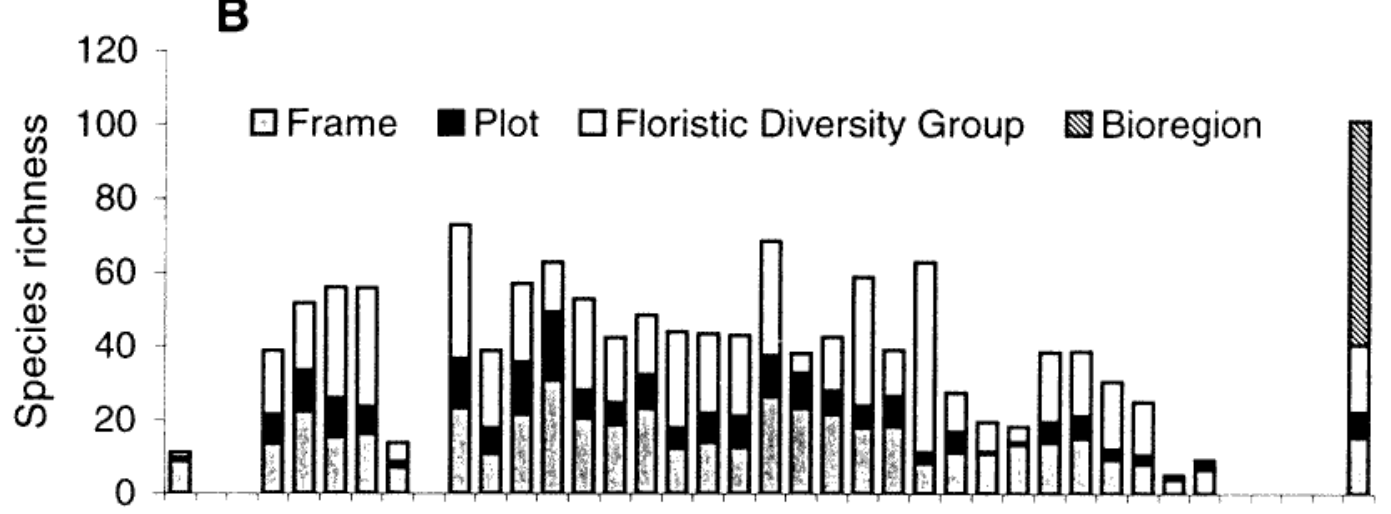

\section{Bioregion}

Figure 15 Additive partition of diversity in litter-dwelling New Zealand land snails within bioregions, estimated by the F\&SSE sampling regime. (A) Partitioning into frame $(\alpha)$, plot $\left(\beta_{1}\right)$, environment $\left(\beta_{2}\right)$ and bioregion $\left(\beta_{3}\right)$ components. (B) Partitioning into frame $(\alpha)$, plot $\left(\beta_{1}\right)$, floristic diversity group $\left(\beta_{2}\right)$ and bioregion $\left(\beta_{3}\right)$ components. Bioregions are ordered left to right in approximate sequence of increasing latitude south, as in Figure 3. The bar to the extreme right of each graph indicates the additive partition of diversity across all bioregions, and includes the bioregion $\left(\beta_{3}\right)$ component.

Regression analyses of the F\&SSE data further indicated a relationship between floristic diversity and variation in shell size of the land snail communities. This is illustrated for communities in the Waitakere Ranges, where sampling was conducted in 63 plots (Figure 17B-D). These diversity patterns suggest that small-shelled snails dominated communities in the Waitakere Ranges at early successional and other floristically poor sites, and that increased richness resulted from addition

Table 5 Coefficients of determination for the relationship between species richness of land snail communities in New Zealand and the environmental variables with the best fit at the plot scale. Species richness values $\log _{10}$ transformed prior to regression. All partial regression values reached significance after a sequential Bonferroni correction was applied.

Proportion of variance in species richness $\left(\mathbf{R}^{2}\right)$

Strongest single or multivariate models

\begin{tabular}{|c|c|c|c|c|}
\hline $\begin{array}{c}\text { Total } \\
(a+b+c)\end{array}$ & $\begin{array}{l}\text { Environment } \\
\text { only } \\
\text { (c) }\end{array}$ & $\begin{array}{c}\text { Spatially } \\
\text { structured } \\
\text { environmental } \\
\text { variation } \\
\text { (b) }\end{array}$ & $\begin{array}{c}\text { Space only } \\
\text { (a) }\end{array}$ & $\begin{array}{c}\text { Spatially } \\
\text { structured } \\
\text { environmental } \\
\text { variation and } \\
\text { space only } \\
(a+b)\end{array}$ \\
\hline $0.318^{* * *}$ & 0.141 & 0.070 & 0.010 & $0.177^{* * *}$ \\
\hline $0.347^{* * *}$ & 0.170 & 0.071 & 0.010 & $0.177^{* * *}$ \\
\hline
\end{tabular}


A

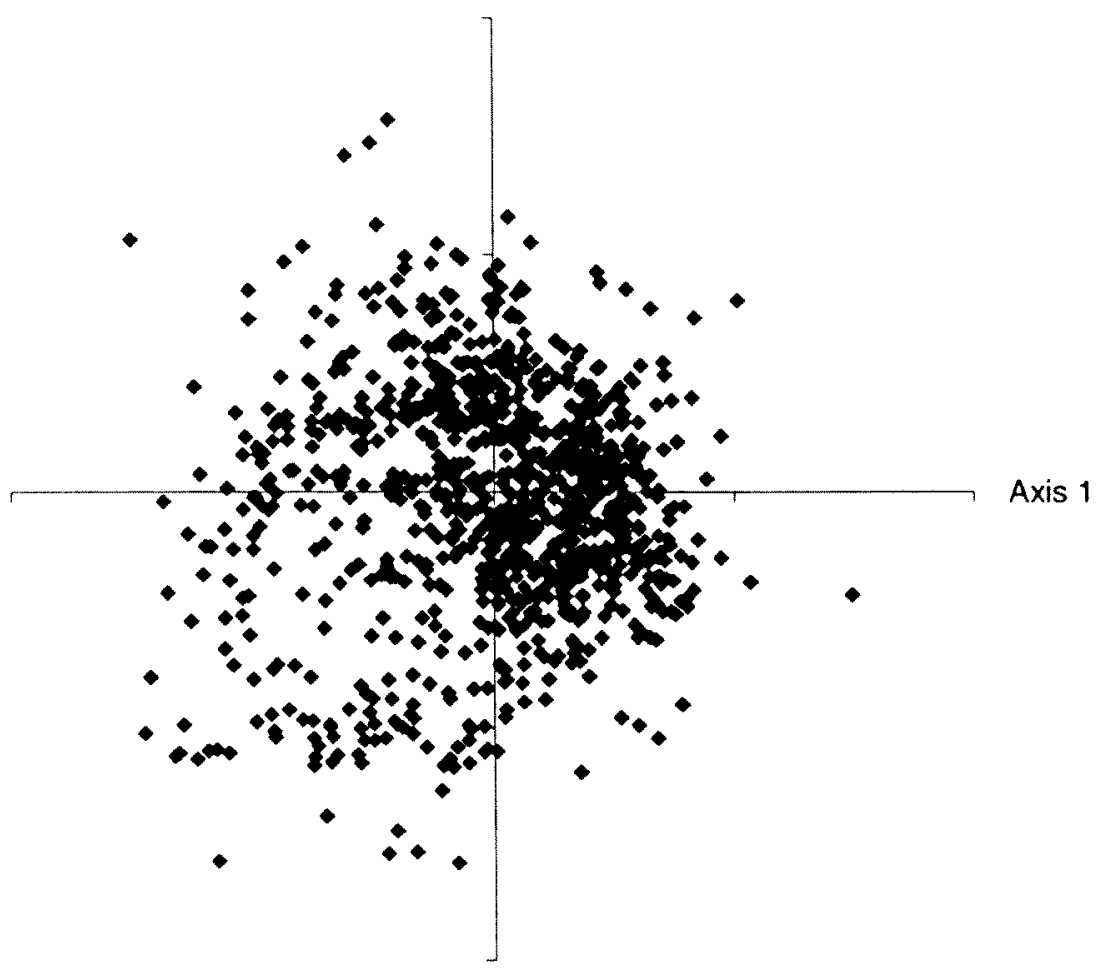

Axis 2

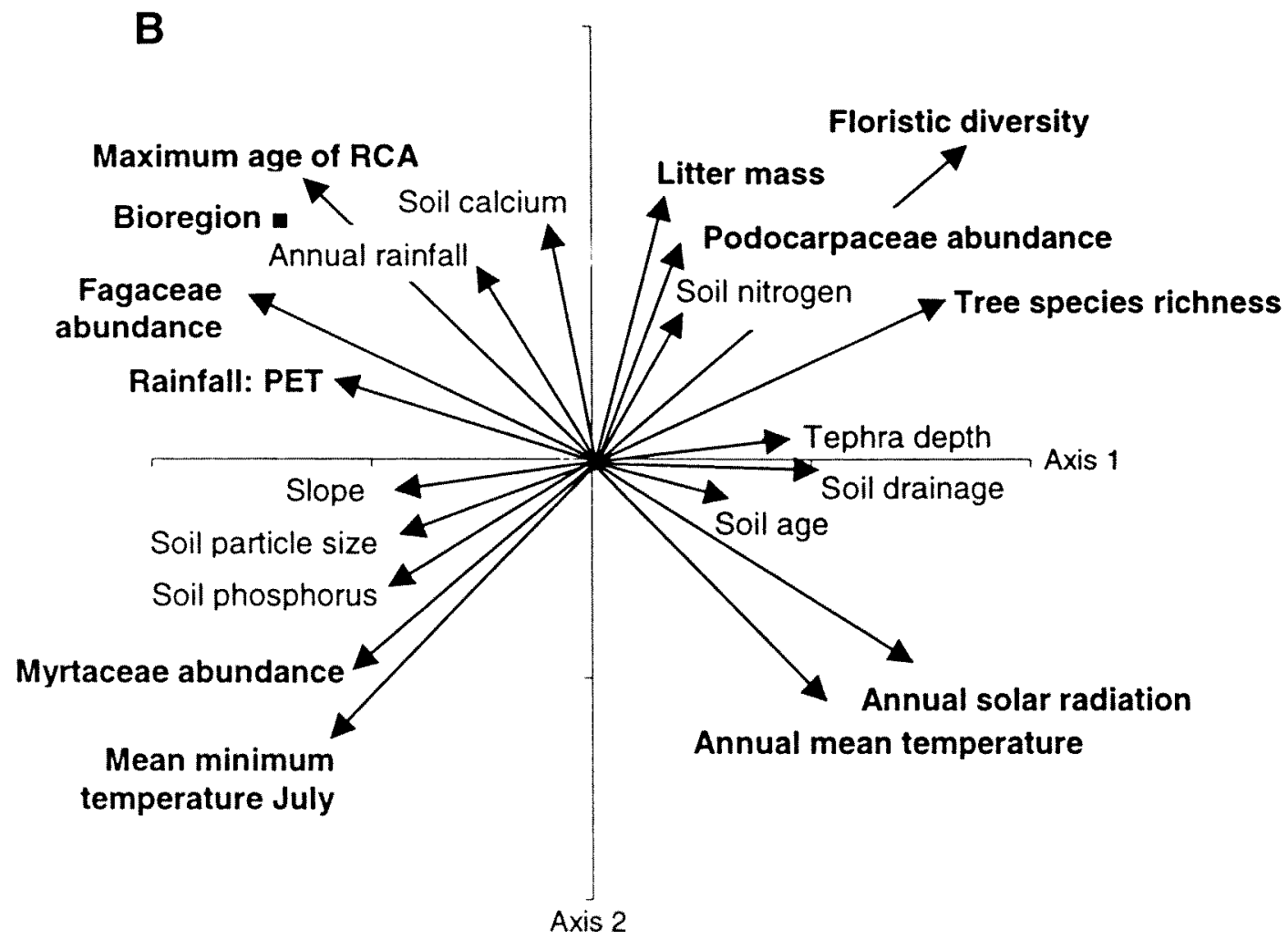

Figure 16 Semi-strong hybrid (SSH) ordination and principal component correlation (PPC) analyses of litter-dwelling New Zealand land snails communities estimated at 931 plots in New Zealand by frame sampling of litter. (A) SSH ordination of plots, depicted in the first two dimensions (stress values: 1 dimension $=0.305,2$ dimension $=0.135,3$ dimension $=0.023$ ). (B) Pattern of correspondence of environmental and biogeographic gradients with the ordination space identified by PPC analysis. Those gradients most strongly correlated with the first two axes of community variation $(\mathrm{P}<0.001)$ are highlighted in bold font. 

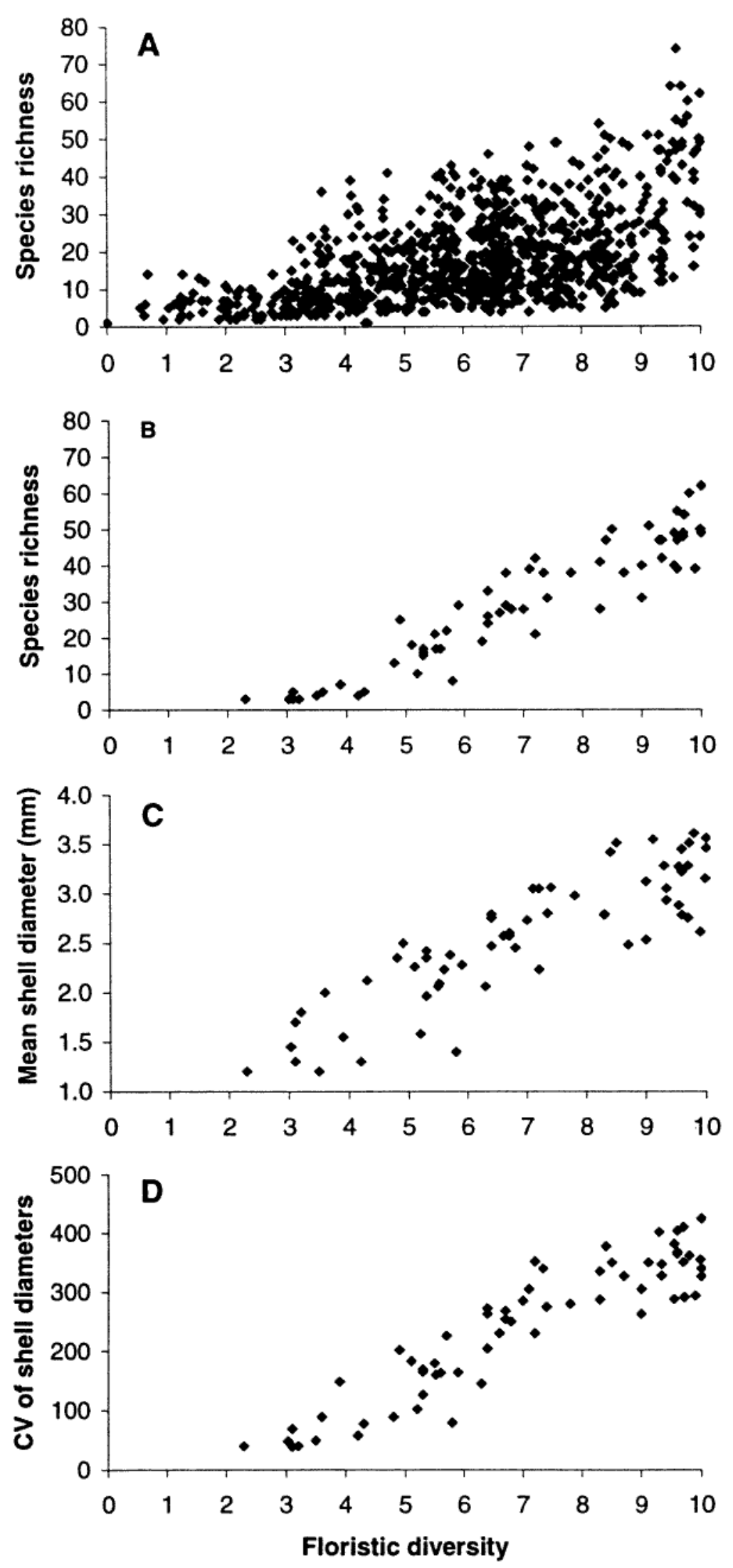

Figure 17 Emergent properties of New Zealand land snails communities at the plot scale in relation to the gradient of floristic diversity. (A). Variation in species richness in plots distributed across 32 bioregions. (B-D) Variation in species richness, mean shell size, and coefficient of variation in shell size for communities sampled at 63 plots in the Waitakere Ranges (Western Northland Bioregion). All plots sampled by the F\&SSE regime. 
of larger-shell snails into the communities. These results generally concur with those published earlier by Barker and Mayhill (1999), indicating that, at least within regional faunas, these patterns of community assembly may be widely applicable. However, similar patterns of shell size variation along the floristic diversity gradient could not be demonstrated for all regions of the country, suggesting the form and/or strength of the relationships between floristic diversity and shell size attributes at the community level varied spatially. The relationship between floristic diversity and mean shell size was found to be stronger $(P<0.05)$ for communities in bioregions with a low component of bioregion-endemic species (Bioregion Endemism Group IV; regression coefficient $0.203 \pm 0.056 \mathrm{SE}$ ) than in bioregions with a high component of local endemism (Bioregion Endemism Groups I-III; regression coefficient $0.082 \pm 0.094 \mathrm{SE})$.

\section{CONCLUSION}

\section{An emerging synthesis?}

Faunal composition and community structure are inextricably linked through the interdependence between regional and local diversity, which has its roots in historical processes. The New Zealand land snail fauna is depauperate at the family level, yet it is extraordinally rich at the species level. Most of the species diversity is contained within the families Pupinidae, Athoracophoridae, Rhytididae and, especially Charopidae and Punctidae, as the consequence of extensive endemic cladogenesis and speciation. We may enquire as to what the consequences of this evolutionary structure have been for community assemblage. Ecological theory suggests that alpha diversity may be related to levels of niche partitioning between species (Auerbach and Shmida, 1987). Congestion of the New Zealand species diversity in a small part of the niche space potentially available, as indicated by shell morphospace, suggests the likelihood of a strongly competitive environment. Yet we observe often high sympatric diversity, maintained down to at least the $0.086 \mathrm{~m}^{2}$ scale, and limited evidence for divergence among species in their shell morphology that would allow greater niche partitioning. While some systematic studies find strong evidence for allopatry of closely related species, this is not an invariant pattern in New Zealand and indeed in many communities we find several to many congeneric species. Further, Barker and Mayhill (1999) could find little evidence for competitive exclusion operating in land snail communities in the Pukeamaru Ecological District. Furthermore, the high density of individuals (up to $5,000 \mathrm{~m}^{-2}$ ) suggests that resource levels are also high, cautioning against use of resource-ratio models. Nonetheless, observations on how species are distributed at sites, including stratification and niche preferences within the litter (Climo, 1973; Solem and Climo, 1985; this study), and the relationship between floristic and snail diversity (Barker and Mayhill, 1998; this study), suggest that resource is a key factor.

Sampling over the entire geographic extent of the country, and in a large array of environment types, yielded a mean richness at the $400 \mathrm{~m}^{2}$ plot scale of 18.8 species. On this basis, New Zealand land snail communities are not dissimilar from those in many parts of the world. However, richness in this study varied considerably, ranging from 0 to 74 species per plot. Correspondingly, the rate of site occupancy per species varied substantially between bioregions - the overall mean of $22 \%$ sites occupied per species was inflated by exceptionally high values for some remote island systems. The New Zealand-average pattern is thus contrary to reports for some extralimital faunas that richness exhibits modest variation at the site (= plot) scale, with a high proportion of the regional fauna often represented at individual sites (e.g. Schmid, 1966; Nekola, 1999a; Nekola and Smith, 1999; Cameron and Pokryszko, 2004). Lack of constancy in richness in most bioregions suggests either that not all species have yet reached all suitable sites, or that there is a marked spatial heterogeneity in environmental quality and thus availability of niches. Only in some of the most isolated bioregions within the New Zealand archipelago was there a high level of saturation. Additive partition analyses confirmed the high contribution of bioregions, environment types and floristic diversity groups, as beta components, to variation in species diversity in the New Zealand landscape. We can expect high beta diversity when the fauna contains large or stenoecious species with poor powers of dispersal. That many species are small and have a wide geographic range (especially among charopids, punctids, achatinellids, and the sole hydrocenid) suggests high dispersive powers. The modest slope $(z)$ values in the regression of log-log species-island area relationship supports the view that intra-island radiation has been muted, secondarily, by dispersal within the archipelago.

Regression analyses indicate that local species richness is dependent upon regional richness in a manner consistent with proportional sampling (Cornell, 1993; Gering and Crist, 2002). Nonsaturating relationships are common in studies of local and regional richness across a diverse range of taxa (Srivastava, 1999), and are generally interpreted as evidence for non-interactive communities (Cornell, 1985; Caley and Schluter, 1997). Models of non-interactive or neutral communities indicate that density-independent 
fluctuations, limited dispersal abilities (Strong et al., 1984; Hubbell, 2001), and open niche space combined with random colonisation (Caswell and Cohen, 1993) can produce proportional sampling. We need to be cautious in our interpretation, however, as local interactions may simply not be strong enough to limit local richness (Cornell, 1993), and interactions among species can lead to linear forms of the local-regional richness model (Cornell and Lawton, 1992; Caswell and Cohen, 1993). Evidence for saturation in the present study was found when relating local richness at the scale of floristic diversity groups to the regional pool at the bioregion scale - again invoking resource and competition for it, as important in structuring communities. Indeed, the pattern of successive replacement of ecological equivalents is clearly evident in at least some bioregions in relation to the gradient of floristic diversity, where a few smallshelled snails dominate communities at early successional or floristically poor sites, and that increased richness results from addition of larger snails into available niches (Barker and Mayhill, 1999; this study). That diversity of the litterdwelling snails increases with floristic diversity is probably brought about by plant diversity determining microhabitat diversity in the litter. Wardle et al. (2001) and D.A. Wardle and G.M. Barker (unpubl.) documented a relationship between species richness in land snail communities and both diversity and quality ( $\mathrm{C}: \mathrm{N}$ ratio) of the litter in 30 forest plots distributed throughout New Zealand. Getz and Uetz (1994) earlier reported on a positive relationship between tree species richness of the leaf litter of forests in the southern Appalachian mountains, USA, and the richness of the land snails in that litter. However, this relationship is not universal, with Nekola and Smith (1999) for example, unable to detect an association with plant richness in land snail communities of carbonate cliffs in Wisconsin, USA.

Competition theory predicts that, at equilibrium, the number of coexisting species cannot exceed the number of limiting resources (Hardin, 1960; Phillips, 1973; Armstrong and McGehee, 1980; Grover, 1997). For land snails, only a few resources are potentially limiting, namely (i) feeding sites, at which must be available food materials of the nature that can be 'handled' by the buccal apparatus, ingested and assimilated; (ii) nutrients, although the exact requirements in land snails are poorly understood; and (iii) daytime roosting sites. However, as demonstrated earlier, in New Zealand land snail communities numerous species often coexist. Huisman and Weissing (1999) showed that resource competition models can generate oscillations and chaos when species compete for three or more resources. Further, they showed that these oscillations and chaotic fluctuations in species abundances allow the coexistence of many species on a limited range of resources, consistent with the idea that non-equilibrium conditions may favour species coexistence (Levins, 1979; Armstrong and McGehee, 1980; Sommer, 1985).

New Zealand land snails exhibit the classic species-area relationship in their intra-archipelago patterns of species richness. Evidently the progenitors of the land snail fauna were primarily Gondwanan taxa resident in New Zealand at the time of late Cretaceous separation from Gondwana, and have been supplemented only by rare dispersals from other regions since the end of the Cretaceous. Thus the species-area relationships have risen by intra-archipelago sorting through the classical island biogeographic processes of immigration and extinction (as they relate to combined effects of isolation and area), coupled with spectacular intra-archipelago radiation. Given that speciation has been punctuated, with the last peak probably in the Pliocene, and the frequent 'resetting' effects of macro-scale disturbances, it is not at all certain that an equilibrium condition in the species-area relationship has been reached. Indeed, under these conditions of insularity and in situ phylogenesis, Solem (1990) emphasised that equilibrium is not to be expected in island systems.

The conclusion is therefore that New Zealand land snails are not at equilibrium with the contemporary environment. Spatial heterogeneity in the landscape, at least in part related to pattern of floristic diversity, coupled with as yet incomplete saturation of suitable niches, evidently contribute to the observed present patterns of highly varied site occupancy and thus turnover in species richness. Highest per plot richness in bioregions of low endemism, supports Solem's (1984) idea of accumulation of species through dispersal, and extraordinary richness being achieved where regional conditions favour persistence of a diversity of forest habitat over several million years. Niche conditions may be of such dynamism as to invoke the Huisman and Weissing (1999) model, whereby non-equilibrium promotes coexistence at both regional and local scales.

The landmasses that make up island archipelagoes such as New Zealand are intrinsically unstable because the geological processes that cause their formation are dynamic. Substantial environmental changes can occur on a time-scale comparable to the processes of colonisation, phylogenesis, and extinction (Heaney, 2000). From the late Cretaceous the resident New Zealand fauna has been subjected to repeating cycles of disturbance, followed by recovery through speciation and dispersal. Solem (1990) recognised that every species goes through a series of phases in its evolutionary history, namely (i) evolution as a local population; (ii) expansion of range, often 
considerable; then either (iii) fragmentation into isolated populations, some of which may give rise to new species; or (iv) contraction in range; and eventually $(\mathrm{v})$ returning to a small population (not necessarily in the same place as where initial speciation occurred), before (vi) extinction. In looking at species ranges, Solem emphasised it is important to determine whether a particular example is at the start or near the end of this "species life span". Clearly, at the assemblage level, the situation can be highly complex as there will often be species at different phases in their evolutionary history cycle. In New Zealand this complexity is especially acute due to the highly dynamic nature of the environment over millions of years.

Five, well-documented, major events have been postulated to have had a dramatic impact on New Zealand biodiversity: the break from Gondwana approximately 80 mya; the submersion, and subsequent recovery, of perhaps as much as $80 \%$ of land area ca. 25 mya; considerable reconfiguration of the geological terranes during the last 30 million years, including at least $480 \mathrm{~km}$ of horizontal displacement on the South Island along the Alpine Fault; the formation of the axial mountain ranges in the last 5 million years; and the climatic deterioration that began in the late Miocene. In the absence of phylogeographic information, it is presently difficult to partition effects among these disturbance events, but all can be expected to still imprint on contemporary land snail communities. The bioregion classification used in this paper endeavoured to encapsulate the intra-archipelago patterns in disturbance histories, and indeed we see strong differences among bioregions in composition, structure and emergent properties of regional faunas and communities.

A large component of the present apparent disequilibrium in New Zealand land snail communities probably relates directly to the Pleistocene. Most areas of New Zealand were profoundly affected by Pleistocene glacial/ interglacial cycles. Only in the northernmost regions where the vegetation evidently was mostly continuous forest/shrubland was habitat readily available. In other areas during glacial periods, forest-scrubland patches acted as paleorefugia sensu Nekola (1999b) as fragmented relicts of a formerly widespread matrix community. Studies involving other taxonomic groups suggest survival in a mosaic of ecological refugia rather than one or few, regional refugia (e.g., Trewick, 2001). Nekola (1999b) postulated that extinction is an important process in determining species occurrences in paleorefugia. Thus, while these remnant forestscrubland patches were important in retention of land snail diversity during the glacial maxima, we would expect substantial losses due to island biogeographic and stochastic processes. During the interglacial and post-glacial periods, forest reestablished over the greater part of the landscape and created new habitat for land snails. Here immigration should be highly important in determining species occurrences, and indeed species with good dispersive powers should dominate communities. As most speciation probably occurred prior to Pleistocene glaciation, the presence of locally-endemic species indicates survival in paleorefugia, while the presence of species ranging across biogeographic provinces within New Zealand indicates dispersal. Thus differences in survival and colonization histories can be expected to influence land snail communities 5,000-10,000 years following habitat development.

New Zealand land snail communities exhibit a strong predominance of minute species with low shell H:D ratios. If shell shapes define the repetoire of available niches then there is something different about New Zealand in respect to niche open to land snails, relative to many other regions in which the faunas typically exhibit a bimodal pattern in the spire index. That the shell morphologies in the New Zealand representatives conform rather closely to that expected within the respective families worldwide, suggests the morphospace pattern seen in the New Zealand fauna is largely a circumstance of history and has little to do with ecology. However, the high levels of cladogenesis suggest innovations in ecological niches, which are not evident to us in examination of the shell $\mathrm{H}: \mathrm{D}$ morphospace.

Radiation in punctoidean land snails in New Zealand has previously been attributed to the absence of competition from other faunal elements such as advanced helicids (Solem, 1959; Climo, 1975). Furthermore, the absence of mammalian predators is a commonly noted factor in discussions on the evolution of the New Zealand biota. Yet, there is actually little quantitative understanding of the evolutionary consequences of the competitor snail or mammalian absences from the archipelago. Daugherty et al. (1993) assert that with the absence of mammals, a set of morphological and life history traits commonly evolved in diverse taxa in response to the low predatory pressure. While this may hold for birds, there is little evidence that the traits of New Zealand land snails are different from those in mammal-rich continental areas. Contrary to Daugherty et al. (1993), the large size, long lifespan and low reproductive rate in Powelliphanta and Paryphanta (Rhytididae) land snails is not unexpected when we look to closely related genera in eastern Australia and South Africa. Studies of organisms from remote islands are unequivocal in their support for the idea that morphological and ecological divergence may be accelerated in competitor-depauperate environments. 
Nonetheless, there is some support for the idea that predation may interact with competition to affect adaptive radiation in island biotas (Gurevitch et al., 2000; Benkman, 1991).

\section{ACKNOWLEDGEMENTS}

This research was partially funded by the Foundation for Research, Science and Technology under contracts C09X0204 and C09X0202. I am grateful to Bruce A. Marshall for access to the land snail collections and associated accessions databases held at Museum of New Zealand Te Papa Tongarewa, Wellington. Many people over nearly two centuries have contributed to this magnificant resource through collecting, curation and databasing. Bruce Marshall, Karin Mahlfeld and Dave J. Roscoe assisted in databasing accessions in the Museum, and Jake McC. Overton, Robert Price and Christel Dischinger (Landcare Research, Hamilton) assisted with establishment of the spatial databases and data analyses. A number of colleagues kindly provided distributional data, especially Fred J. Brook (Whangarei), Kath Walker (Department of Conservation, Nelson), Dave Roscoe, Pauline C. Mayhill (Tauranga) (deceased) and Jim F. Goulstone (Auckland) (deceased). I am grateful to the many private landowners and Department of Conservation for permission to access sites and sample land snail communities. Dr Antonio de Frias Martins (University of the Azores) provided estimates of global species richness in Ellobiidae. Dr Joseph A. Veech (Colorado State University, Fort Collins) provided access to PARTITION software. Greg Arnold (Landcare Research, Palmerston North) assisted with statistical analyses. Preparation of the manuscript greatly benefited from the critical comments of Bruce Marshall, Fred Brook, Jeff C. Nekola, Robert A.D. Cameron, Beata M. Pokryszko, William G. Lee and Daphne E. Lee.

\section{REFERENCES}

Adams, C.J.D. (1979). Age and origin of the Southern Alps. In R.I. Walcott and M.M. Cresswell (eds), The Origin of the Southern Alps. Royal Society of New Zealand, Bulletin No. 18: 73-78. Royal Society of New Zealand, Wellington.

Allen, J.A. (2004). Avian and mammalian predators of terrestrial gastropods. In G.M. Barker (ed.), Natural Enemies of Terrestrial Molluscs: 1-36. CABI Publishing, Wallingford.

Arensburger, P., Simon, C. and Holsinger, K. (2004). Evolution and phylogeny of the New Zealand cicada genus Kikihia Dugdale (Homoptera: Auchenorrhyncha: Cicadidae) with special reference to the Norfolk Islands' species. Journal of Biogeography 31: 1769-1783.
Armstrong, R.A. and McGehee, R. (1980). Competitive exclusion. The American Naturalist 115: 151-170.

Auerbach, M. and Shmida, A. (1987). Spatial scale and the determinants of plant species richness. Trends in Ecology and Evolution 2: 238-242.

Barker, G.M. (2001). Gastropods on land: phylogeny, diversity and adaptive morphology. In G.M. Barker (ed.), The Biology of Terrestrial Molluscs: 1-146. CABI Publishing, Wallingford.

Barker, G.M. (2002). Gastropods as pests in New Zealand pastoral agriculture. In G.M. Barker (ed.), Molluscs as Crop Pests: 361-423. CABI Publishing, Wallingford.

Barker, G.M. and Efford, M.G. (2004). Predatory gastropods as natural enemies of terrestrial gastropods and other invertebrates. In G.M. Barker (ed.), Natural Enemies of Terrestrial Molluscs: 279-403. CABI Publishing, Wallingford.

Barker, G.M., Knutson, L., Vala, J-P., Coupland, J.B. and Barnes, J.K. (2004). Overview of the biology of marsh flies (Diptera: Sciomyzidae), with special reference to predators and parasitoids of terrestrial gastropods. In G.M. Barker (ed.), Natural Enemies of Terrestrial Molluscs: 159-225. CABI Publishing, Wallingford.

Barker, G.M. and Mayhill, P.C. (1996). Terrestrial mollusc communities of the Pukeamaru Ecological District, East Cape, North Island, New Zealand: patterns of diversity, habitat relationships and conservation status. Unpublished Report.

Barker, G.M. and Mayhill, P.C. (1999). Patterns of diversity and habitat relationships in terrestrial mollusc communities of the Pukeamaru Ecological District, northeastern New Zealand. Journal of Biogeography 25: 215-238.

Belbin, L. (1991). Semi-strong hybrid scaling, a new ordination algorithm. Journal of Vegetation Science 2: 491-496.

Belbin, L. (1995). PATN Analysis Package. Division of Sustainable Ecosystems, CSIRO, Canberra.

Benkman, C.W. (1991). Predation, seed-size partitioning and the evolution of body size in seed-eating finches. Evolutionary Ecology 5: 118-127.

Borcard, D., Legendre, P.- and Drapeau, P. (1992). Partialling out the spatial component of ecological variation. Ecology 73: 1045-1055.

Breitwieser, I., Glenny, D.S., Thorne, A. and Wagstaff, S.J. (1999). Phylogenetic relationships in Australasian Gnaphaliaea (Compositae) inferred from ITS sequences. New Zealand Journal of Botany 37: 399-412.

Bray, J.R. and Curtis, J.T. (1957). An ordination of the upland forest communities of southern Wisconsin. Ecological Monographs 27: 325-349.

Bray, R.J. and Gorham, E. (1964). Litter production in forests of the world. In J.B. Cragg, (ed.), Advances in Ecological Research, 2: 101-157. Academic Press, London and New York.

Briggs, J.C. (2003). Fishes and birds: Gondwana life rafts reconsidered. Systematic Biology 52: 548-553.

Brook, F.J. (1999a). Biogeography and ecology of the landsnail faunas of North East, South West and West Islands, Three Kings Group, northern New Zealand. Journal of the Royal Society of New Zealand 29: 1-21.

Brook, F.J. (1999b). Changes in the landsnail fauna of 
Lady Alice Island, northeastern New Zealand. Journal of the Royal Society of New Zealand 29: 135-157.

Brook, F.J. (1999c). Stratigraphy and landsnails faunas of Late Holocene coastal dunes, Tauroa Beach, northern New Zealand. Journal of the Royal Society of New Zealand 29: 377-359.

Brook, F.J. (1999d). Stratigraphy, landsnails faunas, and paleoenvironmental history of coastal dunefields at Te Werahi, northernmost New Zealand. Journal of the Royal Society of New Zealand 29: 361-393.

Brook, F.J. (1999e). Stratigraphy, landsnails faunas, and paleoenvironmental history of Late Holocene coastal dunes, Tauroa Peninsula, northern New Zealand. Journal of the Royal Society of New Zealand 29: 395-405.

Brook, F.J. (2002). Changes in the landsnail fauna of Great Island, Three Kings Islands, northern New Zealand. Journal of the Royal Society of New Zealand 32: 61-88.

Brook, F.J. and Goulstone, J.F. (1999). Prehistoric and present-day coastal landsnail faunas between Whananaki and Whangamumu, northeastern New Zealand, and implications for vegetation history following human colonisation. Journal of the Royal Society of New Zealand 29: 107-134.

Brook, F.J. and McArdle, B.H. (1999). Morphological variation, biogeography and local extinction of the northern New Zealand landsnail Placostylus hongii (Gastropoda: Bulimulidae). Journal of the Royal Society of New Zealand 29: 407-434.

Broomfield, C.H. (1983). Native Land Snail Survey, Jubilee Park, Hamilton 1982-1983. Unpublished Report.

Brownsey, P.J. (2001). New Zealand's pteridophyte flora - plants of ancient lineage but recent arrival? Brittonia 53: 284-303.

Buckley, T.R., Simon, C., Shimodaira, H. and Chambers, G.K. (2001). Evaluating hypotheses on the origin and evolution of the New Zealand alpine cicadas (Maoricicada) using multiple-comparison tests of tree topology. Molecular Biology and Evolution 18: 223-234.

Bull, P.C. and Whittaker, A.H. (1975). The amphibians, reptiles, birds and mammals. In G. Kuschel (ed.), Biogeography and Ecology in New Zealand: 231-276. Dr W. Junk Publishers, The Hague.

Cain, A.J. (1977). Variation in the spire index of some coiled gastropod shells, and its evolutionary significance. Philosophical Transactions of the Royal Society of London, Biological Sciences 277: 377-428.

Cain, A.J. (1978). The deployment of operculate land snails in relation to shape and size of shell. Malacologia 17: 207-221.

Cain, A.J. (1980). Whorl number, shape, and size of shell in some pulmonate faunas. Journal of Conchology 30: 209-221.

Cain, A.J. (1983). Ecology and ecogenetics of terrestrial populations. In W.D. Russell-Hunter (ed.), The Mollusca, Volume 6. Ecology: 597-647. Academic Press, London.

Cain, A.J. and Cowie, R.H. (1978). Activity of different species of land snail on surfaces of different inclinations. Journal of Conchology 29: 267-272.

Caley, M.J. and Schluter, D. (1997). The relationship between local and regional diversity. Ecology 78: 7080.
Cameron, R.A.D. (1988). Incomplete convergence of shell sizes and shapes in forest snail faunas from two continents: a relic of environmental history? Malacologia 28: 147-157.

Cameron, R.A.D. (1992). Land snail faunas of the Napier and Oscar Ranges, Western Australia; diversity, distribution and speciation. Biological Journal of the Linnean Society 45: 271-286.

Cameron, R.A.D. (1995). Patterns of diversity in land snails: the effects of environmental history. In A.C. van Bruggen and S.M. Wells (eds), Biodiversity and Conservation of the Mollusca: 187-204. Backhuys Publishers, Oegstgeest-Leiden.

Cameron, R.A.D. and Cook, L.M. (1989). Shell size and shape in Madeiran land snails: do niches remain unfilled? Biological Journal of the Linnean Society 36: 7996.

Cameron, R.A.D. and Pokryszko, B.M. (2004). Land mollusc faunas of Białowieża forest (Poland), and the character and survival of forest faunas in the north European plain. Journal of Molluscan Studies 70: 149164.

Caswell, H. and Cohen, J.E. (1993). Local and regional regulation of species-area relations: a patch occupancy model. In R.E. Ricklefs and D. Schluter (eds), Species Diversity in Ecological Communities: Historical and Geographical Perspectives: 99-107. University of Chicago Press, Chicago.

Chambers, G.K., Boon, W.M., Buckley, T.R. and Hitchmough, R.A. (2001). Using molecular methods to understand the Gondwanan affinities of the New Zealand biota: three case studies. Australian Journal of Botany 49: 377-387.

Chiba, S. (2002). Ecological diversity and speciation in land snails of the genus Mandarina from the Bonin Islands. Population Ecology 44: 179-187.

Clarkson, B.D., Clarkson, B.R. and McGlone, M.S. (1986). Vegetation history of some west Taupo mires. In B. Veale and J. Innes (eds), Ecological Research in the Central North Island: 34-37. Forest Research Institute, Rotorua.

Climo, F.M. (1971). Systematic position: Cytora, Liarea. Transactions of the Royal Society of New Zealand, Biological Sciences 12: 209-212.

Climo, F.M. (1973). The systematics, biology and zoogeography of the land snail fauna of Great Island, Three Kings Group, New Zealand. Journal of the Royal Society of New Zealand 3: 565-628.

Climo, F.M. (1975). The land snail fauna. In G. Kuschel (ed.), Biogeography and Ecology in New Zealand: 459492. Dr W. Junk Publishers, The Hague.

Climo, F.M. (1978). Classification of New Zealand Arionacea (Mollusca: Pulmonata). A review of the New Zealand charopine snails with lamellate apertures. National Museum of New Zealand Records 1: 177-201.

Climo, F.M. and Goulstone, J.F. (1993). Description and redescription of landsnails (Mollusca: Punctidae) in the genera Phrixgnathus and Taguahelix. Records of the Auckland Institute and Museum 30: 27-45.

Climo, F.M., Roscoe, D.J. and Walker, K.J. (1986). Research on Land Snails of New Zealand. Research Review No. 9: 1-28. Wildlife Research Liaison Group, Wellington. 
Cook, A. (2001). Behavioural ecology: on doing the right thing, in the right place at the right time. In G.M. Barker (ed.), The Biology of Terrestrial Molluscs: 447487. CABI Publishing, Wallingford.

Cook, A.H. (1895). Molluscs. Cambridge Natural History, 3.

Cooke, C.M. and Kondo, Y. (1960). Revision of Tornatellinidae and Achatinellidae. Bernice P. Bishop Museum Bulletin 221: 1-303. Bernice P. Bishop Museum, Honolulu.

Cooper, A. and Cooper, R.A. (1995). The Oligocene bottleneck and the New Zealand biota: genetic record of a past environmental crisis. Proceedings of the Royal Society of London, Series B. 261: 293-302.

Cooper, A., Lalueza-Fox, C., Anderson, S., Rambaut, A., Austin, J. and Ward, R. (2001). Complete mitochondrial genome sequences of two extinct moas clarify ratite evolution. Nature 409: 704-707.

Cooper, R.A. (1989). New Zealand tectonostratigraphic terranes and panbiogeography. New Zealand Journal of Zoology 16: 699-712.

Cooper, R.A. (1998). The Oligocene 'bottleneck' hypothesis - physical parameters. In R.A. Cooper, R.A. and C.M. Jones (eds), Geology and Genes: 19-22. Extended Abstracts of papers presented at the Geogenes 98 Conference, Science House, Wellington 24 March 1998. Geological Society of New Zealand Miscellaneous Publication No. 97. Geological Society of New Zealand, Wellington.

Cooper, R.A. and Millener, P.R. (1993). The New Zealand biota: historical background and new research. Trends in Ecology and Evolution 8: 429-433.

Cornell, H.V. (1985). Local and regional richness of cynipine gall wasps on California oaks. Ecology 66: 1247-1260.

Cornell, H.V. (1993). Unsaturated patterns in species assemblages: the role of regional processes in setting local species richness. In R.E. Ricklefs and D. Schluter (eds), Species Diversity in Ecological Communities. Historical and Geographical Perspectives: 243-252. University of Chicago Press, Chicago.

Cornell, H.V. and Lawton, J.H. (1992). Species interactions, local and regional processes, and limits to the richness of ecological communities: a theoretical perspective. Journal of Animal Ecology 61: 1-12.

Coupland, J.B. and Barker, G.M. (2004). Diptera as predators and parasitoids of terrestrial gastropods, with emphasis on Phoridae, Calliphoridae, Sarcophagidae, Muscidae and Fanniidae. In G.M. Barker (ed.), Natural Enemies of Terrestrial Molluscs: 85158. CABI Publishing, Wallingford.

Cowie, R.H. (1995). Variation in species diversity and shell shape in Hawaiian land snails: in situ speciation and ecological relationships. Evolution 49: 1191-1202.

Cowie, R.H. (1996). Pacific island land snails: relationships, origins, and determinants of diversity. In A. Keast and S.E. Miller (eds), The Origin and Evolution of Pacific Island Biotas, New Guinea to Eastern Polynesia: Patterns and Processes. SPB Academic Publishing, Amsterdam, pp. 347-72.

Crist, T.O., Veech, J.A., Gering, J.C. and Summerville,
K.S. (2002). Partitioning species diversity across landscapes and regions: a hierarchial analysis of $\alpha, \beta$ and $\gamma$ diversity. The American Naturalist 162: 734-743.

Cumber, R.A. (1962). Paleogeographic history reflected in speciation trends of the New Zealand ribbed pulmonate Charopa coma (Gray) (Charopidae). Transactions of the Royal Society of New Zealand, Zoology 1: 365-371.

Czekanowski, J. (1913). Zarys Metod Statystycznych. Czekanowski, Warsaw.

Dawson, J.W. (1986). The vines, epiphytes and parasites of New Zealand forests. Tuatara 28: 43-69.

Dawson, J.W. and Sneddon, B.V. (1969). The New Zealand rain forest: a comparison with tropical rain forest. Pacific Science 23: 131-147.

Daugherty, C.H., Gibbs, G.W. and Hitchmough, R.A. (1993). Mega-island or micro-continent? New Zealand and its fauna. Trends in Ecology and Evolution 8: 437-442.

Druce, A.P. (1993). Indigenous Higher Plants of New Zealand. Landcare Research, Lower Hutt. Unpublished Report.

Efford, M.G. (1998). Distribution and Status of Native Carnivorous Land Snails in the Genera Wainuia and Rhytida. Science for Conservation No. 101: 1-48. Department of Conservation, Wellington.

Emberton, K.C. (1988). The genitalic, allozymic, and conchological evolution of the eastern North American Triodopsinae (Gastropoda: Pulmonata: Polygyridae). Malacologia 28: 159-273.

Emberton, K.C. (1991). Ecology of a shell convergence between subfamilies of polygyrid land snails. Biological Journal of the Linnean Society 44: 105-120.

Emberton, K.C. (1994). Partitioning a morphology among its controlling factors. Biological Journal of the Linnean Society 53: 353-369.

Emberton, K.C. (1995). Land-snail community morphologies of the highest-diversity sites of Madagascar, North America, and New Zealand, with recommended alternatives to height-diameter plots. Malacologia 36: 43-66.

Faith, D.P., Minchin, P.R. and Belbin, L. (1987). Compositional dissimilarity as a robust measure of ecological distance. Vegetatio 69: 57-68.

Fischer, P.H. (1880-1887). Manuel de Conchyliologique et de Paléontologie Conchyliologique ou Histoire Naturelle des Mollusques Vivants et Fossiles, suivi d'un appendice sue les Brachiopodes par D.P. CEhlert. Librairie F. Savy, Paris.

Froggatt, P.C. and Lowe, D.J. (1990). A review of late Quaternary silicic and some other tephra formations from New Zealand: their stratigraphy, nomenclature, distribution, volume, and age. New Zealand Journal of Geology and Geophysics 33: 89-109.

Gardner, N. (1977). Collecting land snails in the Lake Haurako area of southern Fiordland, New Zealand. Poirieria 9: 35-41

Gardner, N. and Goulstone, J.F. (1977). A Report on the Native Land Snails of the Lake Hauroko Area of Southern Fiordland. Unpublished Report.

Gering, J.C. and Crist, T.O. (2002). The alpha-betaregional relationship: providing new insights into local-regional patterns of species richness and scale 
dependence of diversity components. Ecology Letters 5: 433-444.

Gering, J.C., Crist, T.O. and Veech, J.A. (2003). Additive partitioning of species diversity across multiple spatial scales: implications for regional conservation of biodiversity. Conservation Biology 17: 488-499.

Getz, L.L. and Uetz, G.W. (1994). Species diversity of terrestrial snails in the southern Appalachian mountains, USA. Malacological Review 27: 61-74.

Gleeson, D.M. (1996). Onychophora of New Zealand; past, present and future. The New Zealand Entomologist 19: 51-55.

Goulstone, J.F. (1976). Some Land Snails from Lake Waikaremoana-May 1976. Unpublished Report.

Goulstone, J.F. (1977a). Native Land Snails from the Hunua Range and Several Locations in South Auckland. Unpublished Report.

Goulstone, J.F. (1977b). Further Land Snails from the Ureweras and Eastern Bay of Plenty. Unpublished Report.

Goulstone, J.F. (1978). Land Snails from Lake Waikaremoana - May 1978. Unpublished Report.

Goulstone, I.F. (1979a). Land Snails from the Whakatane River. Unpublished Report.

Goulstone, J.F. (1979b). Land Snails from the Coromandel Peninsula and Some Adjacent Areas. Unpublished Report.

Goulstone, J.F. (1980a). Land Snails from Mason Bay, Stewart Island, 1980. Unpublished Report.

Goulstone, J.F. (1980b). Landsnails from Waikareomoana May 1980. Unpublished Report.

Goulstone, J.F. (1980c). Native Landsnails in the Moehau Block, Coromandel Peninsula - May 1980. Unpublished Report.

Goulstone, J.F. (1981a). Land Snails from Great Barrier Island - January 1981. Unpublished Report.

Goulstone, J.F. (1981b). Land Snails from the Waiau River and Waikaremoana-May 1981. Unpublished Report.

Goulstone, J.F. (1982). Pureora Land Snails. Unpublished Report.

Goulstone, J.F. (1983). Some Snails from Around Hokitika. Unpublisherd Report.

Goulstone, J.F. (1984a). Landsnails from the Catlins, SouthEast Otago - 1984. Unpublished Report.

Goulstone, J.F. (1984b). Landsnails from Waikareomoana November 1984. Unpublished Report.

Goulstone, J.F. (1986). Rangitoto Island Land Snail Survey (1976 - 1977). Unpublished Report.

Goulstone, J.F. (1990). Land snails from South Auckland. Poirieria 16: 1-44.

Goulstone, J.F. (1991). Landsnails from Dunedin and its Environs - January 1991. Unpublished Report.

Goulstone, J.F. (1995). Five new species of Climocella n. gen. (Punctoidea: Charopidae). Records of the Auckland Institute and Museum 32: 63-90.

Goulstone, J.F. (1996). Seven new species of Climocella (Gastropoda: Punctoidea: Charopidae) from northern New Zealand. Records of the Auckland Institute and Museum 33: 173-194.

Goulstone, J.F. (2001). A revision of the genus
Phenacohelix Suter, 1892 (Mollusca: Pulmonata) with description of four new species and reassessment of Thalassohelix ziczag (Gould, 1846). Records of the Auckland Institute and Museum 38: 39-82.

Goulstone, J.F. and Brook, F.J. (1999). Description of five species of terrestrial molluscs (Gastropoda: Stylommatophora: Punctidae, Charopidae, Rhytididae) discovered in the Three Kings Islands, northern New Zealand. Joumal of the Royal Sciety of New Zealand 29: 23-39.

Goulstone, J.F. and Mayhill, P.C. (1998). Three new species of Climocella (Gastropoda: Punctoidea: Charopidae) from northern New Zealand, and transfer/assignment of Charopa (Mocella) accelerata Climo, 1970 to the genus Flammocharopa Climo, 1970. New Zealand Journal of Zoology 25: 273-285.

Goulstone, J.F., Mayhill, P.C. and Parrish, G.R. (1993). An illustrated guide to the land Mollusca of the Te Paki Ecological Region, Northland, New Zealand. Tane 34: $1-32$.

Gower, J.C. (1971). A general coefficient of similarity and some of its properties. Biometrics 27: 857-871.

Grover, J.P. (1997). Resource Competition. Chapman and Hall, London.

Gurevitch, J., Morrison, J.A. and Hedges, L.V. (2000). The interaction between competition and predation: metaanalysis of field experiments. The American Naturalist 155: 435-453.

Hardin, G. (1960). The compeition exclusion principle. Science 131: 1292-1298.

Hayward, B.W. and Brook, F.J. (1981). Exploitation and redistribution of flax snail (Placostylus) by the prehistoric Maori. New Zealand Journal of Ecology 4: 33-36.

Heaney, L.R. (2000). Dynamic disequilibrium: a longterm, large-scale perspective on the equilibrium model of island biogeography. Global Ecology and Biogeography 9: 59-74.

Hedges, S.B., Parker, P.H., Sibley, C.G. and Kumar, S. (1996). Continental breakup and the ordinal diversification of birds and mammals. Nature 381: 226-229.

Heller, J. (1987). Shell shape and land-snail habitat in a Mediterranean and desert fauna. Biological Journal of the Linnean Society 31: 257-272.

Hickson, R.E., Slack, K.E. and Lockhart, P.J. (2000). Phylogeny recapitulates geography, or why New Zealand has so many species of skinks. Biological Journal of the Linnean Society 70: 415-433.

Hoot, S.B. and Douglas, A.W. (1998). Phylogeny of the Proteaceae based on atpB and atp B-rbcL intergenetic spacer region sequences. Australian Systematic Botany 11: $320-339$.

Hubbell, S.P. (2001). The Unified Neutral Theory of Biodiversity and Biogeography. Princeton University Press, Princeton.

Huisman, J. and Weissing, F.J. (1999). Biodiversity of plankton by species oscillations and chaos. Nature 402: $407-410$.

Iredale, T. (1913). The land Mollusca of the Kermadec Islands. Proceedings of the Malacological Society of London 10: 364-388, pl. 1. 
Iredale, T. (1915). A comparison of the land molluscan faunas of the Kermadec Group and Norfolk Island. Transactions and Proceedings of the New Zealand Institute 47: 498-507.

Kabat, A.R. and Hershler, R. (1993). The Prosobranch Snail Family Hydrobiidae (Gastropoda: Rissooidea): Review of Classification and Supraspecific Taxa. Smithsonian Contributions to Zoology No. 547: 1-94. Smithsonian Institute Press, Washington D.C.

Kear, D. (1993). Reflections on major North Island basement rock assemblages and on megafaults. Journal of the Royal Society of New Zealand 23: 29-41.

King, P.R. (1998). Paleogeographic reconstructions of New Zealand. In R.A. Cooper and C.M. Jones (eds), Geology and Genes: 45-48. Extended Abstracts of papers presented at the Geogenes 98 Conference, Science House, Wellington 24 March 1998. Geological Society of New Zealand Miscellaneous Publication No. 97. Geological Society of New Zealand, Wellington.

King, P.R. (2000). Tectonic reconstructions of New Zealand: $40 \mathrm{Ma}$ to the Present. New Zealand Journal of Geology and Geophysics 43: 611-638.

Kondo, Y. (1962). The Genus Tubuaia Pulmonata, Achatinellidae. Bernice P. Bishop Museum Bulletin 224: 1-49. Bernice P. Bishop Museum, Honolulu.

Korsch, R.J. and Wellman, H.W. (1988). The geological evolution of New Zealand and the New Zealand region. In A.E.M. Nairn, F.G. Stehli and S. Uyeda (eds), The Ocean Basins and Margins. Volume 7B, The Pacific Ocean: 411-482. Plenum Press, New York.

Ladd, H.S. (1960). Origin of the Pacific Island molluscan fauna. American Journal of Science, Bradley Volume 258A: 137-150.

Lande, R. (1996). Statistics and partitioning of species diversity, and similarity among multiple communities. Oikos 76: 5-13.

Laporta-Ferreira, I.L. and Salomão, M.G. (2004). Reptilian predators of terrestrial gastropods. In G.M. Barker (ed.), Natural Enemies of Terrestrial Molluscs: 427-481. CABI Publishing, Wallingford.

Leathwick, J.R. (2001). New Zealand's potential forest pattern as predicted from current speciesenvironment relationships. New Zealand Journal of Botany 39: 447-464.

Leathwick, J.R., Morgan, F.J., Wilson, G.H., Rutledge, D., McLeod, M., Johnston, K. (2002a). Land Environments of New Zealand: A Technical Guide: 1-237. Ministry for the Environment, Wellington.

Leathwick, J.R., Overton, J.McC. and McLeod, M. (2002b). An environmental domain classification of $\mathrm{New}$ Zealand and its use as a tool for biodiversity management. Conservation Biology 17: 1612-1623.

Leathwick, J.R. and Stephens, R.T.T. (1998). Climate Surfaces for New Zealand. Landcare Research Contract Report LC9798/126: 1-19. Landcare Research, Hamilton.

Leathwick, J.R., Wilson, G.H., Rutledge, D., Wardle, P., Morgan, F.J., Johnston, K., McLeod, M. and Kirkpatrick, R. (2003). Land Environments of New Zealand: Nga Taiao o Aotearoa. Batemans, Auckland.

Lee, W.G. (1998). The vegetation of New Zealand functional, spatial, and temporal gaps. In R. Lynch (ed.), Ecosystems, Entomology \& Plants: 91-101. Proceedings of a symposium held at Lincoln University to mark the retirement of Bryony Macmillan, John Dugdale, Peter Wardle and Brian Molloy, 1 September 1995. Royal Socety of New Zealand, Wellington.

Lee, D.E., Lee, W.G. and Mortimer, N. (2001). Where and why have all the flowers gone? Depletion and turnover in the New Zealand Cenozoic angiosperm flora in relation to palaeography and climate. Australian Journal of Botany 49: 341-356.

Legendre, P. (1990). Quantitative methods and biogeographic analysis. In D.J. Garbary and G.R. South (eds), Evolutionary Biogeography of the Marine Algae of the North Atlantic: 9-34. NATO ASI Series, Volume G 22. Springer, Berlin.

Legendre, L. and Legendre, P. (1998). Interpretation of ecological structures. In Numerical Ecology. $2^{\text {nd }}$ Edition: 481-574. Elsevier, Amsterdam.

Levins, R. (1979). Coexistence in a variable environment. The American Naturalist 114: 765-783.

Lewis, K.B., Carter, L. and Davey, F.J. (1994). The opening of Cook Strait: interglacial tidal scour and aligning basins at a subduction to transform plate edge. Marine Geology 116: 293-312.

Macphail, M.K. (1997). Comment on M. Pole (1994): The New Zealand flora - entirely long-distance dispersal? $\mathrm{J}$. Biogeography 21, 625-635. Journal of Biogeography 24: 113-114.

Mahlfeld, K. (1990). Landsnail Communities on Awhitu Peninsula and Their Habitats. Unpublished MSc Thesis: 1-81. Westfälische Wilhelms Universität, Münster.

Mahlfeld, K. (2000). Impact of introduced gastropods on molluscan communities, northern North Island. Conservation Advisory Science Notes No. 277: 1-60. Department of Conservation, Wellington.

Manos P.S. (1997). Systematics of Nothofagus (Nothofagaceae) based on rDNA spacer sequences (ITS): taxonomic congruence with morphology and plastid sequences. American Journal of Botany 84: 11371155.

Markgraf, V., McGlone, M. and Hope, G. (1995). Neogene paleoenvironmental and plaleoclimatic change in southern temperate ecosystems - a southern perspective. Trends in Ecology and Evolution 10: 143147.

Martins, A.M.F. (1992). Pedipedinae (Gastropoda: Ellobiidae) from Hong Kong. In $\mathrm{B}$. Morton (ed.), The Marine Flora and Fauna of Hong Kong and Southern China III: $693-704$. Proceedings of the Fourth International Marine Biological Workshop: The Marine Flora and Fauna of Hong Honk and Southern China, 11-29 April 1989. Hong Kong University Press, Hong Kong.

Martins, A.M.F. (2001). Ellobiidae - lost between land and sea. Journal of Shellfish Research 20: 441-446.

Mason, G.M. (1988). Ecological studies of a marine terrace sequence in the Waitutu Ecological District of southern New Zealand. Part 5: Land snails. Journal of the Royal Society of New Zealand 18: 89-90.

Mayhill, P.C. (1981). Landsnails of Tongariro National Park. Poirieria 16: 29-79. 
Mayhill, P.C. (1985). Landsnails of Fiordland National Park. Unpublished Report.

Mayhill, P.C. and Broomfield, C.H. (1982). Landsnail Population Survey, Maungakawa 1981-1982. Unpublished Report.

Mayhill, P.C. and Goulstone, J.F. (1984). Landsnails of the Auckland Islands. Unpublished Report.

Mayhill, P.C. and Goulstone, J.F. (1986). Landsnails of the Auckland Islands. In A. Penniket and G. Breese (eds), Preliminary Report - Expeditions to Auckland Islands Nature Reserve 1973-1984: 86-99. Department of Lands and Survey, Wellington.

McGlone, M.S. (1985). Plant biogeography and the late Cenozoic history of New Zealand. New Zealand Journal of Botany 23: 723-749.

McGlone, M.S. (1997). The response of New Zealand forest diversity to Quaternary climates. In B. Huntley, A.V. Cramer, A.V. Morgan, H.C. Prentice and J.R.M. Allen (eds), Past and Future Rapid Environmental Changes: The Spatial and Evolutionary Responses of Terrestrial Biota: 73-80. NATO ASI Series, 1. Global Environmental Change, Volume 47. Springer, Berlin.

McGlone, M.S. (2004). Winter leaf loss in the New Zealand woody flora. New Zealand Journal of Botany 42: 1-19.

McGlone, M.S., Duncan, R.P. and Heenan, P.B. (2001). Endemism, species selection and the origin and distribution of the vascular plant flora of New Zealand. Journal of Biogeography 28: 199-216.

McGlone, M.S., Salinger, M.J. and Moar, N.T. (1993). Paleovegetation studies of New Zealand's climate since the Last Glacial Maxima. In H.E. Wright, J.E. Kutzbach, T. Webb, W.F. Ruddiman, F.A. StreetPerrott and P.J. Bartlein (eds), Global Climates Since the Last Glacial Maximum: 294-317. University of Minnesota Press, Minneapolis.

McQuillan, P.B. (1993). Nothofagus (Fagaceae) and its invertebrate fauna - an overview and preliminary synthesis. Biological Journal of the Linnean Society 49: 317-354.

Meads, M.J., Walker, K.J. and Elliott, G.P. (1984). Status, conservation, and management of the land snails of the genus Powelliphanta (Mollusca: Pulmonata). New Zealand Journal of Zoology 11: 277-306.

Mildenhall, D.C. (1980). New Zealand late Cretaceous and Cenozoic plant biogeography: a contribution. Palaeogeography, Palaeoclimatology and Palaeoecology 31: 197-233.

Moeed, A. and Meads, M.J. (1983). Invertebrate fauna of four tree species in Orongorongo Valley, New Zealand, as revealed by trunk traps. New Zealand Journal of Ecology 6: 39-53.

Moeed, A. and Meads, M.J. (1985). Seasonality of pitfall trapped invertebrates in three types of native forest, Orongorongo Valley, New Zealand. New Zealand Journal of Zoology 12: 17-53.

Mortimer, N., Tulloch, A.J., Spark, R.N., Walker, N.W., Ladley, E., Allibone, A. and Kimbrough, D.L. (1999). Overview of the Median Batholith, New Zealand: a new interpretation of the geology of the Median Tectonic Zone and adjacent rocks. Journal of African Earth Sciences 29: 257-268.
Myers, N., Mittermeier, R.A., Mittermeier, C.G., da Fonseca, G.A.B. and Kent, J. (2000). Biodiversity hotspots for conservation priorities. Nature 403: 853858.

Nekola, J.C. (1999a). Terrestrial gastropod richness of carbonate cliff and associated habitats in the Great Lakes region of North America. Malacologia 41: 231252.

Nekola, J.C. (1999b). Paleorefugia and neorefugia: the influence of colonization history on community pattern and process. Ecology 80: 2459-2473.

Nekola, J.C. (2003). Large-scale tèrrestrial gastropod community composition patterns in the Great Lakes region of North America. Diversity and Distributions 9: 55-71.

Nekola, J.C. and Smith, T. (1999). Terrestrial gastropod richness patterns in Wisconsin carbonate cliff communities. Malacologia 41: 253-269.

Newnham, R.M., Lowe, D.J. and Williams, P.W. (1999). Quaternary environmental change in New Zealand: a review. Progress in Physical Geography 23: 567-610.

Ogden, J. (1985). An introduction to plant demography with special reference to New Zealand trees. New Zealand Journal of Botany 23: 751-772.

Ogden, J. (1989). On the coenospecies concept and tree migrations during the oscillations of the Pleistocene. Journal of the Royal Society of New Zealand 19: 249-262.

Ogden, J., Fordham, R.A., Pilkington, S. and Serra, R.G. (1991). Forest gap formation and closure along an altitudinal gradient in Tongariro National Park, New Zealand. Journal of Vegetation Science 2: 165-172.

Ogden, J., Wilson, A., Hendy, C. and Newnham, R.M. (1992). The late Quaternary history of kauri (Agathis australis) in New Zealand and its climatic significance. Journal of Biogeography 19: 611-622.

Oliver, W.R.B. (1915). The Mollusca of the Kermadec Islands. Transactions and Proceedings of the New Zealand Institute 47: 509-568, pls. 9-12.

Oliver, W.R.B. (1930). New Zealand epiphytes. Journal of Ecology 18: 1-50.

Phillips, O.M. (1973). The equilibrium and stability of simple marine biological systems. I. Primary nutrient consumers. The American Naturalist 107: 73-93.

Pickard, A.L., Adams, C.J. and Barley, M.E. (2000). Australian provenance for Upper Permian to Cretaceous rock forming accretionary complexes on the New Zealand sector of the Gondwanaland margin. Australian Journal of Earth Sciences 47: 9871007.

Pilsbry, H.A. (1900). The genesis of mid-Pacific faunas. Proceedings of the Academy of Natural Sciences of Philadelphia 3: 568-581.

Pole, M. (1993). Keeping in touch: vegetation prehistory on both sides of the Tasman. Australian Systematic Botany 6: 387-397.

Pole, M. (1994). The New Zealand flora - entirely longdistance dispersal? Journal of Biogeography 21: 625-635.

Ponder, W.F. (1988). The truncatelloidean (= rissoacean) radiation - a preliminary phylogeny. In W.F. Ponder (ed.), Prosobranch Phylogeny: 129-166. Malacological Review, Supplement 4.

Ponder, W.F., Colgan, D.J., Clark, G.A., Miller, A.C. and 
Terzis, T. (1994). Microgeographic genetic and morphological differentiation of freshwater snails the Hydrobiidae of Wilsons Promontory, Victoria, south-eastern Australia. Australian Journal of Zoology 42: 557-678.

Ponder, W.F., Colgan, D.J., Gleeson, D.M. and Sherley, G.H. (2003). Relationships of Placostylus from Lord Howe Island: an investigation using the mitochondrial cytochrome $c$ oxidase 1 gene. Molluscan Research 23: 159-178.

Ponder, W.F., Eggler, P. and Colgan, D.J. (1995). Genetic differentiation of aquatic snails (Gastropoda: Hydrobiidae) from artesian springs in arid Australia. Biological Journal of the Linnean Society 56: 553-596.

Ponder, W.F. and Warén, A. (1988). Classification of the Caenogastropoda and Heterostropha - a list of the family-group names and higher taxa. Malacological Review 4: 288-326.

Powell, A.W.B. (1979). New Zealand Mollusca. Marine, Land and Freshwater Shells. Collins, Auckland.

Ripley, B.D. (1976). The second-order analysis of stationary processes. Journal of Applied Probability 13: 255-266.

Ripley, B.D. (1981). Spatial Statistics. John Wiley and Sons, New York

Robbins, R.G. (1962). The podocarp-broadleaf forests of New Zealand. Transactions of the Royal Society of New Zealand, Botany 1: 33-75.

Rogers, G.M. and McGlone, M.S. (1989). A vegetation history of the southern-central uplands of the North Island. Journal of the Royal Society of New Zealand 19: 229-248.

Roscoe, D.J. (1989). Panbiogeography and the public. New Zealand Journal of Zoology 16: 757-762.

Roscoe, D.J. (1992). Breaksea discoveries. Poirieria 16: 616.

Rosenzweig, M.L. (1995). Species Diversity in Space and Time. Cambridge University Press, Cambridge.

Roth, B. (1991). Tropical 'physiognomy" of a land-fauna faunule from the Ecocene of Southern California. Malacologia 33: 281-288.

Russell, R.S. (1936). Mechanism of leaf-fall in certain New Zealand trees. Transactions of the Royal Society of New Zealand 65: 407-421.

Rutledge, D.T. and Wilson, G.W. (2003). Climate Parameters for New Zealand's Offshore Islands. Landcare Research Contract Report LC0203/076: 1-22. Landcare Research, Hamilton.

Shaw, W.B. (1983). Tropical cyclones: determinants of pattern and structure in New Zealand's indigenous forests. Pacific Science 37: 405-414.

Schileyko, A.A. (1998). Treatise on Recent Terrestrial Pulmonate Molluscs. Part 2. Gastrocoptidae, Hypselostomatidae, Vertiginidae, Truncatellinidae, Pachnodidae, Enidae, Sagdidae. Ruthenica, Supplement 2: 128-261.

Schileyko, A.A. (2001). Treatise on Recent Terrestrial Pulmonate Molluscs. Part 7. Endodontidae, Thyrophorellidae, Charopidae. Ruthenica, Supplement 2: 881-1034.

Schileyko, A.A. (2002a). Treatise on Recent Terrestrial Pulmonate Molluscs. Part 8. Punctidae, Helicodiscidae,
Discidae, Cystopeltidae, Euconulidae, Trochomorphidae. Ruthenica, Supplement 2: 1034-1166.

Schileyko, A.A. (2002b). Treatise on Recent Terrestrial Pulmonate Molluscs. Part 9. Helicarionidae, Gymnarionidae, Rhysotinidae, Ariophantidae. Ruthenica, Supplement 2: 1167-1307.

Schmid, G. (1966). Die Mollusken des Spitzbergs. Natur und Landschaftsschutzgebiete Baden Württemberg 3: 596701.

Simberloff, D. (1995). Why do introduced species appear to devastate islands more than mainland areas? Pacific Science 49: 87-97.

Smale, D. (1991). Provenance changes and movement on the Alpine Fault indicated by heavy minerals from Cretaceous-Cenozoic sediments in south Westland. Journal of the Royal Society Zealand 21: 151-160.

Sneath, P.H.A., Sokal. R.R. (1973). Numerical Taxonomy. W. H. Freeman and Company, San Francisco.

Solem, A. (1959). Systematics and zoogeography of the land and freshwater Mollusca of the New Hebrides. Fieldiana, Zoology 43: 4-359.

Solem, A. (1974). The Shell Makers. John Wiley \& Sons, New York.

Solem, A. (1983). Endodontoid Land Snails from Pacific Islands (Mollusca: Pulmonata: Sigmurethra). Part II. Families Punctidae and Charopidae. Zoogeography. Field Museum of Natural History, Chicago.

Solem. A. (1984). A world model of land snail diversity and abundance. In A. Solem and A.C. van Bruggen (eds), World-wide Snails. Biogeographical Studies on Nonmarine Mollusca: 6-22. Brill/Backhuys, Leiden.

Solem, A. (1990). Limitations of equilibrium theory in relation to land snails. In Proceedings of an 'International Symposium on Biogeographical Aspects of Insularity', Rome, 18-22 May 1987. Atti Dei convegni Lincei 85: 97-116. Accademia Nazionale dei Lincei, Roma.

Solem, A. (1998). Superfamily Bulimuloidea. In P.L. Beesley, G.J.B. Ross and A. Wells (eds), Mollusca: The Southern Synthesis: 1093-1096. Fauna of Australia, Volume 5, Part B, CSIRO Pubishing, Melbourne.

Solem, A. and Climo, F.M. (1985). Structure and habitat correlations of sympatric New Zealand land snail species. Malacologia 26: 1-30.

Solem, A., Climo, F.M. and Roscoe, D.J. (1981). Sympatric species diversity of New Zealand land snails. New Zealand Journal of Zoology 8: 453-485.

Solem, A. and Yochelson, E.L. (1979). North American Paleozoic Land Snails, with a Summary of Other Paleozoic Nonmarine Snails: iii +42 pp, 10 pls. Geological Survey Professional Paper 1072, US Government Print Office, Washington.

Sommer, U. (1985). Comparison between steady state and non-steady state competition experiments with natural phytoplankton. Limnology and Oceanography 30: 335-346.

Spencer, H.G., Marshall, B.A. and Willan, R. C. (2005). Recent Mollusca. In D.P. Gordon (ed.), The New Zealand Inventory of Biodiversity: A Species 2000 Symposium Review. Canterbury University Press, Christchurch (in press).

Srivastava, D.S. (1999). Using local-regional richness plots 
to test for species saturation: pitfalls and potentials. Journal of Animal Ecology 68: 1-16.

Stanisic, J. (1998). Superfamily Pupilloidea. In P.L. Beesley, G.J.B. Ross and A. Wells (eds), Mollusca: The Southern Synthesis: 1082-1085. Fauna of Australia, Volume 5, Part B, CSIRO Pubishing, Melbourne.

Stevens, G.R. (1980). New Zealand Adrift. The Theory of Continental Drift in a New Zealand Setting. Reed, Wellington.

Stöckler, K, Daniel, I.L. and Lockhart, P.J. (2002). New Zealand kauri (Agathis australis (D. Don) Lindl., Araucariaceae) survives Oligocene drowning. Systematic Biology 51: 827-832.

Stewart, G.H. and Burrows, L.E. (1994). Coarse woody debris in old-growth temperate beech (Nothofagus) forests of New Zealand. Canadian Journal of Forest Research 24: 1989-1996.

Strong, D.R., Lawton, J.H. and Southwood, T.R.E. (1984). Insects on Plants: Community Patterns and Mechanisms. Blackwell, Oxford.

Suggate, R.P., Stevens, G.R. and Te Punga, M.T. (eds.) (1978). The Geology of New Zealand, Volumes I and II. Government Printer, Wellington.

Suh, Y., Thien, L.B., Reeve, H.E. and Zimmer, E.A. (1993). Molecular evolution and phylogenetic implications of internal transcribed spacer sequences of ribosomal DNA in Winteraceae. American Journal of Botany 80: 1042-1055.

Suter, H. (1913). Manual of New Zealand Mollusca. Government Printer, Wellington.

Sutherland, R. (1999). Basement geology and tectonic development of the greater New Zealand region: an interpretation from regional magnetic data. Tectonophysics 308: 341-362.

Symondson, W.O.C. (2004). Coleoptera (Carabidae, Staphylinidae, Lampyridae, Drilidae and Silphidae) as predators of terrestrial gastropods. In G.M. Barker (ed.), Natural Enemies of Terrestrial Molluscs: 37-84. CABI Publishing, Wallingford.

Tattersfield, P. (1996). Local patterns of land snail diversity in a Kenyan rain forest. Malacologia 38: 161180.

Thiele, J. (1929-1935). Handbuch der Systematischen Weichtierkunde. Volumes 1 and 2. Gustav Fischer, Jena.

Thompson, F.G. and Dance, S.P. (1983). Non-marine mollusks of Borneo. II Pulmonata: Pupillidae, Clausiliidae. III Prosobranchia: Hydrocenidae, Helicinidae. Bulletin of the Florida State Museum, Biological Sciences 29: 101-152.

Tillier, S. (1989). Comparative morphology, phylogeny and classification of land snails and slugs (Gastropoda: Pulmonata: Stylommatophora). Malacologia 30: 1-303.

Trewick, S.A. (2001). Scree weta phylogeography: surviving glaciation and implications for Pleistocene biogeography in New Zealand. New Zealand Journal of Zoology 28: 291-298.

Trewick, S.A. and Wallis, G.P. (2001). Bridging the "beech-gap": New Zealand invertebrate phylogeography implicates Pleistocene glaciation and Pliocene isolation. Evolution 55: 2170-2180.

Trewick, S.A., Wallis, G.P. and Morgan-Richards, M.
(2000). Phylogeographical pattern correlates with Pliocene mountain building in the alpine scree weta (Orthoptera, Anostostomatidae). Molecular Ecology 9: 657-666.

Veech, J.A., Summerville, K.S., Crist, T.O. and Gering, J.C. (2002). The additive partitioning of diversity: recent revival of an old idea. Oikos 99: 3-9.

Venables, W.N. and Ripley, B.D. (1997). Modern Applied Statistics with S-Plus. Springer, Berlin, Heidelberg, New York.

Wagner, H.H., Wildi, O., and Ewald, K.C. (2000). Additive partitioning of plant species diversity in an agricultural mosaic landscape. Landscape Ecology 15: 219-227.

Wagstaff, S.J. and Garnock-Jones, P.J. (1998). Evolution and biogeography of the Hebe complex (Scrophulariaceae) inferred from ITS sequences. New Zealand Journal of Botany 37: 425-437.

Wagstaff, S.J. and Wardle, P. (1999). Whipcord hebes systematics, distribution, ecology and evolution. New Zealand Journal of Botany 38: 17-39.

Walker, K. (2003). Recovery plans for Powelliphanta land snails 2003-2013. Threatened Species Recovery Plan No. 49: 1-208, 64 pls. Department of Conservation, Wellington.

Wardle, D.A., Barker, G.M., Yeates, G.W., Bonner, K.I. and Ghani, A. (2001). Introduced browsing mammals in New Zealand natural forests: aboveground and belowground consequences. Ecological Monographs 71: 587-614.

Wardle, D.A., Walker, L.R. and Bardgett, R.D. (2004). Ecosystem properties and forest decline in contrasting long-term chronosequences. Science 305: 509-513.

Wardle, P. (1963). Evolution and distribution of the New Zealand flora as affected by Quarternary climates. New Zealand Journal of Botany 1: 3-17.

Wardle, P. (1991). Vegetation of New Zealand. Cambridge University Press, Cambridge.

Wardle, P., Bulfin, M.J.A. and Dugdale, J. (1983). Temperate broad-leaved evergreen forests of New Zealand. In J.D. Ovington (ed.), Ecosystems of the World, 10: 33-71. Elsevier Scientific Publishing, Amsterdam.

Wellman, H.W. (1979). An uplift map for the South Island of New Zealand, and a model for uplift of the Southern Alps. In R.I. Walcott and M.M. Cresswell (eds), The Origin of the Southern Alps. Royal Society of New Zealand Bulletin No. 18: 13-20. Royal Society of New Zealand, Wellington.

Wellman, H.W. (1985). Evolution of the North Island during the last 32 million years. Newsletter of the Geological Society of New Zealand 68: 38-40.

Whittaker, R.H. (1965). Dominance and diversity in land plant communities. Science 147: 250-260.

Whittaker, R.H. (1972). Evolution and measurement of species diversity. Taxon 21: 213-251.

Williamson, M.H. (1988). Relationships of species number to area, distance and other variables. In A.A. Myers and P.S. Giller (eds), Analytical Biogeography: 91-115. Chapman and Hall, London.

Winkworth, R.C., Robertson, A.W., Ehrendorfer, F. and 
Lockhart, P.J. (1999). The importance of dispersal and recent speciation in the flora of New Zealand. Comment on M. Pole (1994): The New Zealand flora entirely long-distance dispersal? J. Biogeography 21, 625-635 and letter from M.K. Macphail (1997) J. Biogeography 24, 113-114. Journal of Biogeography 26: 1323-1325.

Winkworth, R.C., Wagstaff, S.J., Glenny, D. and Lockhart, P.J. (2002). Plant dispersal N.E.W.S from New Zealand. Trends in Ecology \& Evolution 17: 514520 . 